PNL-5595

UC-94c

\title{
SYSPLAN: \\ Model Documentation and Users' Guide
}

\author{
C. J. Hostick \\ R. A. Hutchinson \\ C. Winter
}

January 1986

Prepared for the U.S. Department of Energy under Contract DE-AC06-76RLO 1830

Pacific Northwest Laboratory Operated for the U.S. Department of Energy by Battelle Memorial Institute 


\title{
DISCLAIMER
}

This report was prepared as an account of work sponsored by an agency of the United States Government. Neither the United States Government nor any agency thereof, nor any of their employees, makes any warranty, express or implied, or assumes any legal liability or responsibility for the accuracy, completeness, or usefulness of any information, apparatus, product, or process disclosed, or represents that its use would not infringe privately owned rights. Reference herein to any specific commercial product, process, or service by trade name, trademark, manufacturer, or otherwise, does not necessarily constitute or imply its endorsement, recommendation, or favoring by the United States Government or any agency thereof. The views and opinions of authors expressed herein do not necessarily state or reflect those of the United States Government or any agency thereof.

\author{
PACIFIC NORTHWEST LABORATORY \\ operated by \\ BATTELLE \\ for the \\ UNITED STATES DEPARTMENT OF ENERGY \\ under Contract DE-AC06-76RLO 1830
}

\begin{tabular}{|c|c|}
\hline \multicolumn{2}{|c|}{ Printed in the United States of America } \\
\hline \multirow{2}{*}{\multicolumn{2}{|c|}{$\begin{array}{c}\text { Available from } \\
\text { National Technical Information Service }\end{array}$}} \\
\hline & \\
\hline \multicolumn{2}{|c|}{$\begin{array}{l}\text { National Technical Information Service } \\
\text { United States Department of Commerce }\end{array}$} \\
\hline \multicolumn{2}{|c|}{ Springfield, Virginia 22161} \\
\hline \multirow{2}{*}{\multicolumn{2}{|c|}{$\begin{array}{l}\text { NTIS Price Codes } \\
\text { Microfiche } A 01\end{array}$}} \\
\hline & \\
\hline \multicolumn{2}{|c|}{ Printed Copy } \\
\hline & Price \\
\hline Pages & Codes \\
\hline 001-025 & $\mathrm{A} 02$ \\
\hline $026-050$ & $\mathrm{~A} 03$ \\
\hline $051-075$ & AOA \\
\hline $076-100$ & A05 \\
\hline $101-125$ & A06 \\
\hline $126-150$ & $\mathrm{~A} 07$ \\
\hline 151.175 & A08 \\
\hline $176-200$ & A09 \\
\hline $201-225$ & A010 \\
\hline 226-250 & A011 \\
\hline $251-275$ & $\mathrm{~A} 012$ \\
\hline $276-300$ & $A 013$ \\
\hline
\end{tabular}


PNL -5595

UC $-94 \mathrm{C}$

SYSPLAN: MODEL DOCUMENTATION

AND USERS' GUIDE
C. J. Hostick
R. A. Hutchinson
C. Winter

January 1986

Prepared for the U.S. Department of Energy under Contract DE-AC06-76RLO 1830

Pacific Northwest Laboratory

Richland, Washington 99352 


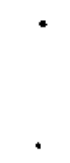

、

- 
This report describes software designed to evaluate capital investment in customer-side-of-the-meter load leveling battery systems. The microcomputerbased software was developed at the Pacific Northwest Laboratory (PNL), which is operated by Battelle Memorial Institute for the U.S. Department of Energy (DOE). Load leveling battery systems reduce a customer's monthly electrical demand charge by reducing the maximum power load supplied by the utility during the customer's peak demand. The system consists of a large array of batteries, a converter that changes $A C$ current into $D C$ current (or $D C$ current into $A C$ current), and balance-of-plant equipment and facilities required to support the battery and converter system. Using the software described in this report, the economic feasibility of load leveling systems can easily be evaluated to determine if more detailed studies are warranted. 


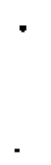

• 


\section{CONTENTS}

SUMMARY

$i i i$

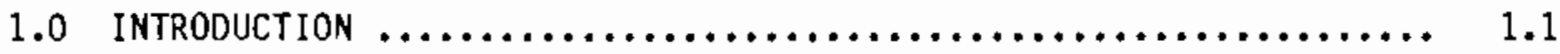

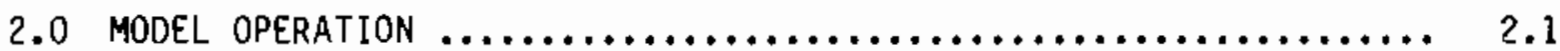

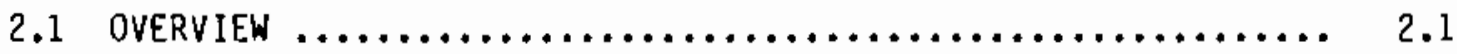

2.2 XSIZE SYSTEM SIZING ROUTINE $\ldots \ldots \ldots \ldots \ldots \ldots \ldots \ldots \ldots \ldots \ldots \ldots$

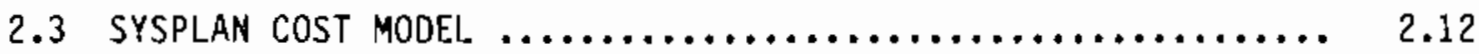

3.0 DESCRIPTION OF INPUT AND OUTPUT TERMS $\ldots \ldots \ldots \ldots \ldots \ldots \ldots \ldots \ldots . . \ldots \ldots$

3.1 XSIZE SIZING MODEL INPUT/DUTPUT TERMS $\ldots \ldots \ldots \ldots \ldots \ldots \ldots \ldots .3 .1$

3.2 COST MODEL INPUT/OUTPUT TERMS $\ldots \ldots \ldots \ldots \ldots \ldots \ldots \ldots \ldots \ldots \ldots \ldots \ldots \ldots$

APPENDIX A - MODEL VERIFICATION $\ldots \ldots \ldots \ldots \ldots \ldots \ldots \ldots \ldots \ldots \ldots \ldots \ldots \ldots \ldots \ldots \ldots \ldots \ldots$

APPENDIX B - TECHNICAL DOCUMENTATION FOR XSIZE SIZING MODEL ....... B. 1

APPENDIX C - TECHNICAL DOCUMENTATION FOR SYSPLAN COST MOOEL ........ C.I 
.

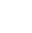




\section{FIGURES}

1.1 Diagram of Customer-Side Load Leveling Battery System $\ldots \ldots \ldots \ldots .1 .1$

1.2 Illustration of the Impact of a Load Leveling Battery System on a Customer's Power Load ................................ 1.2

2.1 General Layout of SYSPLAN Moder $\ldots \ldots \ldots \ldots \ldots \ldots \ldots \ldots \ldots \ldots .2 .2$

2.2 General Layout of XSIZE Model $\ldots \ldots \ldots \ldots \ldots \ldots \ldots \ldots \ldots \ldots \ldots, 2.4$

2.3 Menu Description of Battery System Economics $\ldots \ldots \ldots \ldots \ldots \ldots \ldots .2 .6$

2.4 Example of Battery Load-Leveling $\ldots \ldots \ldots \ldots \ldots \ldots \ldots \ldots \ldots \ldots, 2.7$

2.5 Example of Battery Load-Leveling $\ldots \ldots \ldots \ldots \ldots \ldots \ldots \ldots \ldots \ldots, 2.8$

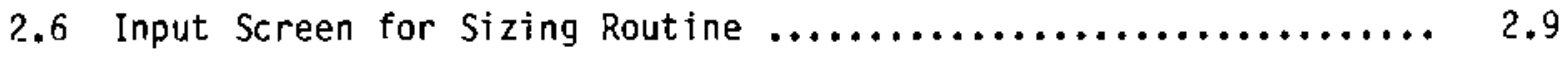

2.7 Example Sizing Routine Size Range Estimate $\ldots \ldots \ldots \ldots \ldots \ldots \ldots . . .2 .9$

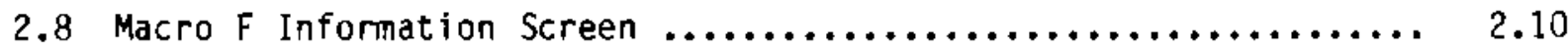

2.9 Macro 0 Utility Change and Battery Operating

2.10 SYSPLAN Spreadsheet Layout $\ldots \ldots \ldots \ldots \ldots \ldots \ldots \ldots \ldots \ldots \ldots \ldots \ldots \ldots \ldots \ldots \ldots \ldots \ldots \ldots, 2.13$

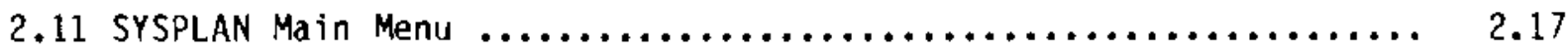

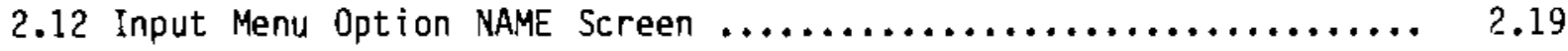

2.13 Input Menu Option UCHARGE Screen $\ldots \ldots \ldots \ldots \ldots \ldots \ldots \ldots \ldots \ldots, 2.21$

2.14 Input Menu Option OPERATING Screen $\ldots \ldots \ldots \ldots \ldots \ldots \ldots \ldots \ldots \ldots, 2.22$

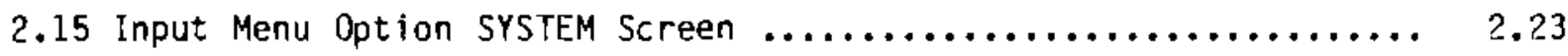

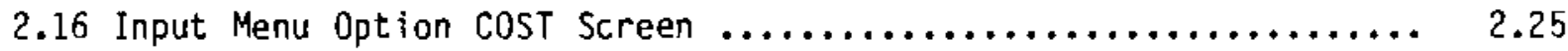

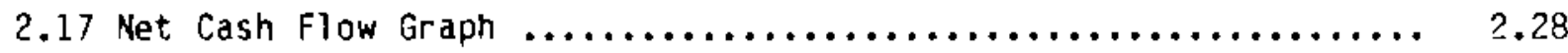

2.18 Cash Flow Graph $\ldots \ldots \ldots \ldots \ldots \ldots \ldots \ldots \ldots \ldots \ldots \ldots \ldots \ldots \ldots, 2.28$

2.19 Battery System Description Report $\ldots \ldots \ldots \ldots \ldots \ldots \ldots \ldots \ldots \ldots \ldots .2 .31$

2.20 Economic Analysis Summary Report $\ldots \ldots \ldots \ldots \ldots \ldots \ldots \ldots \ldots \ldots . \ldots \ldots . . .32$

2.21 Sensitivity Analysis Screen $\ldots \ldots \ldots \ldots \ldots \ldots \ldots \ldots \ldots \ldots \ldots \ldots, 2.34$ 
2.22 Sensitivity Analysis Report $\ldots \ldots \ldots \ldots \ldots \ldots \ldots \ldots \ldots \ldots \ldots \ldots \ldots \ldots$

2.23 Example Menu Option WORTH Graph of Present Worth Versus

Expected Battery Life .............................. 2.38

2.24 Example Menu Option GPAYBACK Graph of Payback Period Versus

Expected Battery Life .............................. 2.39

2.25 Example Summary of Key Economic Performance Measures .......... 2.40 
TABLES

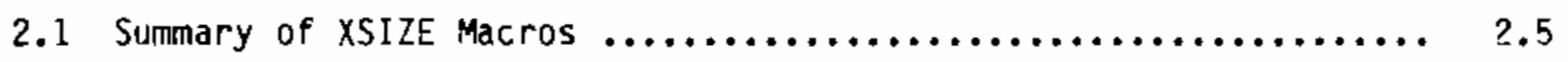

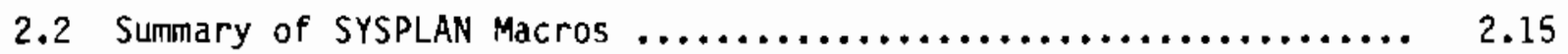




\subsection{INTRODUCTION}

This document describes software designed to evaluate capital investment in customer-side-of-the-meter load leveling battery systems. The purpose of a load leveling battery system is to reduce a customer's monthly electrical demand charge by reducing the maximum power load supplied by the utility during the customer's peak demand.

Load leveling battery system equipment consists of a large array of batteries, a converter that changes $A C$ current into $D C$ current (or $D C$ current into $A C$ current), and balance-of-plant equipment and facilities required to support the battery and converter system. A diagram of a load leveling system is shown in Figure 1.1.

The impact of a load leveling battery system on a customer's power load is shown in Figure 1.2. The system is installed on the customer's side of the meter and is controlled and operated by the customer. The battery system charges during a customer's off-peak power requirement periods and discharges

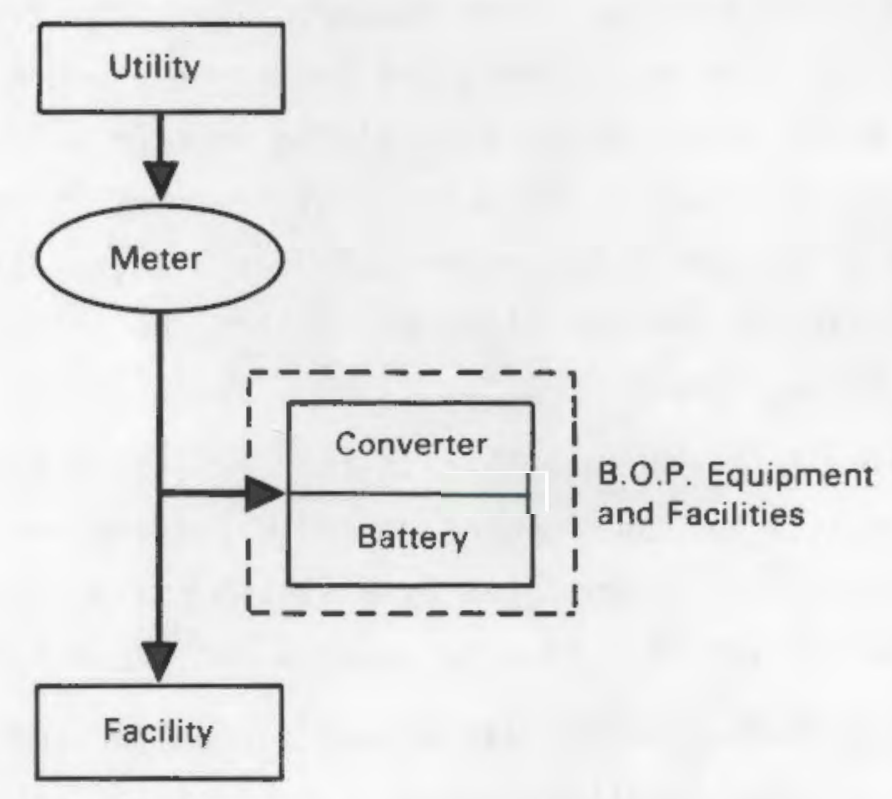

FIGURE 1.1. Diagram of Customer-Side Load Leveling Battery System 


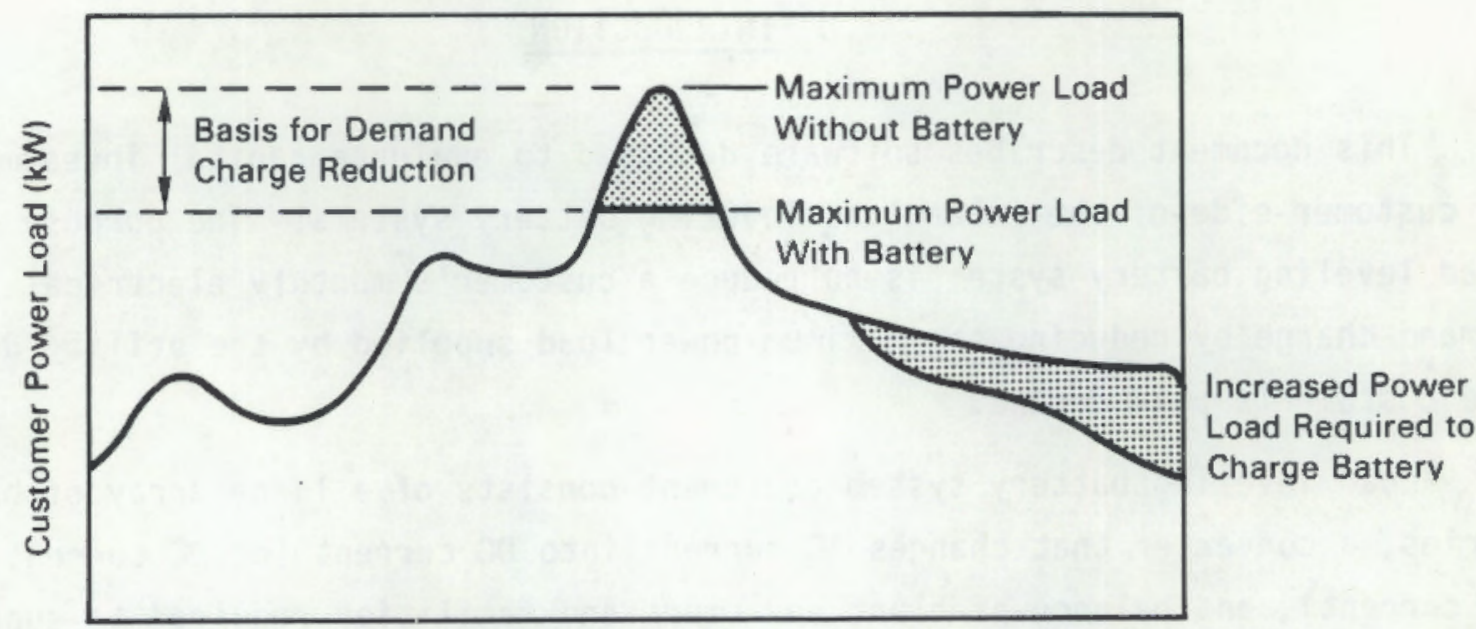

Time of Day

FIGURE 1.2. Illustration of the Impact of a Load Leveling Battery System on a Customer's Power Load

during the customer's peak demand periods. The economic feasibility of a load leveling battery system depends largely on the customer's load profile. Because the primary economic benefit of load leveling is a reduction in a customer's monthly demand charge, only those customers with significant demand peaks will find a load leveling system economically attractive. Load shape requirements, utility rate structures, and battery equipment cost and performance information serve as bases for determining whether a load leveling battery system is economically feasible for a particular installation. Life-cycle costs for load leveling system hardware include all costs associated with the purchasing, installation, and operation of battery, converter, and balance-ofplant facilities and equipment.

The spreadsheet software described in this report is specifically designed to evaluate these costs and the reduced demand charge benefits. The life-cycle cost analysis spreadsheet is augmented by a system sizing routine to help users identify load leveling system size requirements for their facilities.

In summary, the software provides a tool for performing scoping studies of the applicability of load leveling systems for specific facilities. This 
analysis package is not a complete investment analysis, but rather a first step toward perfoming detailed engineering feasibility studies.

Chapter 2.0 of this report describes the three spreadsheet files that make up the load leveling system analysis software, including their operation and various macro programs. Chapter 3.0 contains definitions of the various terms used in the software. Finally, model verification and technical documentation are provided in the Appendices. 


\subsection{MODEL OPERATION}

The load leveling system analysis software package described in this report consists of three spreadsheet files: XSIZE, SIZE, and SYSPLAN. The main life-cycle cost model is contained in the SYSPLAN spreadsheet file. A general layout of the SYSPLAN model is provided in Figure 2.1. The file XSIZE is an optional battery system sizing routine designed to help users identify load-leveling system requirements for their facilities. The output of XSIZE identifies the load-leveling system operating requirements; this information is then passed by the temporary file SIZE to the main SYSPLAN spreadsheet. These spreadsheet files are described in the following sections.

\subsection{OVERVIEW}

The preliminary economic analys is of customer-side-of-the-meter battery systems is completed by using the SYSPLAN spreadsheet. This spreadsheet completes a 20-year period life-cycle cost analysis based on the battery system description and cost data. The optional sizing routine, XSIZE, can be used to identify a range of battery system sizes that might be economically attractive.

The SYSPLAN and XSIZE spreadsheets have been developed with the Lotus123 software package. The third spreadsheet file, SIZE, is a temporary file used only to transfer information from XSIZE to SYSPLAN. To run SYSPLAN and the sizing routine, a user needs an IBM-PC with at least $256 \mathrm{~K}$ of interna? memory and two floppy disk drives (or one floppy disk drive and one hard disk Jrive). In addition, a copy of the Lotus 123 software is needed to access the two spreadsheets.

Lotus 123, the software with which the SYSPLAN model was developed, is a spreadsheet software copyrighted by the Lotus Development Corporation. The following Lotus 123 tems are used in this manual:

- Macro

- Pointer

- Cell

- Cursor-Movement Keys

The carriage return key is referred to as <RETURN>. The escape key is indicated by $\langle E S C\rangle$. 


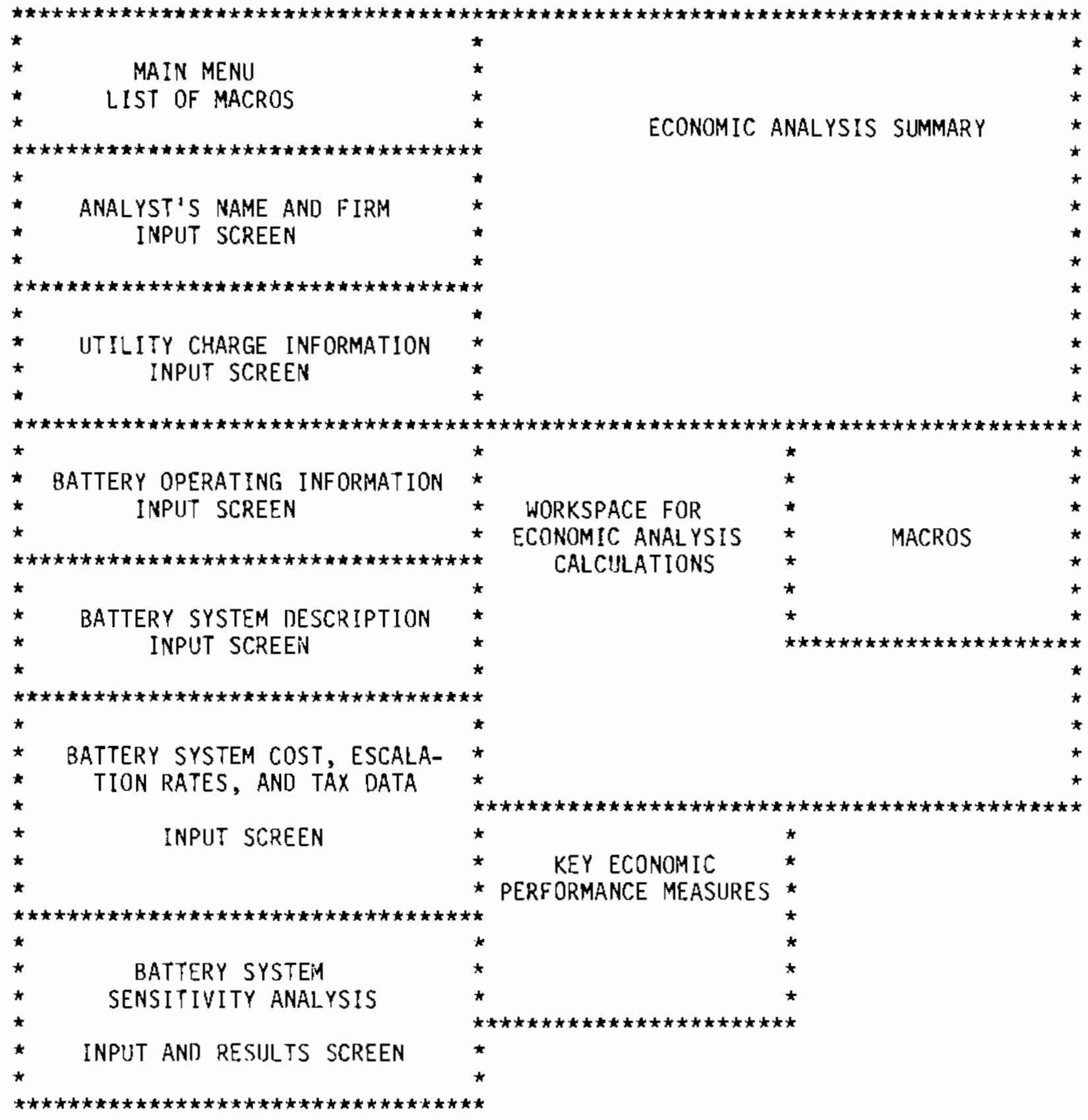

FIGURE 2.1. General Layout of SYSPLAN Model 
The instructions for using SYSPLAN and the sizing routine XSIZE describe all operations specific to these spreadsheets. It is assumed, however, that users have some familiarity with the operation of Lotus123. Specifically, you should know how to access Lotus 123 and retrieve spreadsheets, how to set up your printer for use with Lotus123, and how to use the Lotus Print Graph program to obtain hard copy of Lotus 123 graphs. If you are unfamiliar with these operations, consult the Lotus 123 manual (1983, Lotus Development Corp.), the on-line tutorial, or an experienced Lotus 123 user before using SYSPLAN.

If you begin to use SYSPLAN and the sizing routine XSIZE a great deal for analysis tasks, you may wish to change these spreadsheets. For this reason, documentation of the spreadsheets' formulas, cell protection schemes and macro programs has been provided in Appendix $B$ for the XSIZE sizing routine and in Appendix $C$ for the main spreadsheet. Experienced Lotus 123 users can use the appendices as an aid to changing the spreadsheets for particular applications.

Section 2.2 contains details for using the optional sizing routine, XSIZE. Section 2.3 provides step-by-step instructions for using the SYSPLAN spreadsheet.

\subsection{XSIZE SYSTEM SIZING ROUTINE}

The XSIZE system sizing routine is an optional program primarily designed to introduce the concept of load leveling using battery storage. This program helps users make initial choices about suitable battery storage applications and preliminary battery system sizes. The output consists of relevant battery operating data and utility rate information that can be loaded automatically into the life-cycle cost analysis spreadsheet SYSPLAN.

The XSIZE spreadsheet includes several simple macro prograns to speed operation. These macros and their purposes are listed below, along with the Lotus 123 commands you will use. Figure 2.2 shows how the spreadsheet is organized. Table 2.1 summarizes the macros used in XSIZE and shows the page number where each macro is discussed. 


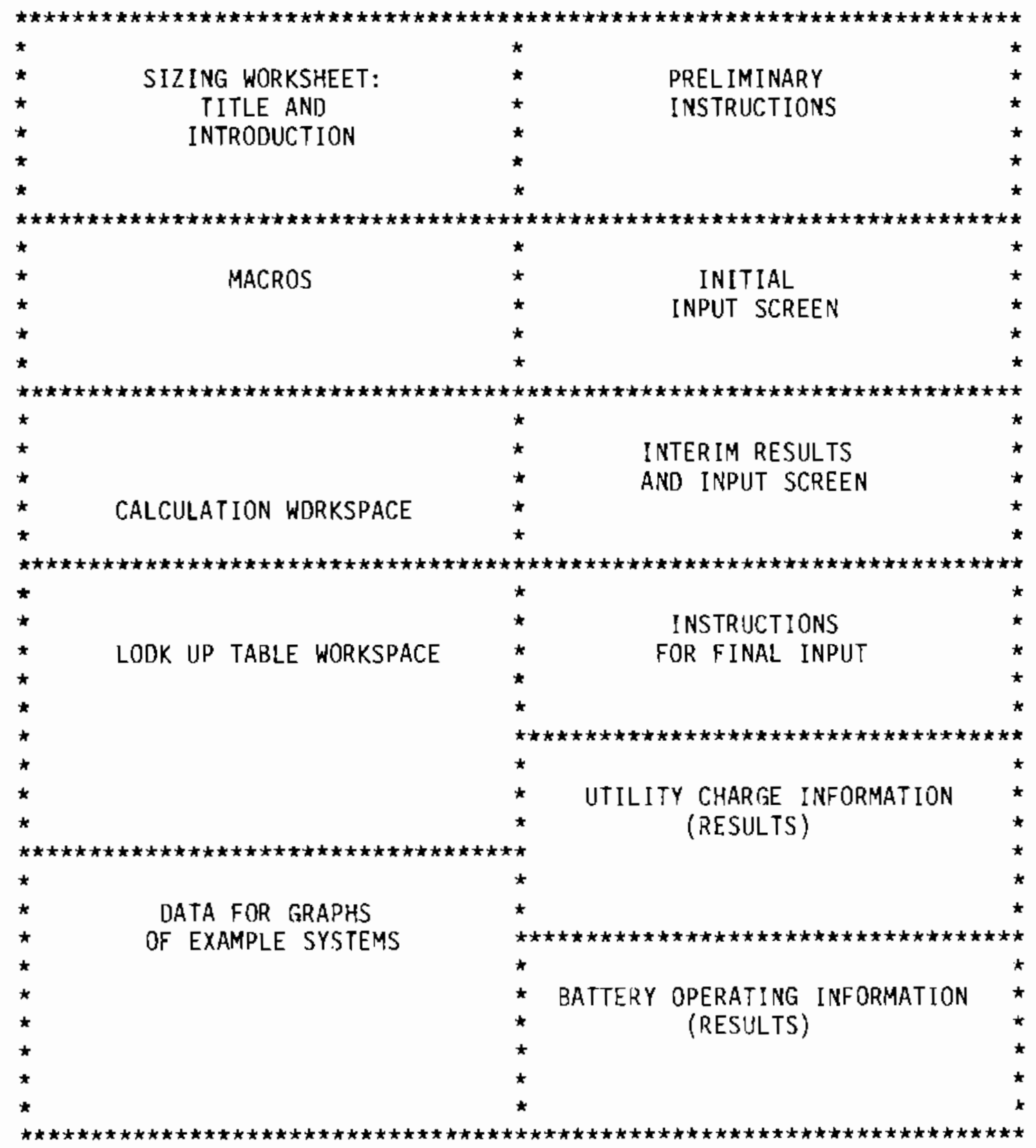

FIGURE 2.2. General Layout of XSIZE Model 
TABLE 2.1. Summary of XSIZE Macros

Macro Programs

See Page

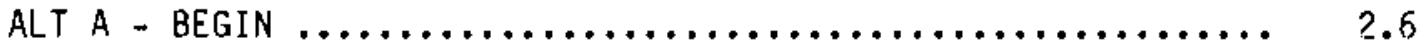

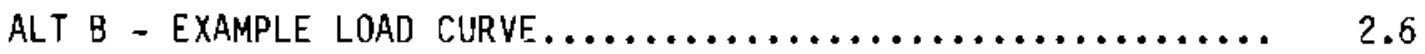

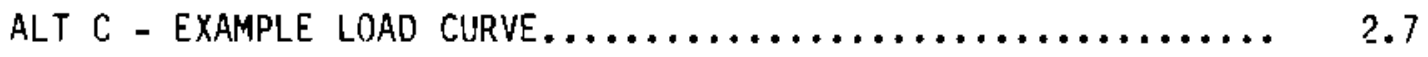

ALT D - INPUT DATA TO ESTIMATE A BATTERY SYSTEM SIZE RANGE.... 2.7

ALT E - CALCIJLATE SIZE RANGE ESTIMATE................ 2.8

ALT $F-$ CONTINUE. ............................ 2.8

ALT 0 - CREATE AND VIEW OUTPUT FILE.................. 2.10

ALT $P$ - CREATE PASS FILE SIZE CONTAINING OUTPUT FILE........ 2.12

\section{Lotus 123 Commands Used in XSIZE}

/fr (File Retrieve) XSIZE - Load XSIZE model into Lotus 123

10 (Quit) - Leave Lotus 123 , cursor movement, data entry

Order of Execution

- Get into Lotus 123 and retrieve XSIZE (/fr)

- ALT B - begin sizing routine

- ALT C - to calculate preliminary range of limiting sizes based on economic considerations

- ALT D, ALT E - to view examples of electric load curves and choices of applicable battery system size

- ALT F - to return from graphs

- ALT 0 - to set up battery system specifications and other information to be passed to SYSPLAN

- ALT P - to create pass file SIZE

- /q to quit

- in case of trouble, hit the 〈ESCAPE> key and then the 〈HDME> key to return to start of routine

/fr (File Retrieve) XSIZE - Load XSIZE model into Lotus 123 
This Lotus 123 command Joads XSIZE onto the computer's screen and into its internal memory. Before the command can be given, Lotus 123 must be loaded and a blank spreadsheet displayed on the screen. If you are unsure how to do this, consult a Lotus123 manual.

The exact command sequence is:

$$
\text { /fr XSIZE (return) }
$$

ALT A - Begin

\section{Press the ALT key and A key simultaneously}

This macro command displays the menu describing battery system economics shown by Figure 2.3. The information presented in this menu and the examples of peak shaving by battery systems serve as a tutorial explaining system benefits.

ALT-B - Example Load Curve

Press the ALT key and B key simultaneously

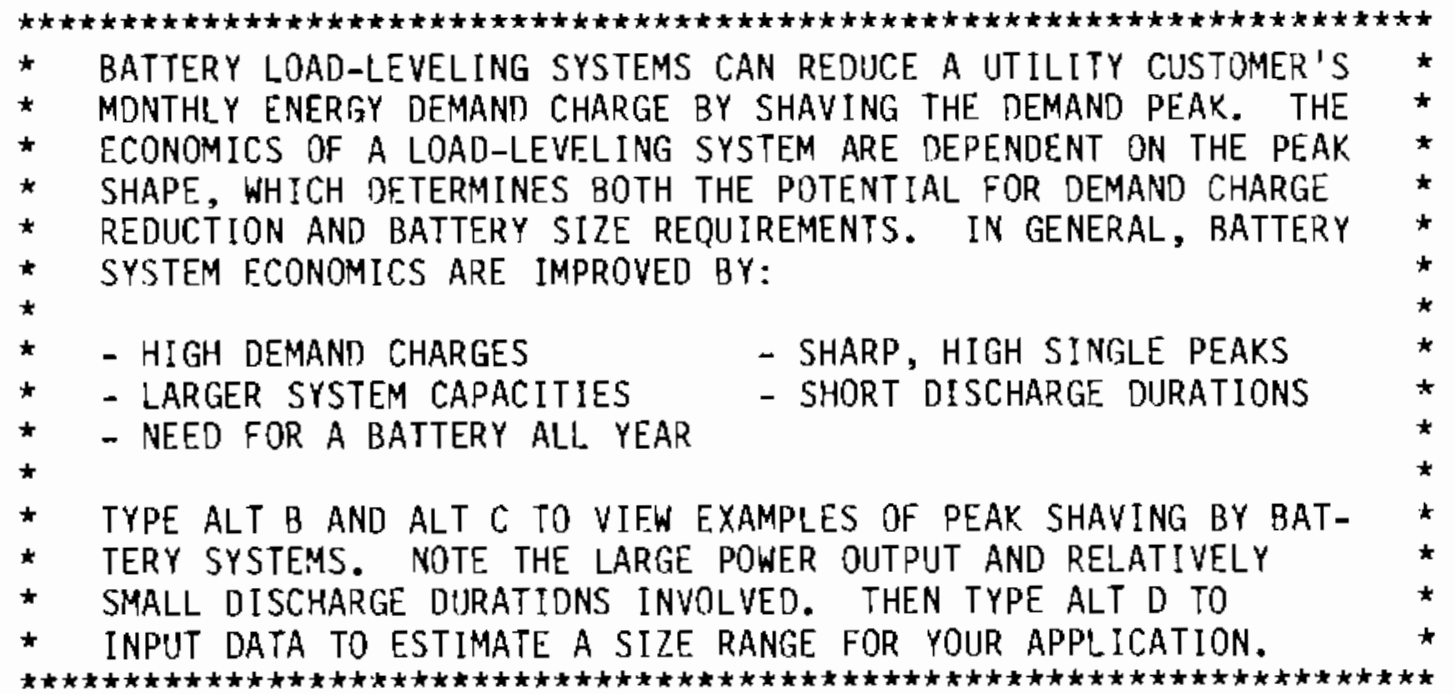

FIGURE 2.3. Menu Description of Battery System Economics 
Selecting this macro command displays the example of battery load-leveling shown in Figure 2.4.

ALT-C Example Load Curve

Press the ALT key and C key simultaneously

Selecting this macro displays the example of battery load-leveling shown in Figure 2.5.

ALT-D - Input Data to Estimate a Battery System Size Range

Press the ALT key and D key simultaneously

This macro command displays a screen that requests basic load and utility information, as shown in Figure 2.6. The 〈ESCAPE〉 key must be selected before the next macro is invoked.

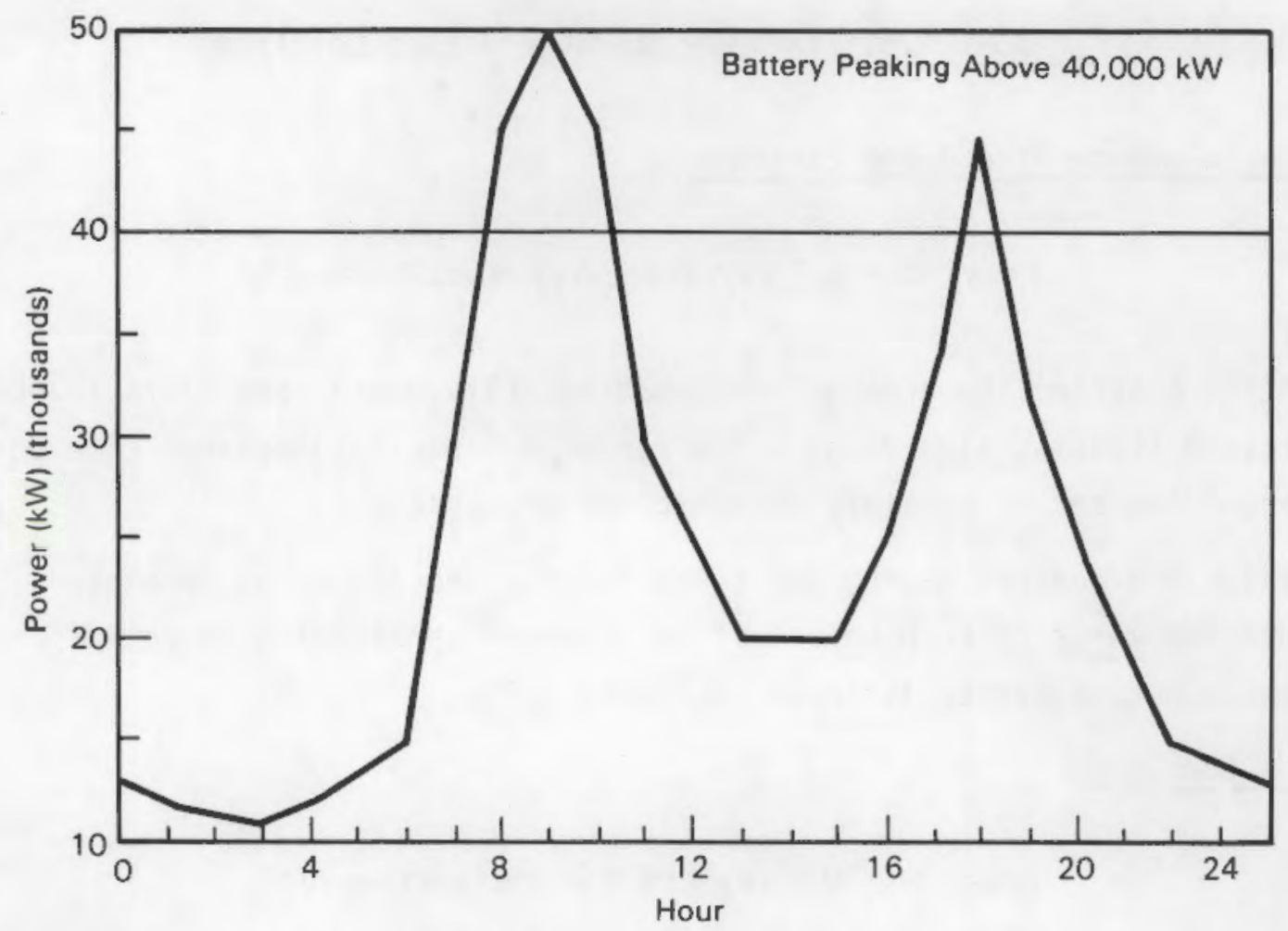

FIGURE 2.4. Example of Battery Load Leveling 


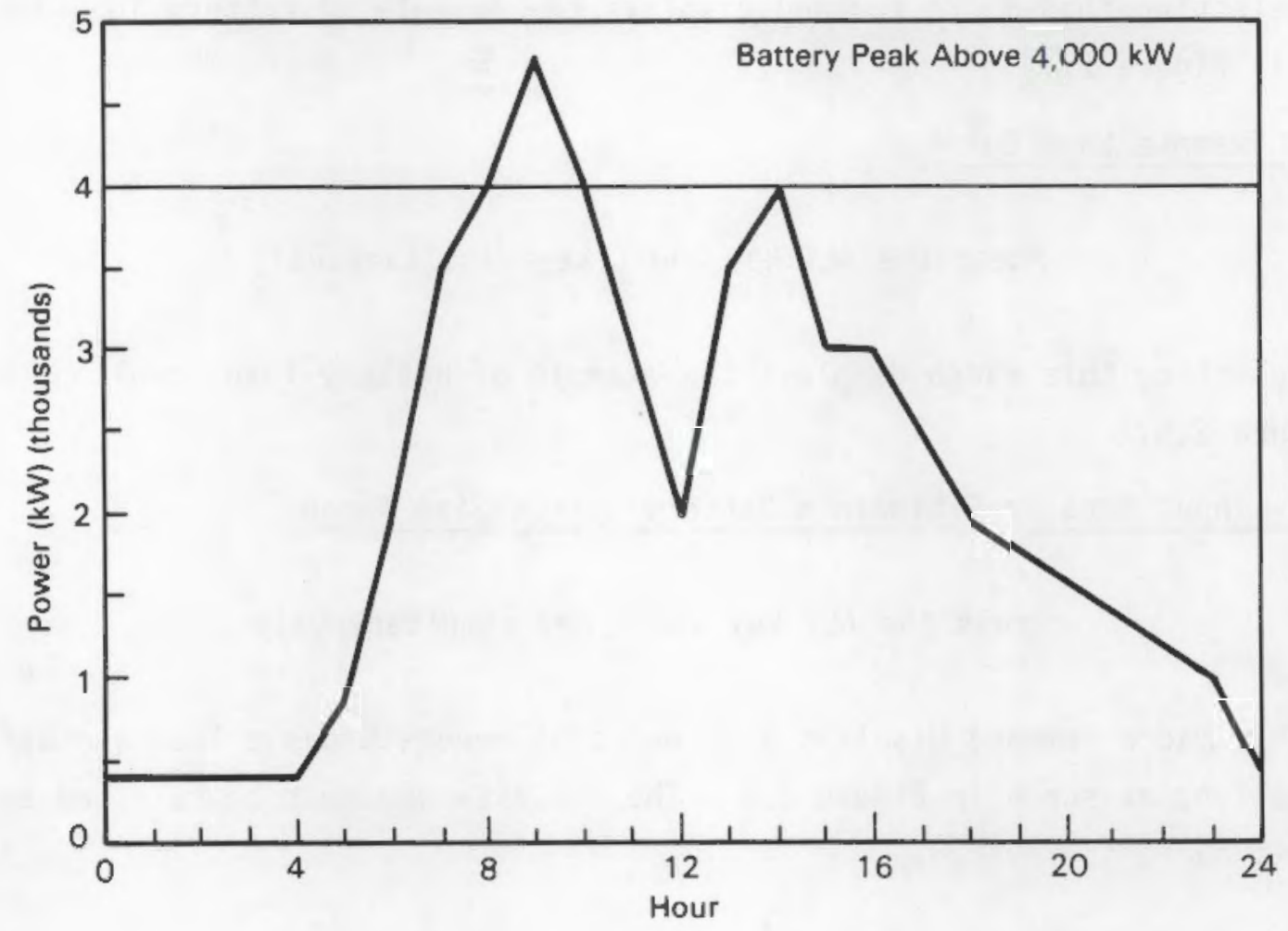

FIGURE 2.5. Example of Battery Load-Leveling

\section{ALT-E - Calculate Size Range Estimate}

Press the ALT key and E key simultaneousily

After entering the economic information, this macro command is invoked to calculate a limiting size range - the range of capacity/discharge time pairs that bound the set of possibly economic battery systems.

This is a complex macro, and takes several seconds to be completed. It will produce zeros ( $0 \mathrm{kw}-0$ hours) if no economic application is anticipated. An example output screen is shown in Figure 2.7 . ALT-F - Continue

Press the ALT key and F key simultaneously 


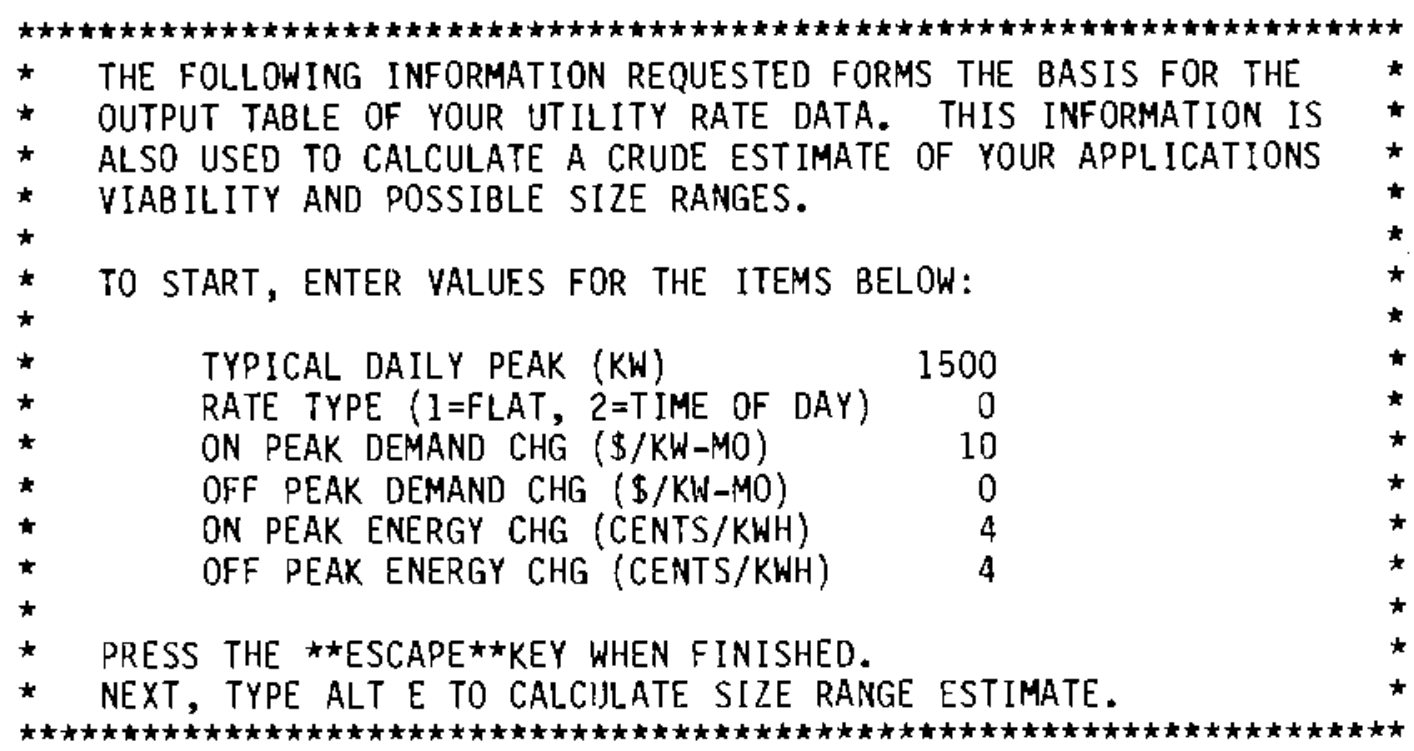

FIGURE 2.6. Input Screen for Sizing Routine

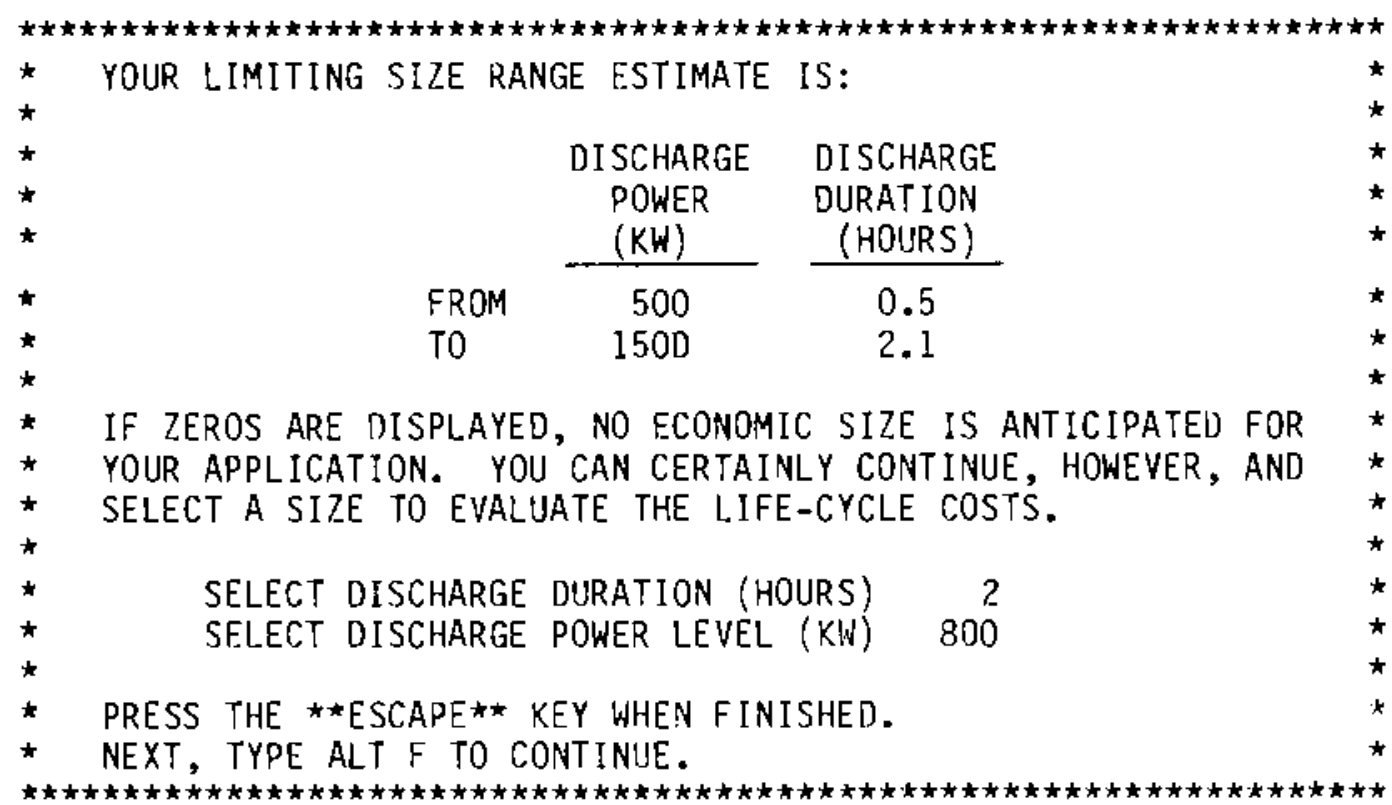

FIGURE 2.7. Example Sizing Routine Size Range Estimate

Selecting this macro displays a screen (shown in Figure 2.8) describing how a table of utility charge information and battery operating information is prepared for the life-cycie cost analysis. 


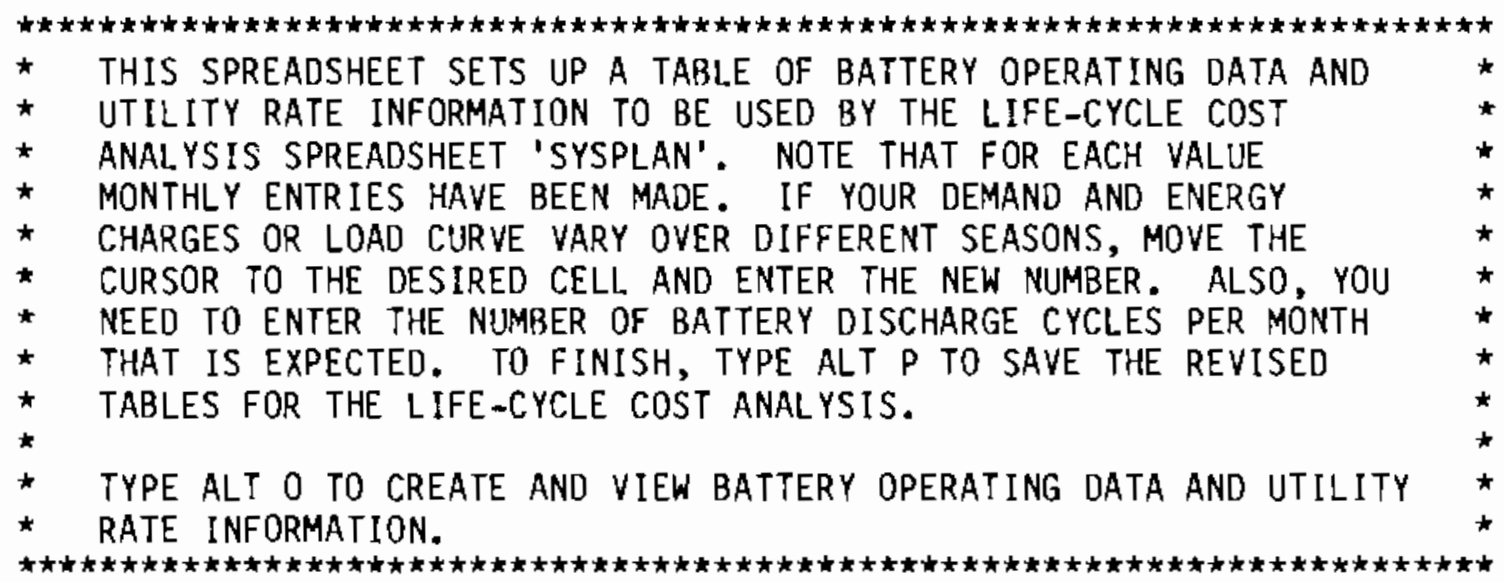

\title{
FIGURE 2.8. Macro F Information Screen
}

ALT -0 - Create and View Output File

\author{
Press the ALT key and 0 key simultaneously
}

This macro prepares the utility charge and battery operating information, as shown in Figure 2.9.

This macro contains all the commands necessary to set up preliminary battery system and economic specifications. This takes several seconds and involves considerable cursor movement on the screen.

Press ALT-0

Once you have set up this preliminary set of data, you can change the numbers in any way you wish. This is necessary if you have seasonal rate or operational changes, for instance. Note as well that you should input the number of cycles the battery will operate in a given month, as it is not specified by $\mathrm{ALT}-0$.

If you feel that you have made an error and wish to return the data set to its original state, you can press ALT-0 again. You can even go back and change data from earlier steps, using $A L T-B$ and $A L T-C$ and $A L T-F$ again. Be sure the data are exactly as you wish before moving on to the next step. 


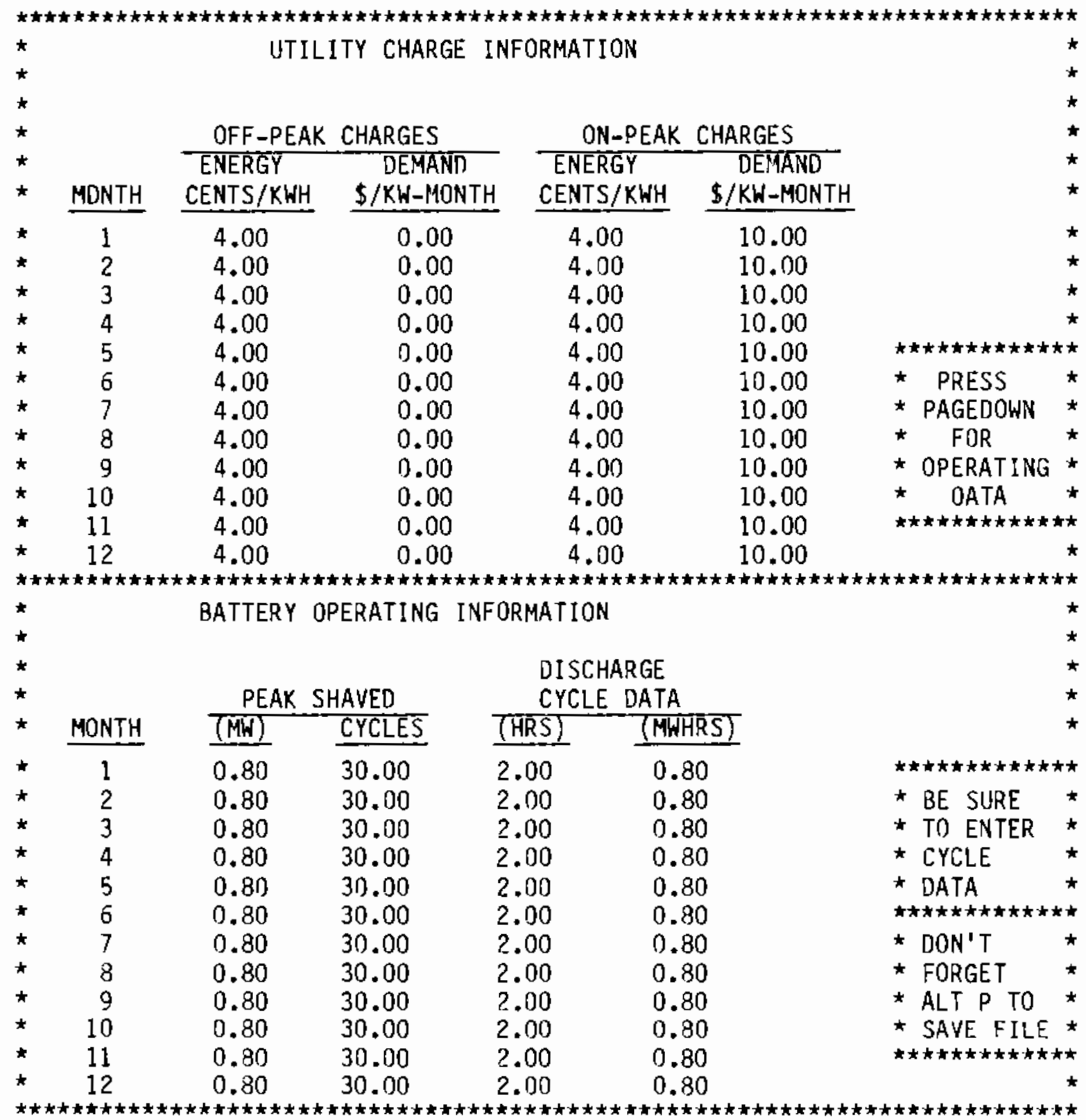

FIGURE 2.9. Macro 0 Utility Change and Battery Operating Information Tables 
ALT-P Create Pass File Size Containing Output File

Press the ALT key and P key simultaneously

Selecting this macro saves the tables shown by Figure 2.9 for the 1 ifecycle cost analysis.

This macro makes a small file of the data you have just completed specifying, including any changes you made after the ALT-0 command was given.

Press ALT-P

The pass file, called SIZE, can be retrieved from the SYSPLAN worksheet. This is done as one of the input options (the RETRIEVE option) of SYSPLAN's ALT-A Input Menu.

To exit from the XSIZE sizing routine use the following command:

/Q - Teave XSIZE battery system size specification spreadsheet.

\subsection{SYSPLAN COST MODEL}

The SYSPLAN model calculates the life-cycle costs of the load-leveling battery system. This program translates the system operating description and cost information into the iffe-cycle costs of the system. A built-in sensitivity analysis package is also included for key battery cost parameters. Results are presented in both tabular and graphical form. Figure 2.10 shows the spreadsheet layout. Table 2.2 summarizes the macros used in SYSPLAN and shows the page where each macro is discussed. These macros and their purposes are listed below, along with Lotus 123 commands you will use.

Ifr (File Retrieve) SYSPLAN - Load the SYSPLAN model into Lotus 123. 


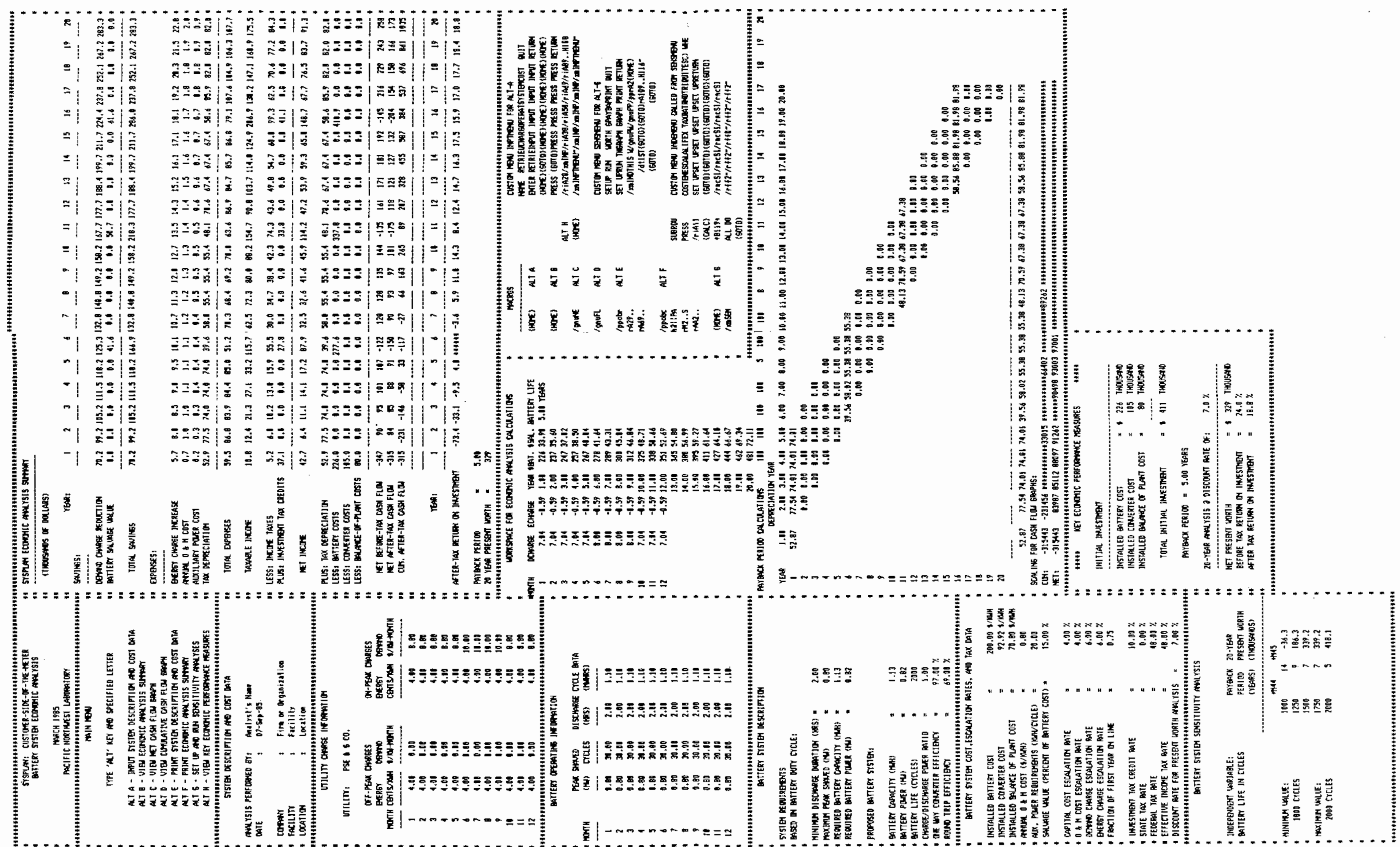



TABLE 2.2. Summary of SYSPLAN Macros

Macro Programs Used in SYSPLAN

See Page

ALT A - INPUT SYSTEM DESCRIPTION AND COST DATA............... 2.16

Displays the Input Menu, which has the following options:

NAME - ENTER YOUR NAME AND FIRM

RETRIEVE - RETRIEVE UTILITY CHARGE, OPERATING DATA FROM SIZING FILE

IJCHARGE - INPUT UTILITY CHARGE INFORMATION

OPERATING - INPUT BATTERY OPERATING INFORMATION

SYSTEM - INPUT UTILITY SYSTEM DESCRIPTION

COST - INPUT SYSTEM COST, ESCALATION RATES AND TAX DATA

QUIT - RETURN TO MAIN MENU

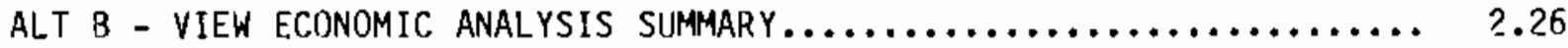

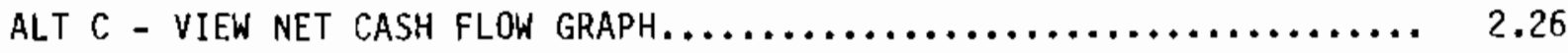

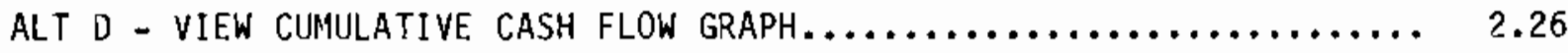

ALT E - PRINT SYSTEM DESCRIPTION AND COST DATA............... 2.29

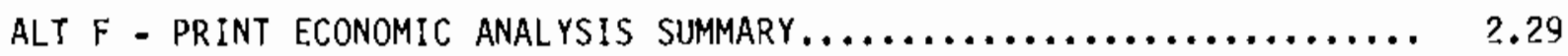

ALT G - SET UP AND RUN SENSITIVITY ANALYSES $\ldots \ldots \ldots \ldots \ldots \ldots \ldots \ldots \ldots \ldots . \ldots \ldots$

Displays the Analysis Menu, which has the following options:

SETUP - SETUP AN INDEPENDENT VARIABLE (FIVE CHOICES): COST, ESCALATION, LIFE, TAXRATE, ROUNDTRIP EFFICIENCY

RUN - RUN THE ANALYSIS WITH THE VARIABLE AND VALUES DISPLAYED ON SCREEN

WORTH - GRAPH PRESENT WORTH AGAINST INDEPENDENT VARIABLE SHOWN GPAYBACK - GRAPH PAYBACK PERIOD AGAINST INDEPENDENT VARIABLE SHOWN

PRINT - PRINT THE ANALYSIS RESULTS

QUIT - RETURN TO MAIN MENU

Al. $\mathrm{H}$ - VIEW KEY ECONOMIC PERfORMANCE MEASURES............... 2.38 
This Lotus 123 command is used to load the SYSPLAN model onto the computer's screen and into its internal memory. Before it can be issued, Lotus123 must be loaded and a blank spreadsheet displayed onscreen. If you are unsure how to do this, consult a Lotus 123 manual.

To load the SYSPLAN model, use the Lotus File Retrieve command:

\section{/ frSYSPLAN <RETURN>}

It does not matter whether SYSPLAN is entered with upper-case or lower-case letters. If the command is successful, SYSPLAN's Main Menu will be displayed onscreen, as shown in Figure 2.11. You are now ready to enter information describing a battery system.

The SYSPLAN spreadsheet includes several macro programs designed to ease the process of specifying and analyzing load-leveling battery systems. These macros and their purposes are described below, along with some common Lotus 123 commands you will use.

Lotus 123 Commands Used in SYSPLAN

/fr (File Retrieve) SYSPLAN - Load the SYSPLAN model into Lotus

Fg (CALC key) - Run the case most recently input

/gs (Graph Save) - Save a graph to file for printing/q (Quit) - Leave Lotus 123

〈HOME> - Home key returns to main menu

Order of Execution

- Access Lotus 123 and retrieve SYSPLAN (/fr)

- ALT A - input system description for a system scenario

- Fg (CALC) to run the case

- ALT B,C,D,E,F,H to view the output

- Igs to save graphs to disk

- ALT G to run sensitivity analyses

- /q to quit

- in case of trouble, hit the 〈ESCAPE> key and then the 〈HOME〉 key to return to the main menu 


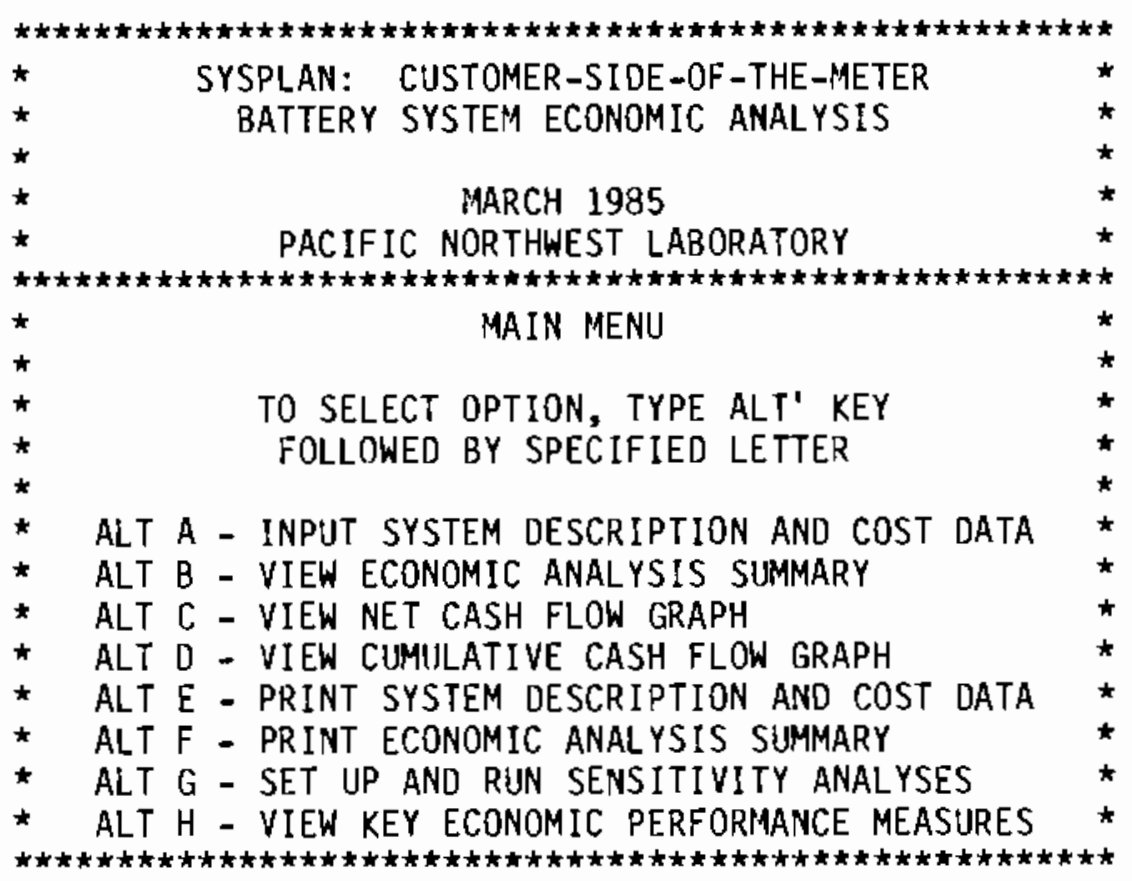

FIGURE 2.11. SYSPLAN Main Menu

ALT A - Input System Description and Cost Data

This macro command is executed in order to enter infomation describing a battery system. ALT A should be used before running a case or looking at output.

To begin the process of entering a battery system description, press the ALT key and the letter A simultaneously. A menu will appear at the top of the screen. This menu, called the Input Menu, offers the seven options listed below:

\begin{tabular}{|c|c|}
\hline Option & Description \\
\hline NAME & ENTER YOUR NAME AND FIRM \\
\hline RETR IEVE & $\begin{array}{l}\text { RETRIEVE UTILITY CHARGE, OPERATING DATA FROM } \\
\text { SIZING FILE }\end{array}$ \\
\hline UCHARGE & INPUT UTILITY CHARGE INFORMATION \\
\hline OPERATING & INPUT BATTERY OPERATING INFORMATION \\
\hline SYSTEM & INPUT UTILITY SYSTEM DESCRIPTION \\
\hline $\cos T$ & INPUT SYSTEM COST, ESCALATION RATES AND TAX DATA \\
\hline QUIT & RETURN TO MAIN MENU \\
\hline
\end{tabular}


The NAME, UCHARGE, DPERATING, SYSTEM and COST options each allow one kind of information about the battery system to be entered. The RETRIEVE option reads utility charge and operating data from the XSIZE sizing worksheet output file. It can be used along with options UCHARGE and OPERATING. To describe a battery system fully, the NAME, SYSTEM, COST, UCHARGE and OPERATING options should be chosen (RETRIEVE is optional). After each option is finished, the pointer returns to the Input Menu so that the next option may be selected. After all descriptive information has been entered, choose the QUIT option to erase the Input Menu from the top of the screen and return to the Main Menu.

An option can be selected in either of two ways. One way is to type the first letter of the option. For example, to choose the SYSTEM option in this fashion, press the letter $S$. The second way is to use the cursor-movement keys to position the pointer over the desired opton and press 〈RETIJRN>. To use this method of selecting SYSTEM, use the right-arrow key until SYSTEM is highlighted by the pointer, then press 〈RETURN>. By using the second method, the description of each option is displayed onscreen as the pointer is moved over its name. The Input Menu options are described below.

Input Menu Option NAME

This option enters your name and organization, information which will later be used as a heading for SYSPLAN's output reports. It is chosen from the Input Menu either by pressing the letter $N$ or by highlighting NAME with the pointer and pressing 〈RETURN>.

When option NAME is chosen, the screen shown in Figure 2.12 is displayed. In addition, a message is written to the the top of the screen, reading:

\section{PRESS RETURN TO BEGIN...ESCAPE (ESC) WHEN FINISHED}

When you press <RETURN> as prompted, SYSPLAN moves the pointer to the first item to be entered--for this option, to the cell containing "Analyst's Name." You can change the cell's contents by typing your name and pressing 〈RETURN>. After 〈RETURN> is pressed, the new contents will be displayed in the cell. 


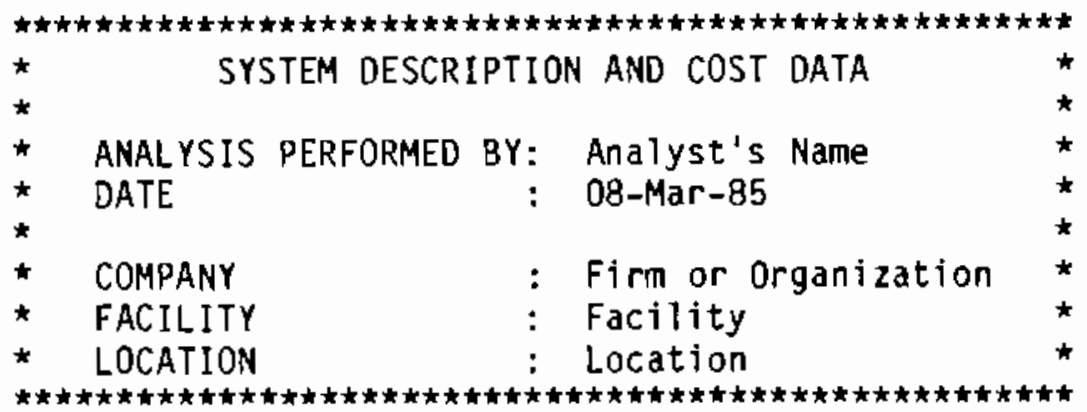

FIGURE 2.12. Input Menu Option NAME Screen

While the infomation under option NAME is being entered, the cursormovement keys allow you to position the pointer only over those items which are to be changed. For option NAME, these items are:

- Analyst's Name

- Company

- Facility

- Location.

The current date is displayed onscreen but cannot be changed (it is generated automatically by SYSPLAN).

You can continue to make changes to the four items listed above until you are satisfied with their contents. When you are finished, press 〈ESC〉. This moves the pointer back to the Input Menu, allowing you to select another option.

\section{Input Menu Option RETRIEVE}

This option can be used to read the information generated by the XSIZE sizing spreadsheet into the SYSPLAN spreadsheet. The sizing worksheet generates utility charge and battery operating information. The RETRIEVE option can be selected from the Input Menu either by pressing the letter $\mathrm{R}$ or by highlighting RETRIEVE with the pointer and pressing <RETURN>.

When the RETRIEVE option is chosen, the spreadsheet looks for the file SIZE.WKS on the disk. (SIZE.WKS is the most recent output file created from the sizing spreadsheet.) If it finds this file, it will read the information 
from it into sYSPLAN. In this way, utility charge and battery operating information for a battery system are input automatically. If the SIZE.WKS fiTe is not found, an error message will be displayed. Clear the error message by pressing $\langle E S C\rangle$, then find the file on disk if you want to select RETRIEVE. again.

When this file transfer is completed, the pointer returns to the Input Menu, allowing you to select another option. If you use the RETRIEVE option to input utility charge and operating data, you should al so select UCHARGE to enter a utility name, and OPERATING to enter peak shaved in cycles data (terms are defined in Chapter 3.0). You can also use UCHARGE and OPERATING to modify the information retrieved from the sizing worksheet.

Input Menu Option UCHARGE

This option is chosen to enter the name of the utflity being analyzed and information on its utility charge structure. It is chosen from the Input Menu either by pressing the letter $U$ or by highlighting JCHARGE with the pointer and pressing 〈RETURN〉.

When option UCHARGE is chosen, the screen shown in Figure 2.13 is displayed. In addition, a message is written to the the top of the screen, reading:

PRESS RETURN TO BEGIN...ESCAPE (ESC) WHEN FINISHED

When you press <RETURN> as prompted, SYSPLAN moves the pointer to the name of the utility being analyzed - the first item to be changed for this option. You can change the cell's contents by typing the utility's name and pressing 〈RETURN>. After 〈RETURN> is pressed, the new contents will be displayed in the cell.

While the information uader option UCHARGE is being entered, the cursormovement keys allow you to position the pointer only over those items which are to be changed. Option UCHARGE allows up to forty-nine items to be changed, as listed below:

- Name of Utility Being Analyzed

- Off-Peak Energy Charge for each month 


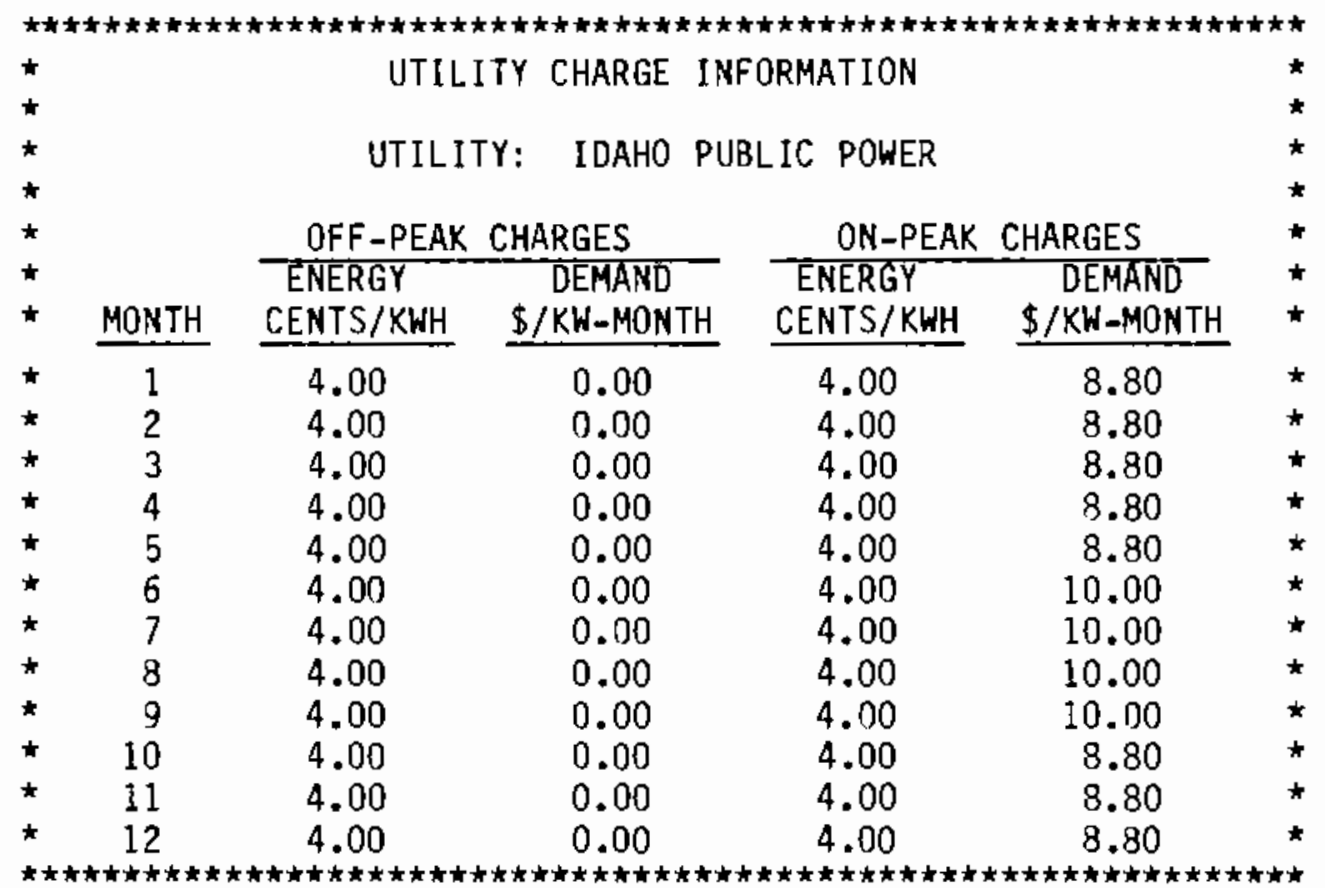

FIGURE 2.13. Input Menu Option UCHARGE Screen

- Off-Peak Demand Charge for each month

- On-Peak Energy Charge for each month

- On-Peak Demand Charge for each month.

You can continue to make changes to these items until you are satisfied with their contents. When you are finished, press 〈ESC〉. This moves the pointer back to the Input Menu, allowing you to select another option.

Input Menu Option OPERATING

This option is chosen to enter operating information for the proposed battery system. It is chosen fram the Input Menu either by pressing the letter 0 or by highlighting OPERATING with the pointer and pressing 〈RETURN>.

When option OPERATING is chosen, the screen shown in Figure 2.14 is displayed. In addition, a message is written to the the top of the screen, reading:

PRESS RETURN TO BEGIN...ESCAPE (ESC) WHEN FINISHED 


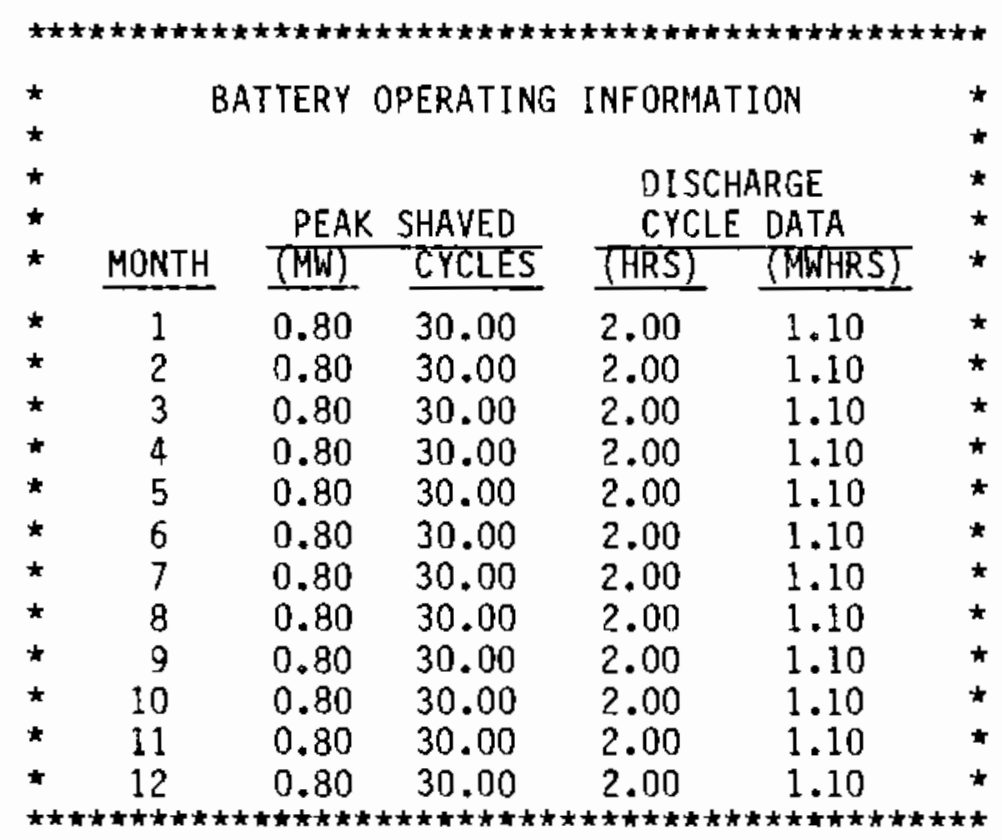

FIGURE 2.14. Input Menu Option OPERATING Screen

When you press <RETURN> as prompted, SYSPLAN moves the pointer to the Peak Shaved (MW) amount for Month 1-- the first item to be changed for this option. You can change the cell's contents by typing a different amount and pressing 〈RETURN>. After 〈RETURN> is pressed, the new contents will be displayed in the cell.

While the information under option OPERATING is being entered, the cursormovement keys allow you to position the pointer only over those items which are to be changed. Option OPERATING allows up to forty-eight items to be changed, as listed below:

- Peak Shaved in Megawatts for each month

- Peak Shaved in Cycles for each month

- Discharge Cycle in Hours for each month

- Discharge Cycle in Megawatt Hours for each month.

You can continue to change these items until you are satisfied with their contents. When you are finished, press $\langle E S C\rangle$. This moves the pointer back to the Input Menu, allowing you to select another option. 


\section{Input Menu Option SYSTEM}

This option is chosen in order to enter a description of the proposed battery system. It is chosen from the Input Menu either by pressing the letter $S$ or by hightighting SYSTEM with the pointer and pressing 〈RETURN>.

When option SYSTEM is chosen, the screen shown in Figure 2.15 is displayed. In addition, a message is written to the top of the screen, reading:

\section{PRESS RETURN TO BEGIN...ESCAPE (ESC) WHEN FINISHED}

When you press <RETURN> as prompted, SYSPLAN moves the pointer to the Battery Capacity in Megawatts amount - the first item to be changed for this option. You can change the cell's contents hy typing a different amount and pressing 〈RETURN〉. After 〈RETURN〉 is pressed, the new contents will be displayed in the cell.

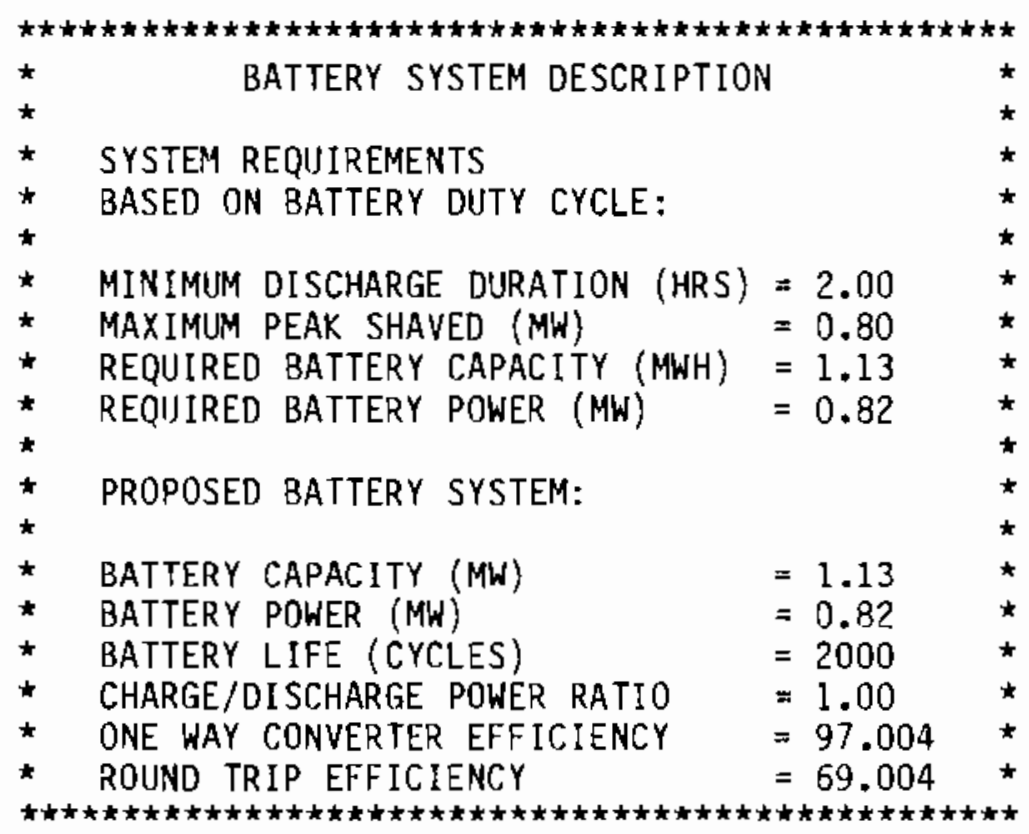

FIGURE 2.15. Input Menu Option SYSTEM Screen 
While the information under option SYSTEM is being entered, the cursormovement keys allow you to position the pointer only over those items which are to be changed. Option SYSTEM allows up to six items to be changed:

- Battery Capacity in Megawatts

- Battery Power in Megawatts

- Battery Life in Cycles

- Charge/Discharge Power Ratio

- One Way Converter Efficiency

- Round Trip Efficiency.

The four items listed below also are displayed on this screen, but cannot be changed because they are calculated automatically by SYSPLAN:

- Minimum Discharge Duration in Hours

- Maximum Peak Shaved in Megawatts

- Required Battery Capacity in Megawatt Hours

- Required Battery Power in Megawatts.

You can continue to make changes to the first six items until you are satisfied with their contents. When you are finished, press $\langle E S C\rangle$. This moves the pointer back to the Input Menu, allowing you to select another option.

Input Menu Option COST

This option is chosen in order to enter cost information for the proposed battery system, cost and utility charge escalation rates and tax rates to be used in the analysis. It is chosen from the Input Menu either by pressing the letter $C$ or by highlighting COST with the pointer and pressing 〈RETURN>.

When option COST is chosen, the screen shown in figure 2.16 is displayed. In addition, a message is written to the top of the screen, reading:

\section{PRESS RETURN TO BEGIN... ESCAPE (ESC) WHEN FINISHED}

When you press <RETURN> as prompted, SYSPLAN moves the pointer to Installed Battery cost - the first item to be changed under this option. You can change 


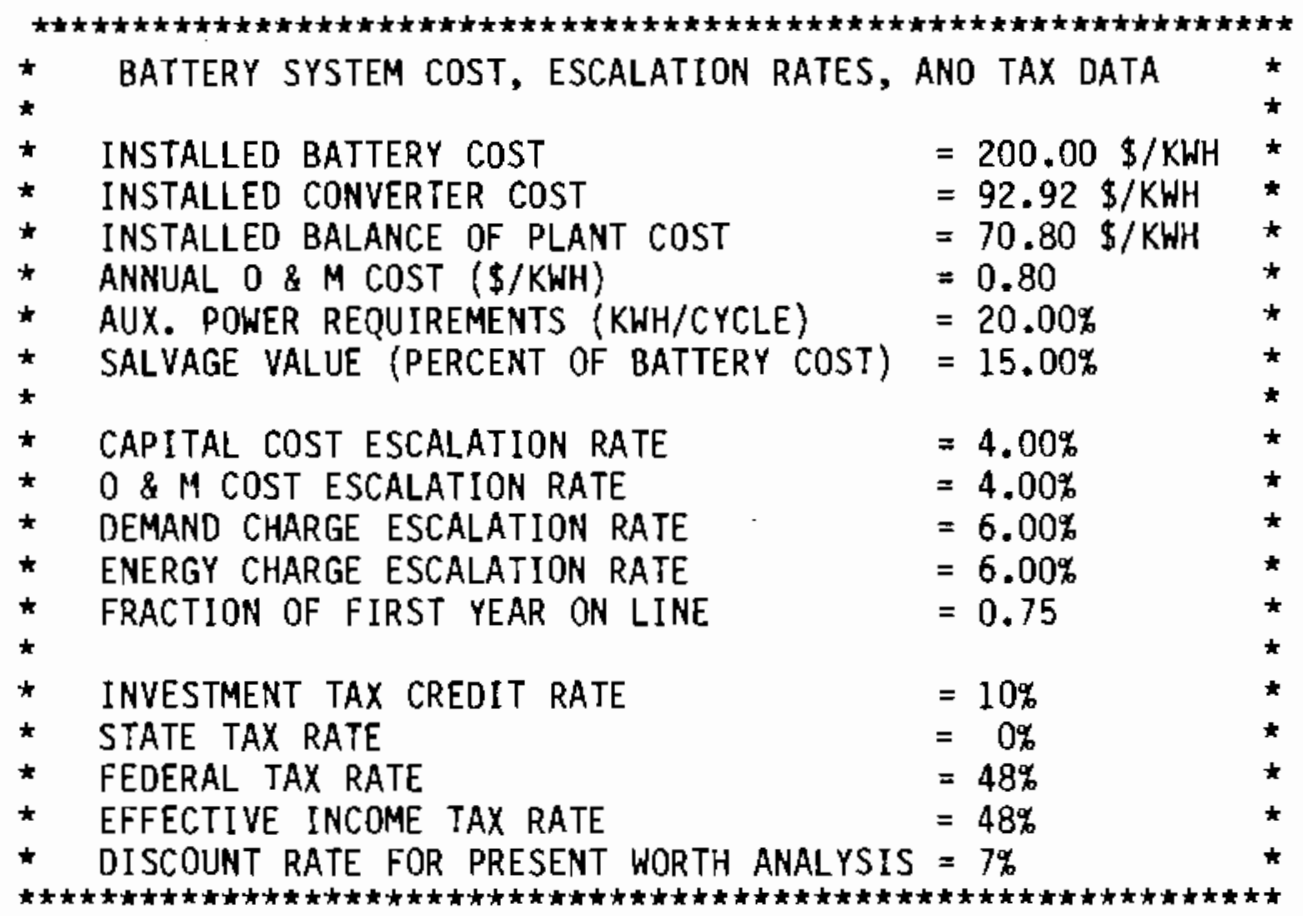

FIGURE 2.16. Input Menu Option COST Screen

the cell's contents by typing a different amount and pressing 〈RETURN〉. After 〈RETURN> is pressed, the new contents will be displayed in the cell.

While the infomation under option COST is being entered, the cursormovement keys allow you to position the pointer only over those items which are to be changed. Option COST allows up to fifteen items to be changed:

- Installed Battery Cost

- Installed Converter Cost

- Installed Balance of Plant Cost

- Annuar 0 \& M Cost

- Auxiliary Power Requirements (Megawatt Hours per Cycle)

- Salvage value (as percent of Battery Cost)

- Capital Cost Escalation Rate

- 0 \& Cost Escalation Rate

- Demand Charge Escalation Rate

- Energy Charge Escalation Rate

- Fraction of First Year On Line 
- Investment Tax Credit Rate

- State Tax Rate

- Federal Tax Rate

- Discount Rate for Present Worth Analysis.

The Effective Income Tax Rate is also displayed on this screen, but because it is calculated from the other tax rates it cannot be changed by the user.

You can continue to change these items until you are satisfied with their contents. When you are finished, press $\langle E S C\rangle$. This moves the pointer back to the Input Menu, allowing you to select another option.

Input Menu Option QUIT

Option QUIT is chosen after all infomation describing the battery system has been entered under the other Input Menu options. It can be selected from the Input Menu either by pressing the letter $Q$ or by highlighting QUIT with the pointer and pressing 〈RETURN>.

When option QUIT is chosen, the Input Menu is erased from the top of the screen, and the screen displays the Main Menu shown in Figure 2.11. You are now ready to run the case just entered.

ALT-A - Running a SYSPLAN Case

F9 (CALC key) - Run the case most recently input.

The F9 key (Lotus 123 CALC key) runs a SYSPLAN case using the values most recently entered from the Input Menu (ALT A). F9 must be pressed to incorporate newly entered values into other SYSPLAN calculations. The F9 key updates the items wich were displayed but not entered from the Input Menu screens. It also updates SYSPLAN's Economic Analysis Summary and provides current values for graphs and output reports.

To run a SYSPLAN case, merely press the F9 (CALC) key and wait approximately ten seconds for updated results to be displayed. F9 can be used from anywhere within the worksheet except from within the Input and Ana?ysis Menus. (If one of these menus is displayed at the top of the screen, choose the QUIT option to return to the Main Menu, then press F9.) 
After the latest case is calculated with $F 9$, other macros can be used to display and print results; results can be expanded by performing sensitivity analyses. These capabilities are described below.

ALT B - View Economic Analysis Summary

The ALT B macro program allows users to view SYSPLAN'S Economic Analysis Summary onscreen. The Economic Analysis Sumnary provides an income statement, including Net and Cumulative Cash Flow amounts and Return on Investment, for each of the twenty years for which the proposed battery system is analyzed. It is created whenever the F9 (CALC) key is pressed.

To view the Economic Analysis Summary, press the ALT key and the letter B simultaneously. When ALT and B are pressed, the top left corner of the sumnary is displayed. This macro can be used from anywhere within the worksheet except from within the Input and Analysis Menus. (If one of these menus is displayed at the top of the screen, choose the QUIT option to return to the Main Menu, then press ALT and B.)

The Economic Analysis Summary is over two screens wide and over two screens long. To view different areas in the summary, the cursor-movement keys can be used. A quicker way to move around in the summary is to use the 〈PGUP> and $\langle P G D N\rangle$ keys to move up and down within the summary, 〈TAB> and SHIFTto move left and right. (Experienced Lotus 123 users may wish to use the Worksheet Window command to set a vertical window at Column $M$ of the SYSPLAN spreadsheet.)

When you are finished looking at the Economic Analysis Sumnary, you may wish to obtain a printed version with the ALT $F$ macro, press <HOME> to return to the Main Menu, or invoke another macro.

ALT C - View Net Cash Flow Graph/ALT D - View Cumulative Cash Flow Graph

These two macro programs format the most recently calculated results into graphs and display them on the screen. The ALT C macro displays a graph of the net cash flow over the twenty years included in the analysis of the proposed battery system. Figure 2.17 shows an example of the net cash flow graph. The ALT D macro displays a graph of the cumulative cash flow in dollars for each of the twenty years. A sample cumulative cash flow graph is shown in Figure 2.18. 


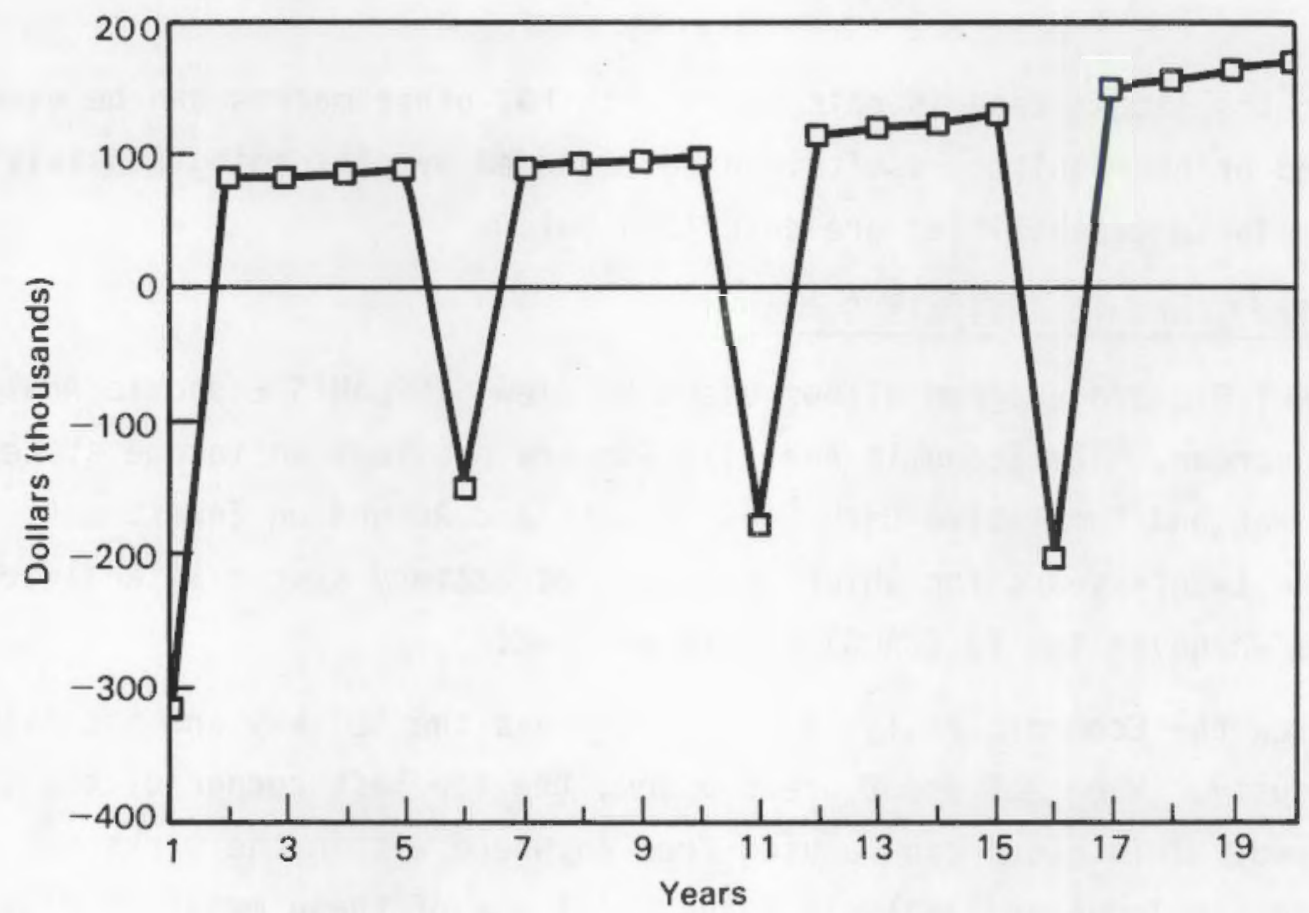

FIGURE 2.17. Net Cash Flow Graph

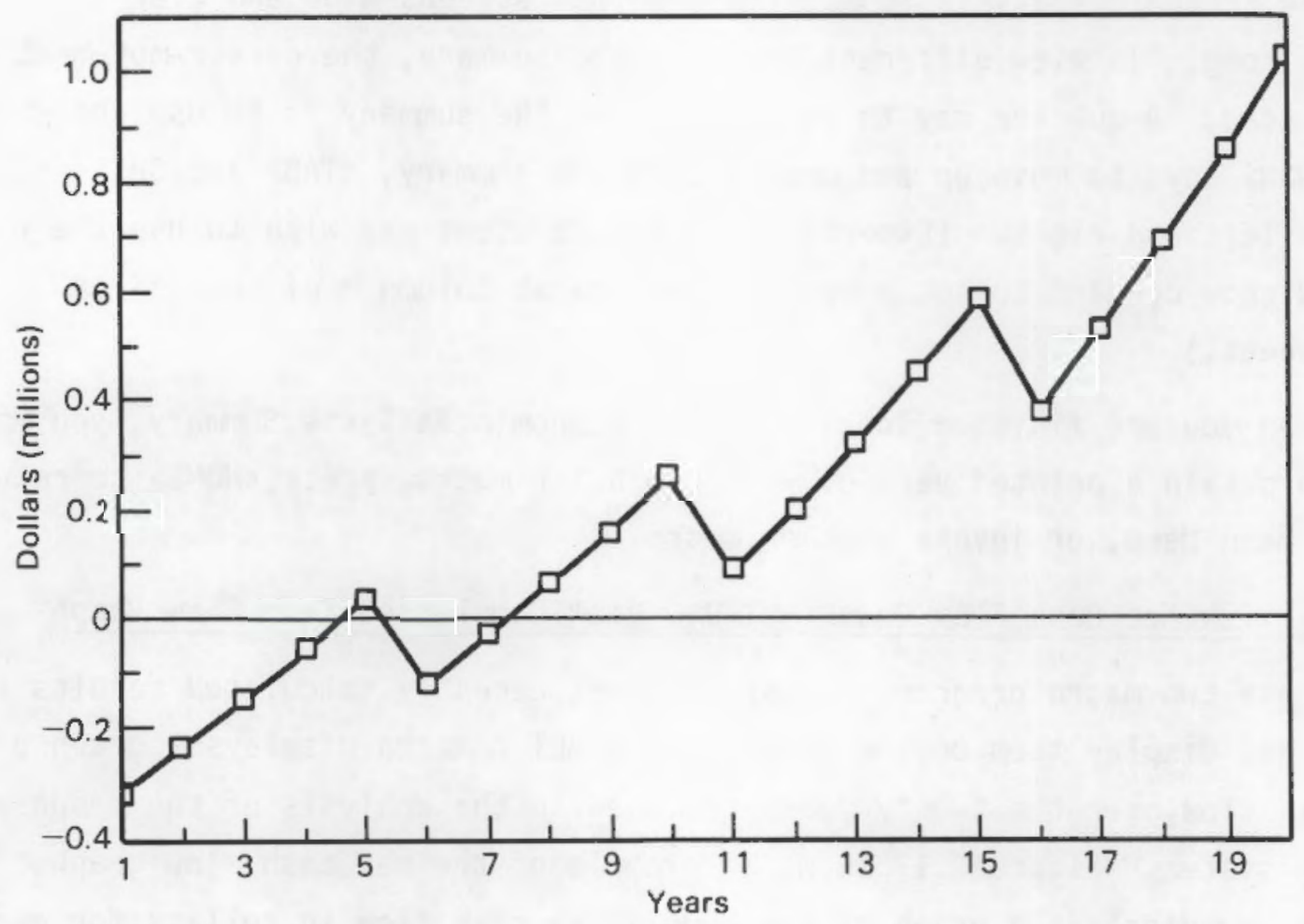

FIGURE 2.18. Cash Flow Graph 
Each of these macros can be invoked from anywhere in the SYSPLAN spreadsheet except from within the Input and Analysis Menus. (If one of these inenus is displayed at the top of the screen, choose the QUIT option to return to the Main Menu before attempting to display a graph.) To look at the Net Cash Flow graph, press the ALT key and the letter C simultaneously. To view the cumulative cash flow graph, press ALT and D simultaneously.

When one of these key combinations is pressed, the graph associated with it will be displayed on the screen, temporarily erasing the spreadsheet from the screen. After looking at the graph, press any key to bring the spreadsheet back onscreen. If you want to save either graph onto the disk for later printing, the next section provides details on the Lotusl23/gs (Graph Save) command which makes spreadsheet graphs available to the Lotus PrintGraph progran for printing.

/gs (Graph Save) - Save a graph to file for printing

The Lotus $123 /$ gs (Graph Save) command saves the most recently displayed graph onto the disk as a graph file. This gives the Lotus PrintGraph program access to the graph so that it can be printed after the SYSPLAN session has been concluded.

To save a graph to file, type in the command below, replacing FILENAME with the name you wish to give the graph file (this name can contain up to eight letters, but should not be given a file extension). The graph should not be displayed on the screen when you begin typing in the command.

/gSFILENAME 〈RETURN〉

If a file FILENAME.PIC al ready is stored on disk, you will be asked whether you want to replace the file or to cancel the command. Press either $C$ to cancel the /gs command or $R$ to overwrite the old file. 
The /gs command only saves the most recently seen graph to file. Thus, to save copies of both cash flow graphs requires four steps:

1. Press ALT and $C$ for the net cash flow graph.

2. Use the /gs command to save the net cash flow graph.

3. Press ALT and D for the cumulative cash flow graph.

4. Use the /gs command to save the cash flow graph.

For more details on the Graph Save command, and for instructions for using the Lotus PrintGraph program, refer to your Lotus123 manual.

ALT E - Print System Description and Cost Data / ALT F - Print Economic

Analysis Summary

These two macro prograns format output reports and send them to your printer. The ALT E macro prints a two-page report showing the inputs to the proposed battery system (the items entered under the various options of the Input Menu). The first page of this report is shown in Figure 2.19. The ALT D macro prints a three-page report containing the information shown in SYSPLAN's Economic Analysis Sumnary (in thousands of dollars) for each of the twenty years analyzed. A sample of the first page of this report is shown in Figure 2.20. A third report, on the results of a sensitivity analysis, is printed from within the Analysis Menu.

Each of these macros can be invoked from anywhere in the SYSPLAN spreadsheet except from within the Input and Analysis Menus. (If one of these menus is displayed at the top of the screen, choose the QUIT option to return to the Main Menu before printing a report.) Before printing a report, be sure that your printer is turned on and aligned to the top of the page, and that you have recently pressed $F 9$ (CALC) to update the spreadsheet. To print a report of the battery system description, press the ALT key and the letter E simultaneously. To print the Economic Analysis Summary, press ALT and D simultaneousiy.

When either of the report-printing macros is initiated, the screen display changes rapidly for a few seconds as the computer finds the information for the report. The report will begin to print. As soon as the 'READY' prompt is 


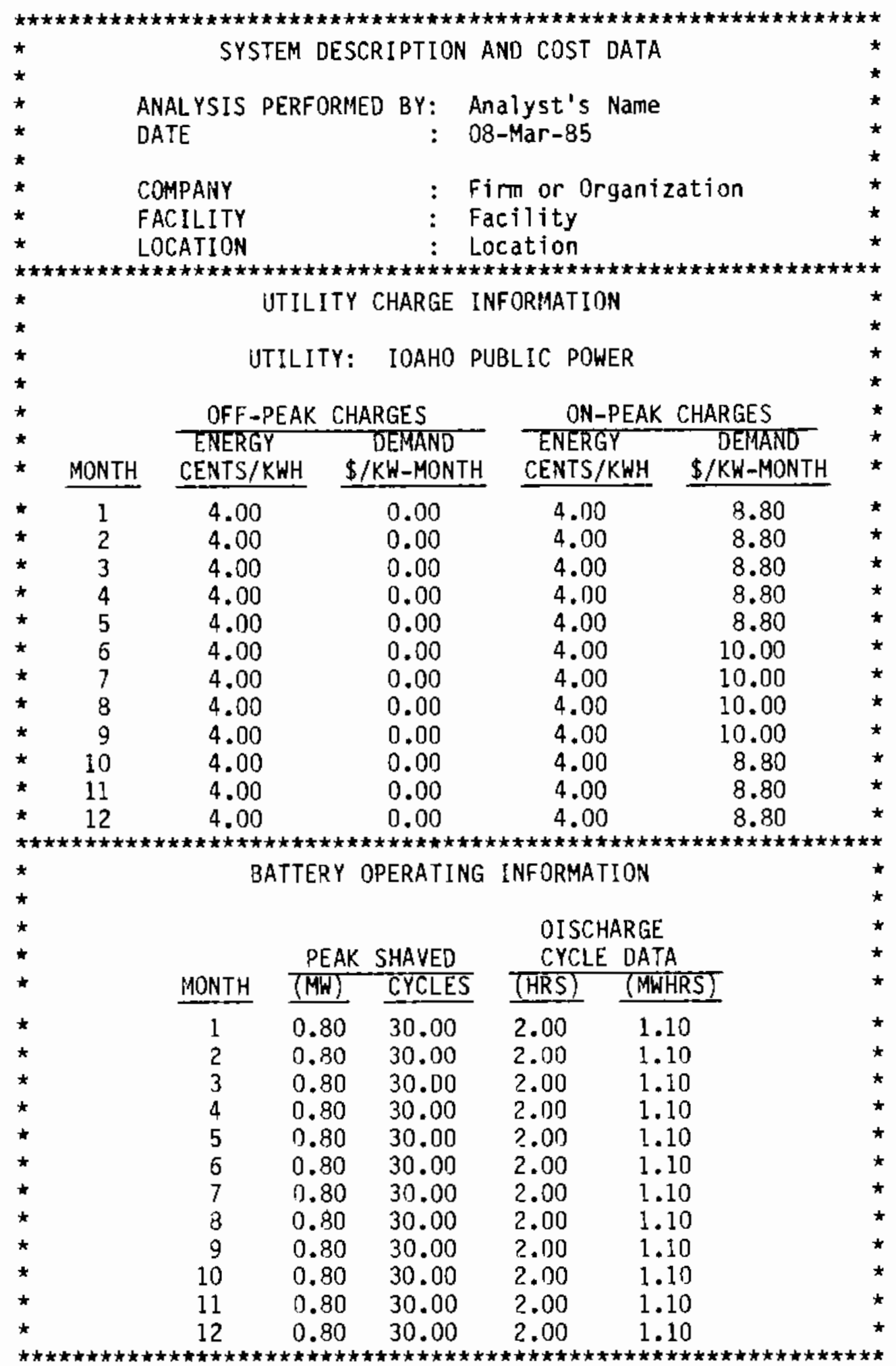

FIGURE 2.19. Battery System Description Report 


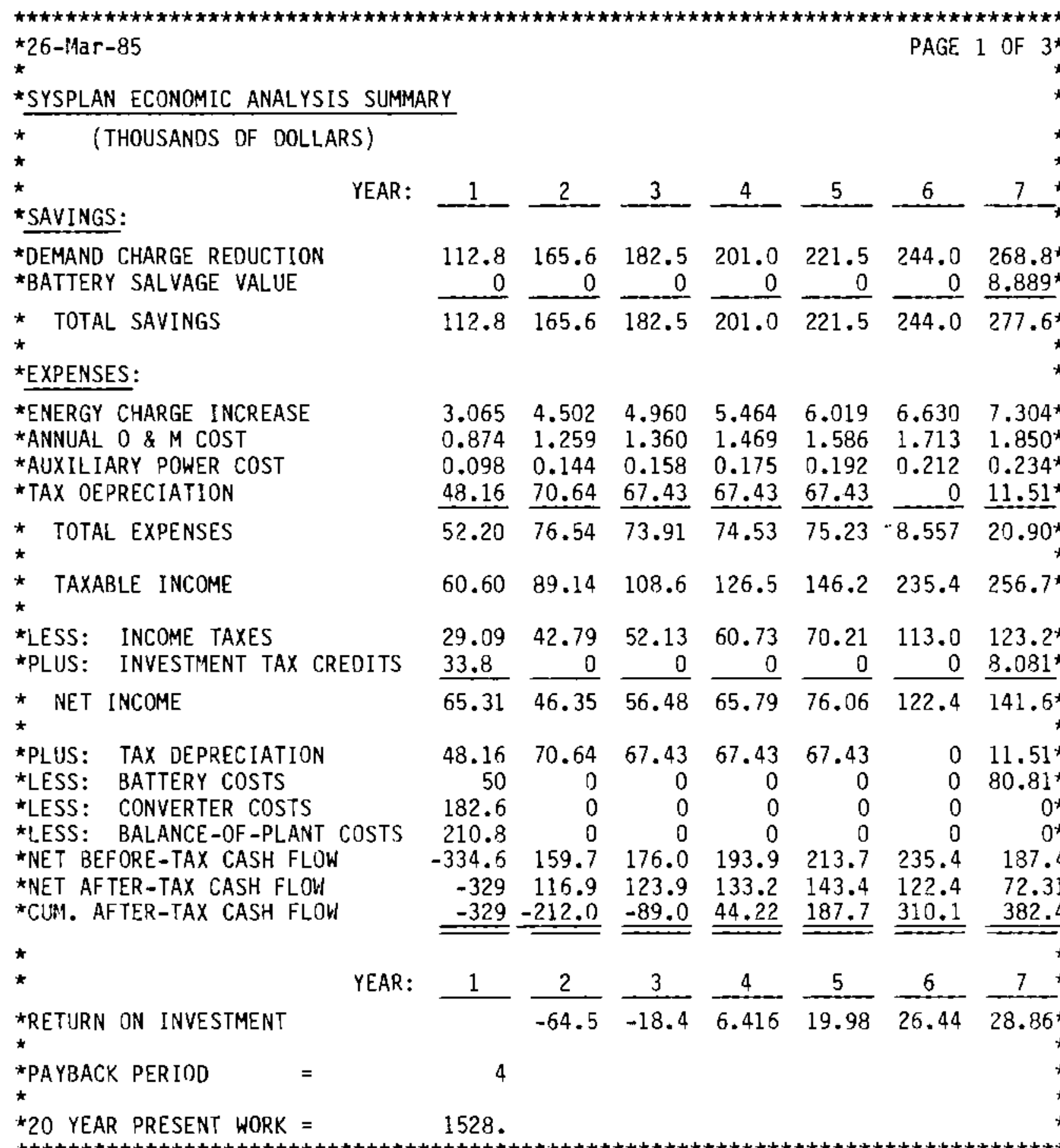

FIGURE 2.20. Economic Analysis Summary Report 
displayed at the top of the screen, you can press 〈MOME> to return to the Main Menu, run another macro or type a Lotus 123 command, even if the report is still printing.

ALT G - Set up and Run Sensitivity Analyses

The ALT G macro is used to prepare for and to run sensitivity analyses for proposed battery systems. In these analyses, a range of values for a selected independent variable is specified, and the resulting values of dependent variables are calculated. All other input variables are held constant during the calculations. In the SYSPLAN spreadsheet, users choose between five independent variables, and specify the minimum and maximum values that the variables will take. After calculating three intermediate values for the independent variable, SYSPLAN gives resulting values of both the payback period for the battery system and the discounted present worth of the system.

Before running sensitivity analyses, make sure that the system description is correct by printing the description ( $A L T E$ ) or using the Input Menu (ALT A). Then, to begin, press the ALT key and the letter G simultaneously. The screen shown in Figure 2.21 will appear, with a menu above it. This Analysis Menu offers the six options listed below. The descriptions can also be seen by moving the pointer among the menu options shown onscreen.

\begin{tabular}{|c|c|}
\hline Option & Description \\
\hline SETUP & SET UP AN INDEPENDENT VARIABLE (FIVE CHOICES) \\
\hline RUN & $\begin{array}{l}\text { RUN THE ANALYSIS WITH THE VARIARLE AND VALUES } \\
\text { DISPLAYED DN SCREEN }\end{array}$ \\
\hline WORTH & $\begin{array}{l}\text { GRAPH PRESENT WORTH AGAINST INDEPENDENT VARIABLE } \\
\text { SHOWN }\end{array}$ \\
\hline GPAYAACK & $\begin{array}{l}\text { GRAPH PAYBACK PERIOD AGAINST INDEPENDENT VARIABLE } \\
\text { SHOWN }\end{array}$ \\
\hline PRINT & PRINT THE ANALYSIS RESULTS \\
\hline QUIT & RETURN TO THE MAIN MENU \\
\hline
\end{tabular}




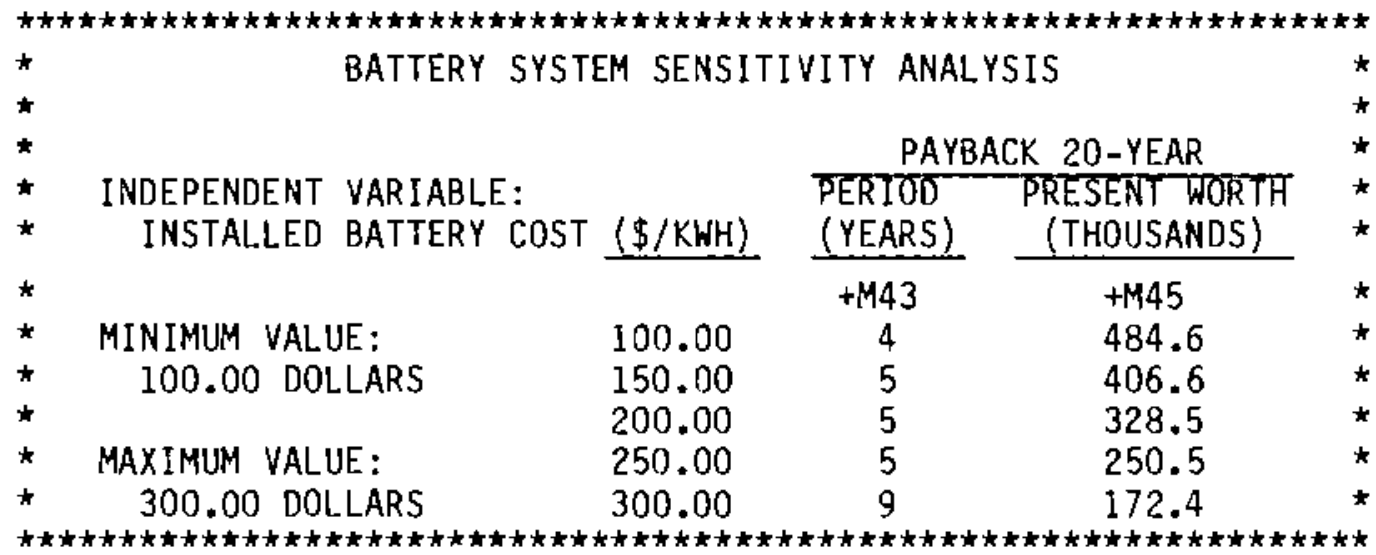

\section{FIGURE 2.21. Sensitivity Analysis Screen}

An option can be selected in either of two ways. One way is to type the first letter of the option. For example, to choose the RUN option in this fashion, press the letter $R$. The second way is to use the cursor-movement keys to position the pointer over the desired option and press <RETURN>. To use this method of selecting RUN, use the right-arrow key until RUN is highlighted by the pointer, then press <RETURN>.

The SETUP option is used to set up an independent variable. Independent variables available for sensitivity analysis are:

- battery cost

- demand charge escalation

- battery life

- federal tax rate

- converter roundtrip efficiency.

After an independent variable has been installed, the RUN option is used to calculate the values of the two dependent variables. Results can then be printed with the PRINT option. These three steps (set up, RUN and PRINT) can be repeated as many times as needed. When no more sensitivity analyses are needed, choose the QUIT option to erase the Analysis Menu from the top of the screen and return to the Main Menu. 
The Analysis Menu options are described below.

Analys is Menu Option SETUP

This Analysis Menu option is used to select and set up an independent variable for a sensitivity analysis. Only one independent variable can be used at a time. The SETUP option displays five independent variables that can be selected for the sensitivity analysis. Each can be selected by pressing the first letter of the option or by highlighting the option with the pointer and pressing <RETURN>. These options are described below:

COST - Sets up installed battery cost $(\$ / K W H)$ as the independent variable

ESCALATION - Sets up demand charge escalation rate as the independent variable

LIFE - Sets up battery life in cycles as the independent variable

TAXRATE - Sets up federal tax as the independent variable

RNDTRIP - Sets up roundtrip converter efficiency as the independent variable

When any one of these options is chosen, the steps listed below are followed:

1. The name of the independent variable chosen is written onto the screen, as well as the units in which the minimum and maximum values for that variable should be entered. Also, the cells containing numeric values are reformatted if necessary.

2. A prompt is written at the top of the screen. It reads: PRESS RETURN TO ENTER MIN, MAX VALUES, ESCAPE (ESC) WHEN FINISHED Press 〈RETURN>. The pointer is moved to the cell for the minimum value. Enter the minimum value for the independent variable and press <RETURN>. Use any cursor-movement key to move to the cell for 
the maximum value. Type in the maximum value and press <RETURN>. Either value can be changed again if necessary. When you are satisfied with both values, press $\langle E S C\rangle$.

3. SYSPLAN copies the minimum and maximum values to the far left column of the analysis table and computes three intermediate values for the independent variable. When this operation is completed, a message is displayed at the top of the screen:

ALL DONE! ...PRESS RETURN, THEN CHOOSE THE 'RUN' OPTION

Press <RETURN>. The Analysis Menu is displayed again at the top of the screen.

If you are satisfied with the independent variabie and the values (minimum, maximum and intermediate) displayed on the screen, your next step is to choose the RUN option which calculates values for the dependent variables. However, you may set up the same or a different independent variable as many times as you wish before calculating results with the RUN option.

Analysis Menu Option RUN

This option is used to calculate the values of dependent variables, given the independent variable and values specified in option SETUP. For each value of the independent variable, the payback period and discounted present worth of the battery system are calculated. The RUN option is selected either by pressing the letter $R$ or by highlighting RUN with the pointer and pressing <RETURN>.

When this option is chosen, the message below is written at the top of the screen.

\section{THIS WILL TAKE 2-3 MINUTES...PRESS RETURN TO BEgIN}

Press <RETURN>. While the calculations are being made, the 'WAIT' prompt fiashes at the top of the screen. When they are finished, the READY prompt is displayed, the updated values of the dependent variables are displayed on the 
screen, and the Analysis Menu reappears above it. If you want a printed record of the results, choose the PRINT option next.

\section{Analysis Menu Option PRINT}

This option formats a one-page output report of the most recent sensitivity analysis and sends it to your printer. A sample report is shown in Figure 2.22.

Before printing a report, be sure that your printer is turned on and aligned to the top of the page, and that you have updated the dependent variables with the RUN option. To select the PRINT option, either press the letter $P$ or highlight PRINT with the pointer and press <RETURN>.

The report will begin to print. When the READY prompt and the Analysis Menu are displayed at the top of the screen, you can set up another sensitivity analysis with SETUP, or return to the Main Menu with the QUIT option.

\begin{tabular}{|c|c|c|c|c|c|}
\hline * & \multicolumn{4}{|c|}{ SYSTEM DESCRIPTION ANO COST DATA } & \\
\hline r & \multicolumn{4}{|c|}{ ANALYSIS PERFORMED BY: Analyst's Name } & \\
\hline 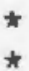 & \multicolumn{4}{|c|}{ DATE $\quad$ : 26-Mar-85 } & \\
\hline * & \multicolumn{4}{|c|}{ : Firm or Orqanization } & \\
\hline 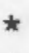 & \multicolumn{4}{|c|}{ : Facility } & 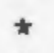 \\
\hline & \multicolumn{4}{|c|}{ : Location } & $x^{2}$ \\
\hline & 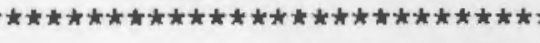 & 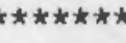 & 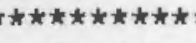 & 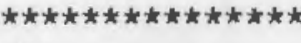 & \\
\hline $\mathbf{r}$ & \multicolumn{4}{|c|}{ BATTERY SYSTEM SENSITIVITY ANALYSIS } & * \\
\hline * & \multicolumn{4}{|c|}{ PAYBACK 20 -YEAR } & \\
\hline k & $\begin{array}{l}\text { INDEPENDENT VARIABLE: } \\
\text { DEMAND CHARGE ESCALATION }\end{array}$ & RATE & $\begin{array}{l}\text { PERIOO } \\
\text { (YEARS) }\end{array}$ & $\begin{array}{l}\text { PRESENT WORTH } \\
\text { (THOUSANDS) }\end{array}$ & \\
\hline * & & & $+M 43$ & $+M 45$ & \\
\hline * & MINIMUM VALUE: & 8.00 & 10 & 100.8 & \\
\hline \# & 8.00 PERCENT & 9.00 & 10 & 195.9 & \\
\hline * & & 10.00 & 9 & 303.2 & \\
\hline * & MAXIMUM VALUE: & 11.00 & 9 & 424.2 & \\
\hline * & 12.00 PERCENT & 12.00 & 6 & 560.9 & $\downarrow$ \\
\hline
\end{tabular}

FIGURE 2.22. Sensitivity Analysis Report 


\section{Analysis Menu Option WORTH}

The Analysis Menu option WORTH graphs the present worth against the independent variable shown by the sensitivity analysis. An example graph showing present worth versus expected battery life is shown in Figure 2.23.

Analysis Menu Option GPAYBACK

The Analysis Menu option GPAYBACK graphs the payback period against the independent variable shown by the sensitivity analysis. An example showing payback period versus expected battery life is shown in Figure 2.24.

\section{Analysis Menu Option QUIT}

Choose option QUIT after all sensitivity analyses for the battery system have been run. It can be selected from the Analysis Menu either by pressing the letter $Q$ or by highlighting QUIT with the pointer and pressing <RETURN>.

When option QUIT is chosen, the Analysis Menu is erased from the top of the screen, and the screen displays the Main Menu shown in Figure 2.11, allowing you to run another macro or type a Lotus123 command.

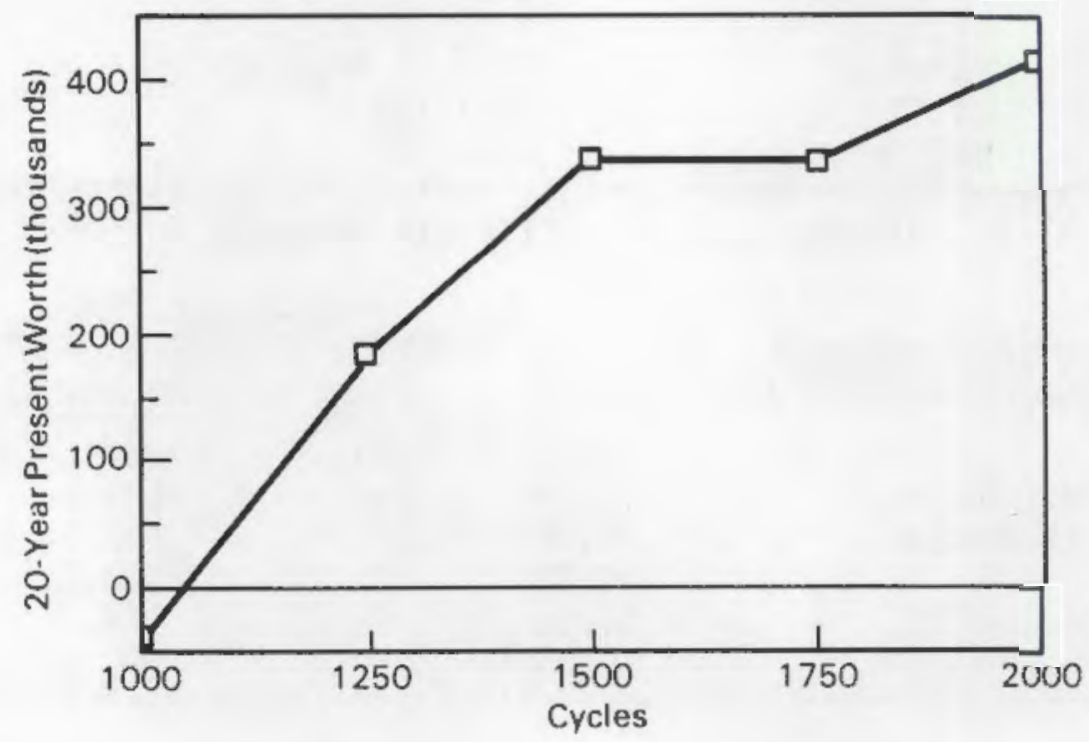

FIGURE 2.23. Example Menu Option WORTH Graph of Present Worth Versus Expected Battery Life 


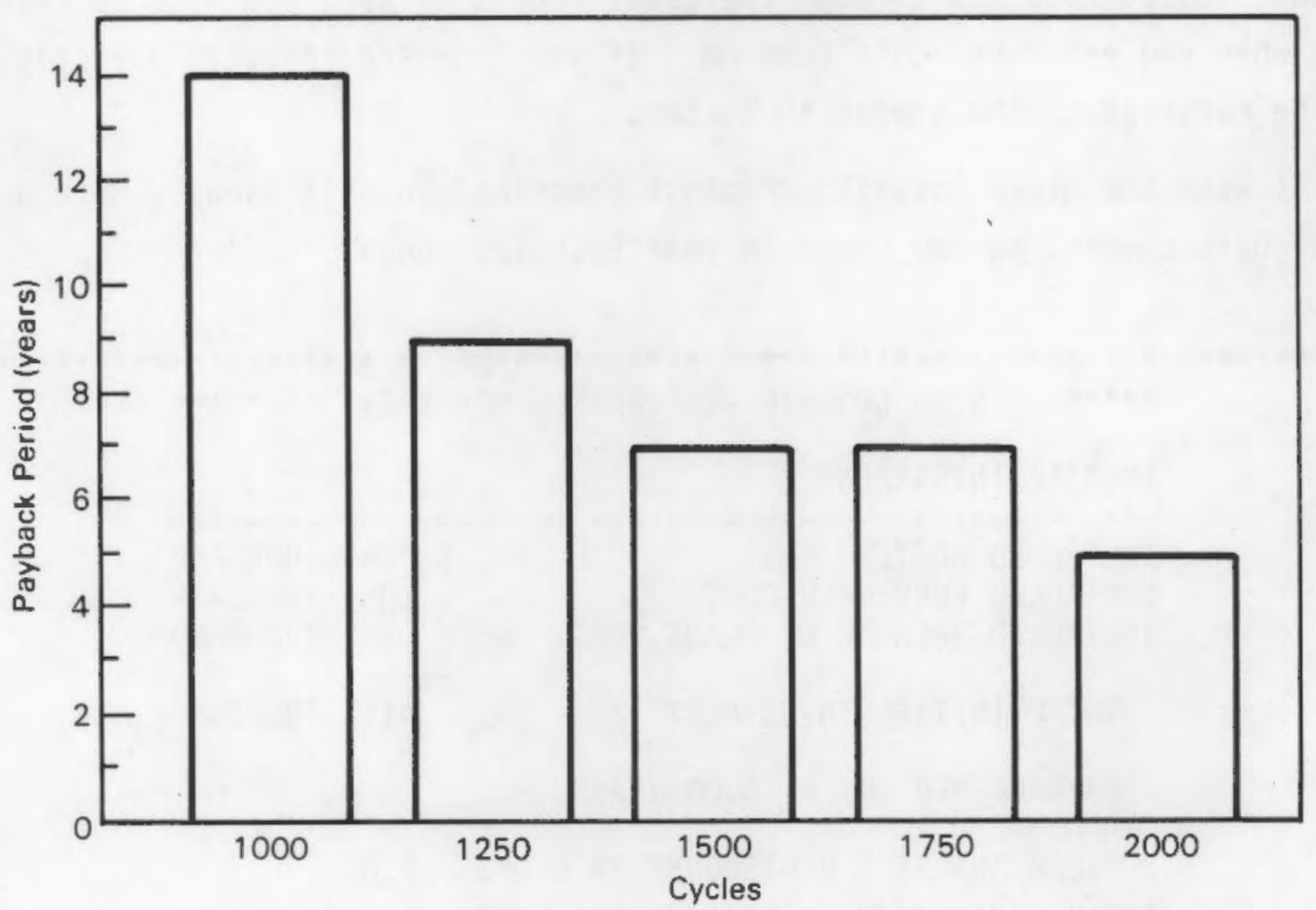

FIGURE 2.24. Example Menu Option GPAYBACK Graph of Payback Period Versus Expected Battery Life

/q (Quit) - Leave Lotus 123

\section{ALT H - View Key Economic Performance Measures}

The ALT H macro displays a summary of key economic results. An example summary of key economic performance measures is shown in Figure 2.25.

This Lotus 123 command is used to leave Lotus123. It should be used when you are finished with your SYSPLAN session. The SYSPLAN spreadsheet does not need to be saved when you quit.

To leave the SYSPLAN model and Lotus 123 , use the Quit command: 
If you accessed Lotus 123 through the Lotus Access System, you will be returned there when you enter the Quit command. If you accessed Lotus 123 directly, you will be returned to the operating system.

As with the other Lotus 123 commands described in this manual, more detail on the Quit command can be found in your Lotus123 manual.

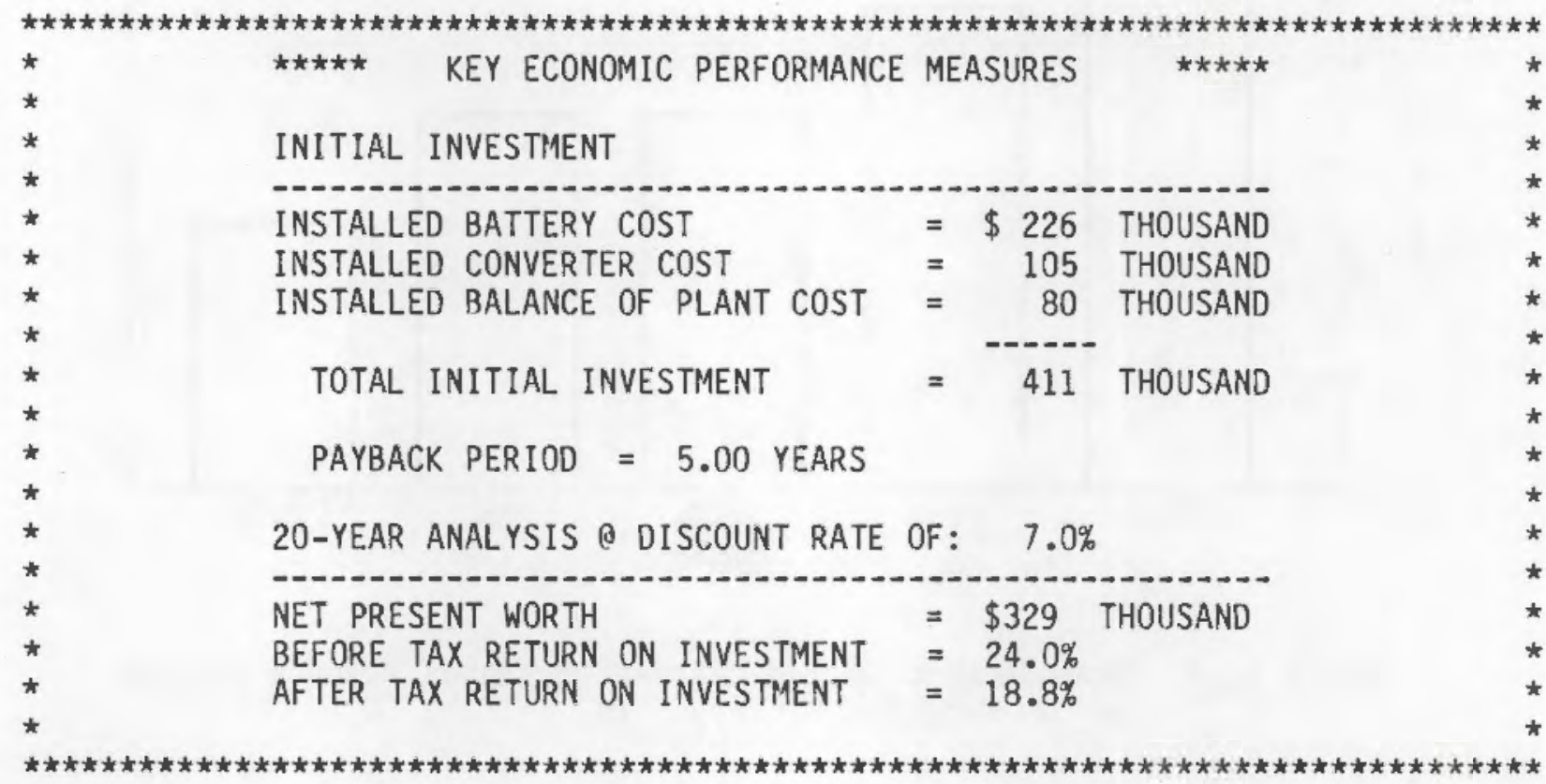

FIGURE 2.25. Example Summary of Key Economic Performance Measures 


\subsection{DESCRIPTION OF INPUT AND OUTPUT TERMS}

Each term included in the costing model and sizing routine is presented in the same order as it appears in the model. A short description and definition of each term is provided to assist the user in entering data and understanding the results.

\subsection{XSIZE SIZING MODEL INPUT/OUTPUT TERMS}

Terms used in the sizing model are typically identical to those in the cost model. The terms used are listed in the order in which they appear. Note al1 discussion of "off-peak" and "on-peak" is with respect to the customer's peak (on the load curve) which may not coincide with the utility system peak. Typical naily Peak (kW) Height of peak power demand (relative to the rest of the time) of customer.

\section{Rate Type -}

On-Peak Demand Charge -

Off-Peak Energy Charge -
On-Peak Energy Charge -

Flat rates incorporate constant energy charges throughout the 24 hour day. Time-ofday (TOD) rates have time-varying energy charges which are generally higher during the utility's peak demand period.

Utility monthly demand charge ( $\$ / \mathrm{kW}$-month) corresponding to the time when the customer's off-peak demand load occurs.

The utility's energy charge when the customer's of $f$-peak occurs, in cents/kwh. The utility's energy charge when the customer's peak occurs, in cents/kWh.

RATTERY OPERATING INFORMATION

Discharge nuration -
Time period of battery discharge (hours). 
Discharge Power Leve1 -

Cycles -

Discharge Energy -
Equivalent to the reduction in the customer's peak power demand as a result of the load leveling battery system.

Number of charge-discharge cycles each month necessary to shave customer peak.

The approximate total energy supplied while shaving a particular peak (MWhrs). It is calculated assuming all peaks are triangular in shape.

3.2 COST MODEL INPUT/OUTPIJT TERMS

UTILITY CHARGE INFORMATION:

Off-Peak Energy Charges.

Off-Peak nemand Charges -

On-Peak Energy Charges -

On-Peak Demand Charges -

Cost of off-peak electricity in cents/kWh. The terms 'off-peak' and 'on-peak' refer to the customer's load profile. Therefore, the cost of off-peak electricity corresponds to the utility's energy charge when the customer's off-peak occurs.

It ility monthly demand charge ( $\$ / k$ li-month) corresponding to the time when the customer's off-peak demand lodd occurs.

Cost of electricity in cents/kWh corresponding to the utility's energy charge when the customers peak occurs.

Utility monthly demand charge ( $\$ / \mathrm{kW}-m o n t h)$ corresponding to the time when the customer's peak demand loart occurs. 
BATTERY OPERATING INFORMATION:

Peak Shaved $(M W)$ -

Peak Shaved Cycles -

Discharge Cycle (Hrs) -

Discharge Cycle (MWhrs) -
Amount of reduction in a customer's monthly peak load as a result of the load leveling battery system.

Number of charge-discharge cycles each month necessary to shave customer demand peak. Duration of battery discharge per cycle. Energy supplied by hattery per discharge cycle.

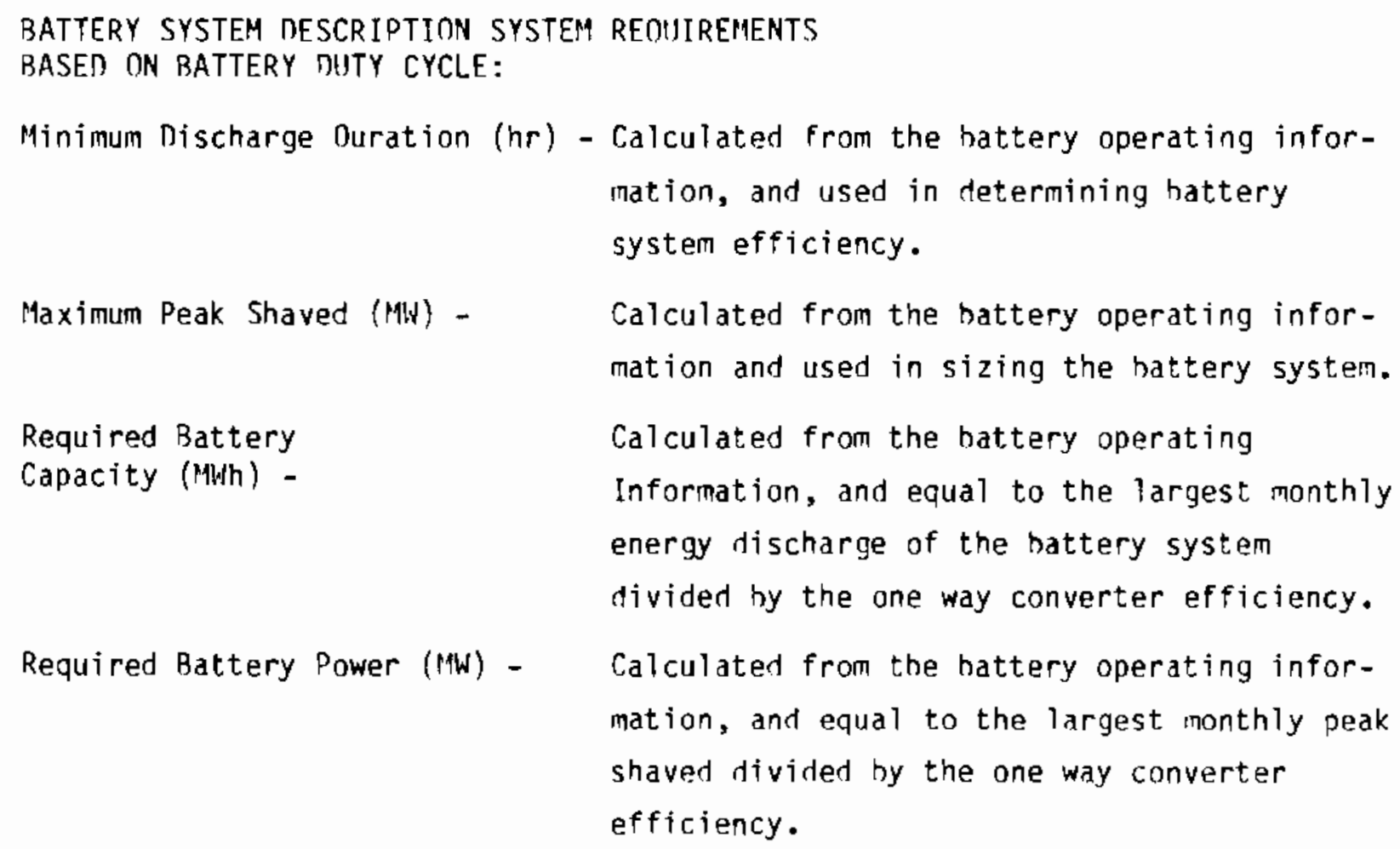

BATTERY SYSTEM DESCRIPTION PROPNSFN

BATTERY SYSTEM:

Battery Capacity (MWh) -

Based on actual proposed system, must he equivalent to or greater than required battery capacity. 


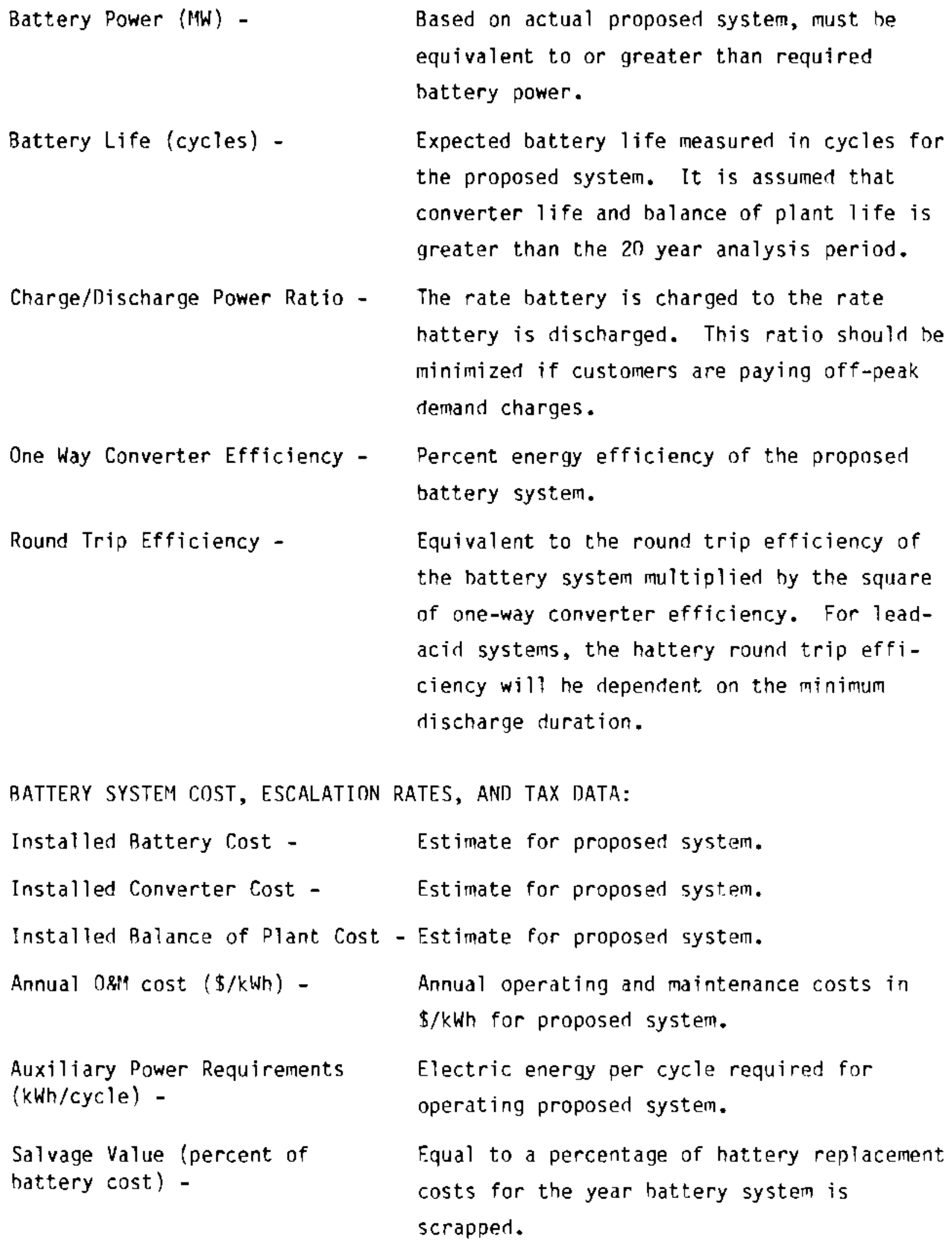




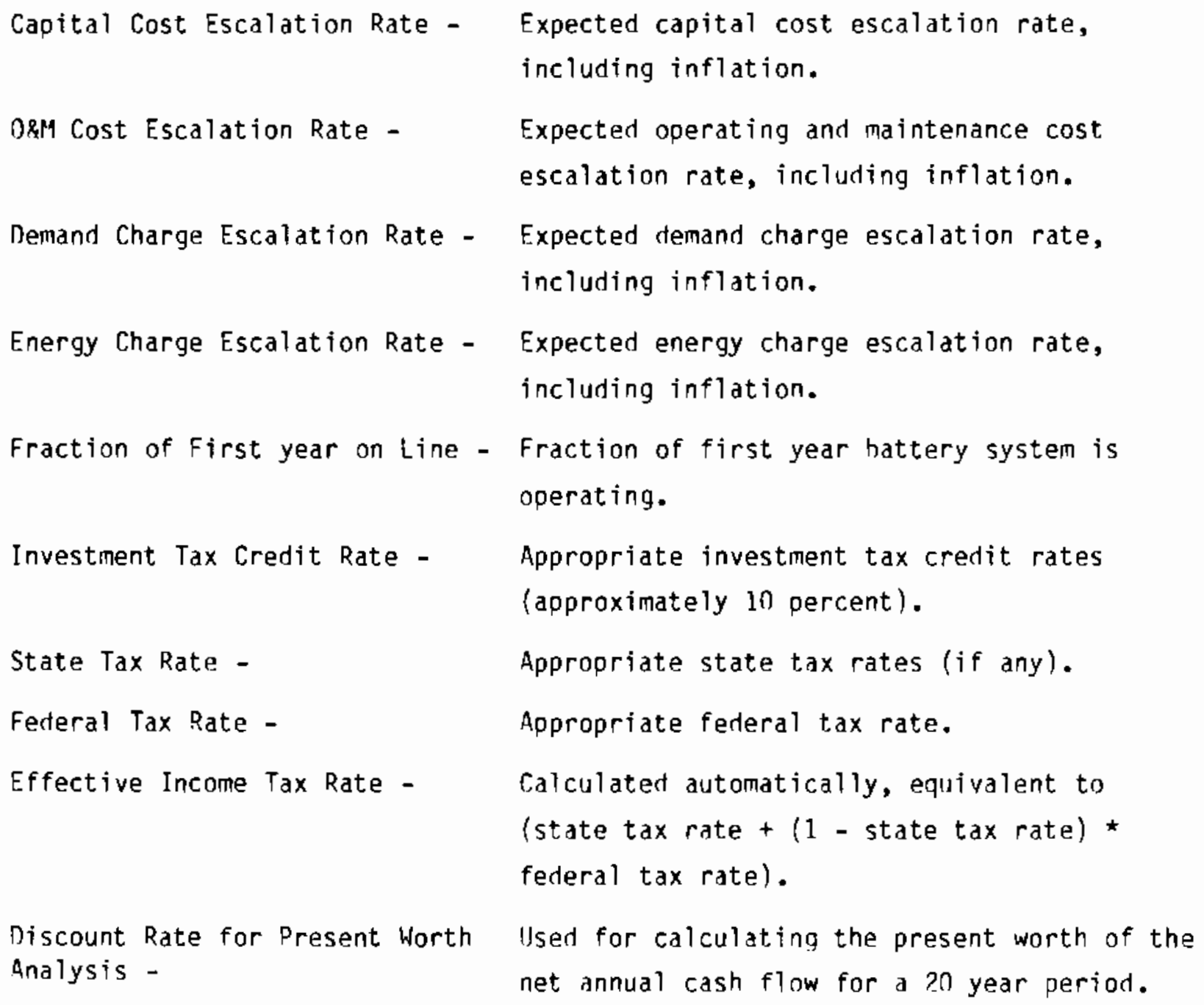

Discount Rate for Present Worth Used for calculating the present worth of the Analysis - net annual cash flow for a 20 year period.

ECONOMIC ANALYSIS SUMMARY SAVINGS:

Demand Charge Reduction - Calculated from monthly peak shaved data and demand charge information using the following expression: Tyearly sum of monthly peaked shaved * on-peak demand charge - (charge discharge ratio * off-peak demand charge) 7 * compounded escalation rate.

Battery Salvage Value - Calculated hy taking the product of battery replacement costs for the year when hattery 
end of life is reached, with the salvage value expressed as a percent.

Total Savings -

\section{EXPENSES:}

Energy Charge Increase -

Annual n\&M Cost -

Auxiliary Power Cost -

Tax Depreciation -
Calculated by summing demand charge reduction with battery salvage value.

Calculated from monthly hattery discharge information, energy charge information, and hattery system efficiency using the following expression: (yearly sum of monthly lWh per discharge * number of cycles per month * 「on-peak energy charge - (off-peak energy charge * round trip efficiency) 7 * compounded escalation factor.

Calculated by taking the product of annual 0\&M cost in $\$ / \mathrm{kWh}$ with the proposed battery capacity, multiplied by the compounded escalation factor.

Calculated by taking the product of the auxiliary power requirement in $\mathrm{kWh} / \mathrm{cycle}$ and the number of cycles per year with the average off-peak energy cost and the compounded energy escalation.

C,alculated hy using the ACRS Rules for 5-year property. The depreciated property hase includes installed battery and converter costs, plus $50 \%$ of halance-of-plant costs, less $50 \%$ of investment tax credits. The following expressions are used: 
- Depreciated property hase = $(1$ - invest ment tax credit rate/2) * (battery cost + converter cost + (1/2 kalance of plant cost)).

- Depreciation Expense

$$
\begin{aligned}
\text { Year } 1= & \text { depreciation property base * } \\
& 0.15 \\
\text { Year } 2= & \text { depreciation property base * } \\
& 0.22 \\
\text { Year } 3= & \text { depreciation property base * } \\
& 0.21 \\
\text { Year } 4= & \text { depreciation property base * } \\
& 0.21 \\
\text { Year } 5= & \text { depreciation property base * } \\
& 0.21
\end{aligned}
$$

Total Expenses -

Taxable Income -

Income Taxes -

Investment Tax Credits -
Calculated by sumining energy charge increase, annual ORl cost, auxiliary power cost, and tax depreciation.

Calculated by taking total savings and subtracting total expenses.

Calculater by taking the product of taxable income and the effective income tax rate.

Calculated by taking the product of the investment tax credit rate and the summation of total installed hattery and converter costs plus $1 / 2$ the balance of plant costs. The following expression is used:

Investment tax credit rate * (battery cost + converter cost $+1 / 2 *$ balance of plant costs).

\section{7}




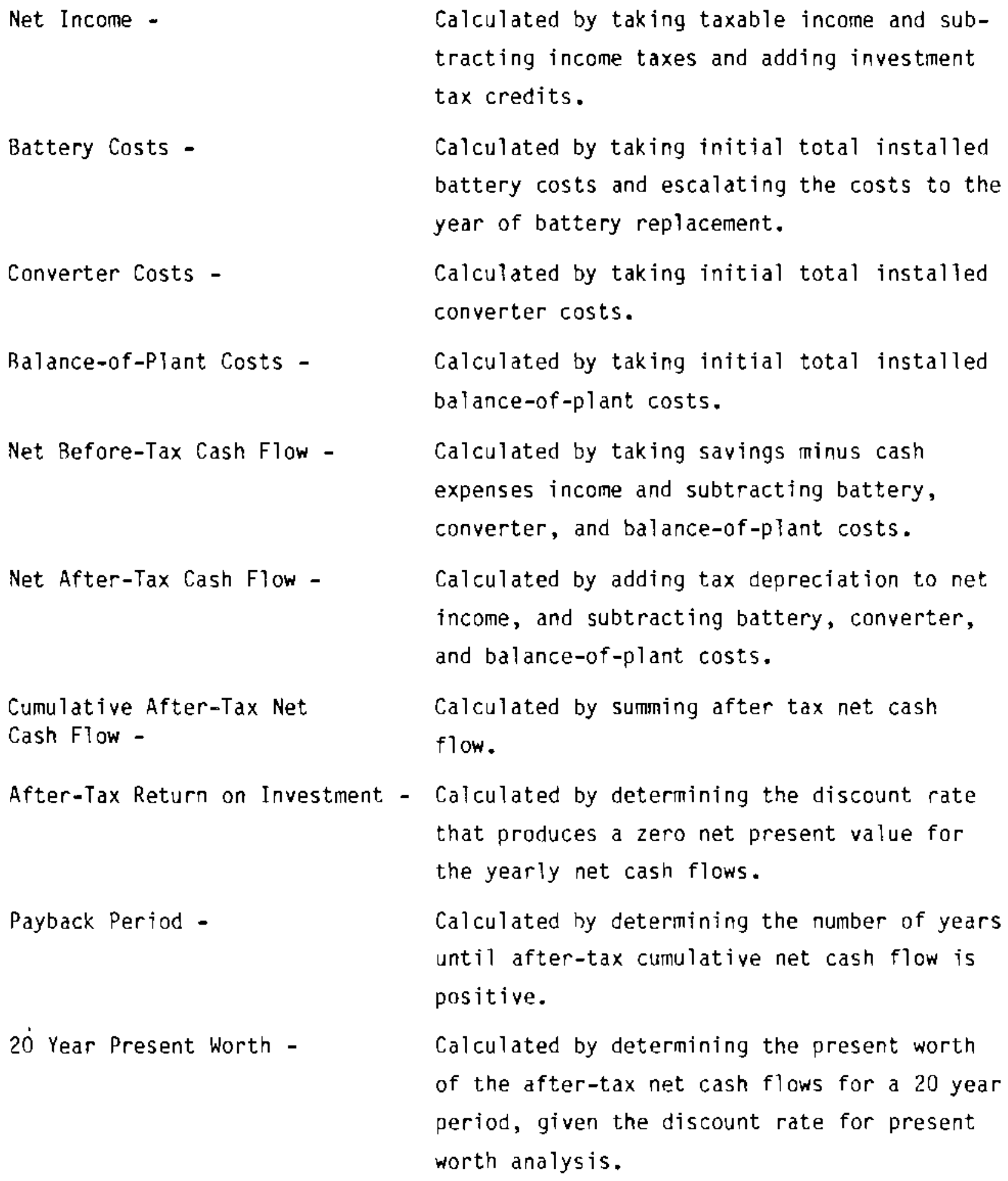

Calculated by taking taxable income and subtracting income taxes and adding investment tax credits.

Calculated by taking initial total installed battery costs and escalating the costs to the year of battery replacement. Calculated by taking initial total installed converter costs.

Calculated by taxing initial total installed balance-of-plant costs.

Calculated by taking savings minus cash expenses income and subtracting battery, converter, and balance-of-plant costs. Calculated by adding tax depreciation to net income, and subtracting battery, converter, and balance-of-plant costs. Calculated by sumning after tax net cash flow.

Calculated by determining the discount rate that produces a zero net present value for the yearly net cash flows.

Calculated by determining the number of years until after-tax cumulative net cash flow is positive.

Calculated by determining the present worth of the after-tax net cash flows for a 20 year period, given the discount rate for present worth analysis. 
APPENDIX A

MODEL VERIFICATIDN 


\section{APPENDIX A}

\section{MODEL VERIFICATION}

This chapter presents a check of the computer calculated values contained in SYSPLAN's economic analysis summary report. Hand calculations are based on the definitions provided in Chapter 3.n. These calculations for the first five years of system operation use the input data shown in Figure A.1, and adequately verify the corresponding computer calculated output values included in Figure A.2. All costs are in thousands of dollars.

DEMAND CHARGE REDIJCTION

TYearly sum of monthly peaked shaved * on-peak demand charge - (charge discharge ratio * off-peak demand charge)] * demand charge compounded escalation rate.

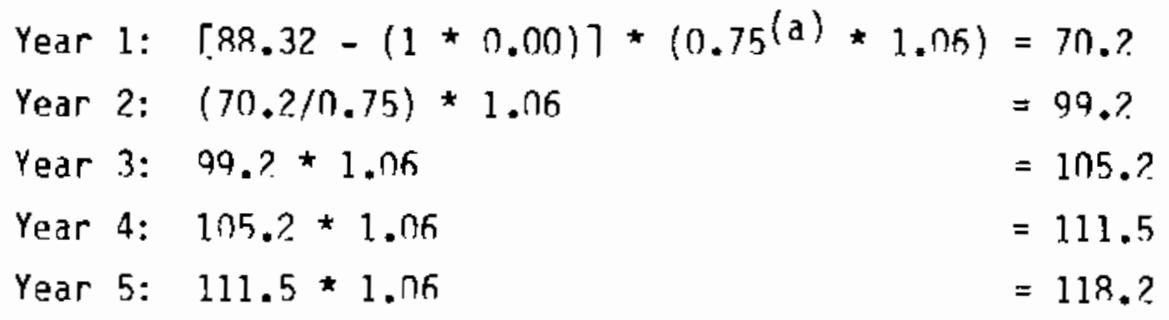

(a) 0.75 is the fraction of first year on line. 


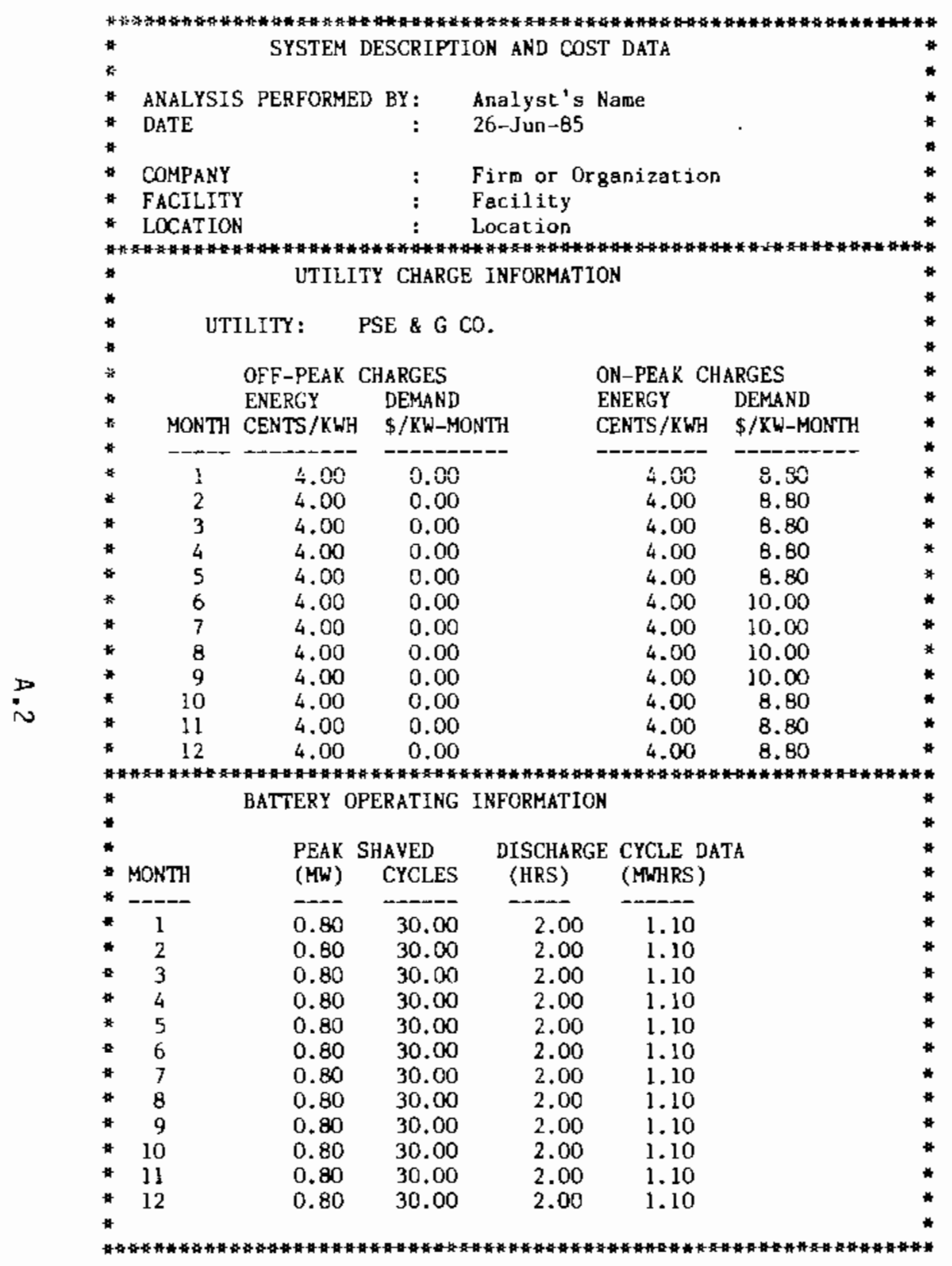

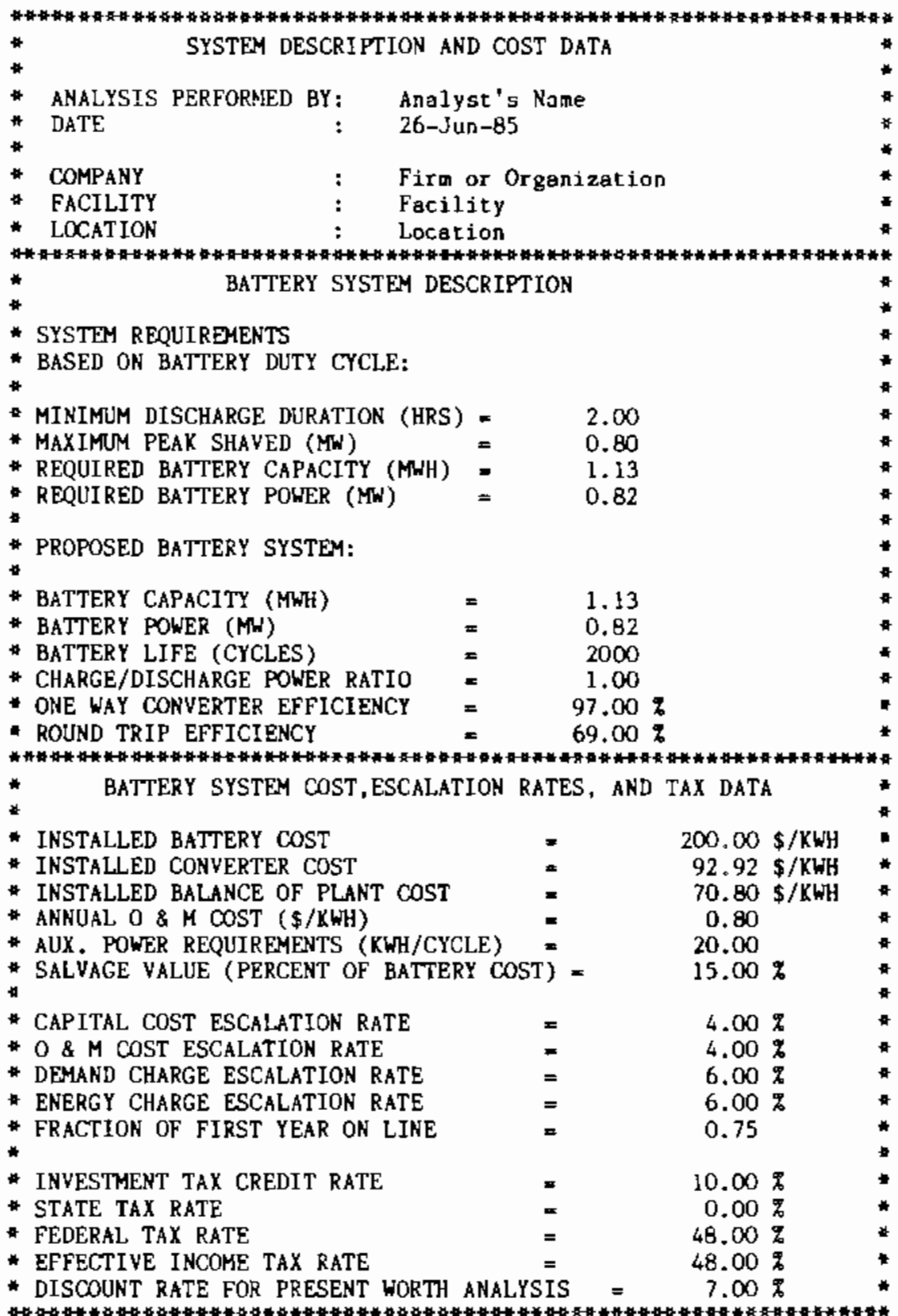

FIGURE A.1. 
SYSPLAN ECONOMIC ANALYSIS SUMMARY

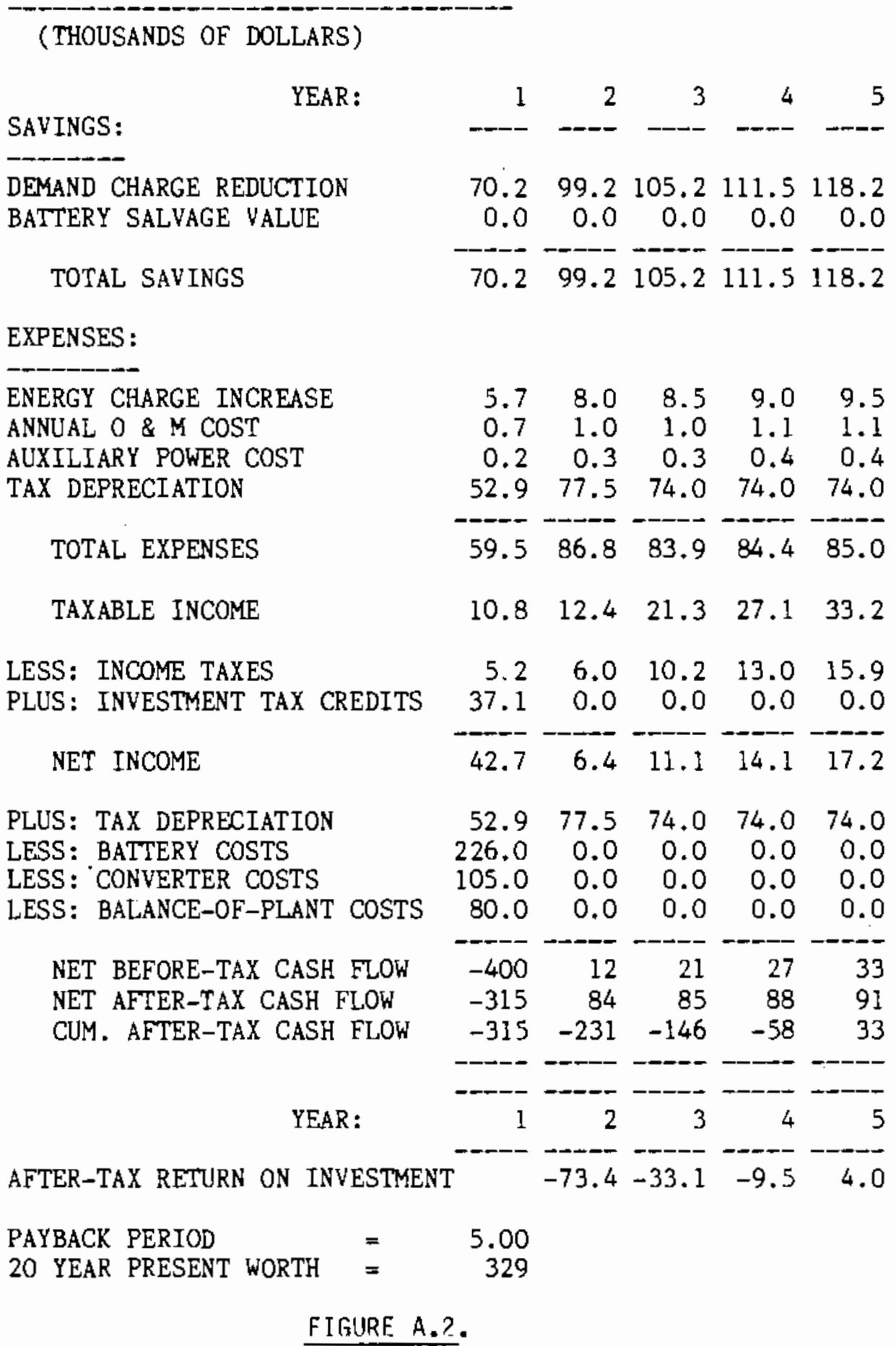


BATTERY SALVAGE VALUE

Product of battery replacement costs for the year when battery end of $1 \mathrm{ife}$ is reached * the salvage value expressed as a percent.

Year 1: $0 . n^{(a)}$

Year 2: 0.0

Year 3: 0.0

Year 4: 0.0

Year 5: 0.0

(a) No salvage value for those years as battery life $=6$ years

TOTAL SAVINGS

Sum of demand charge reduction and battery salvage value.

Year 1: $70.2+0.0=70 . ?$

Year ?: $99 . ?+0.0=99 . ?$

Year 3: $105.2+0.0=105 . ?$

Year 4: $111.5+0.0=111.5$

Year 5: $118.2+0.0=118 . ?$

ENERGY CHARGE INCREASE

Yearly sum of monthly Mh per discharge * number of cycles per month * [on-peak energy charge - (off-peak energy charge $\div$ round trip efficiency)] * compounded energy charge escalation factor * -1 .

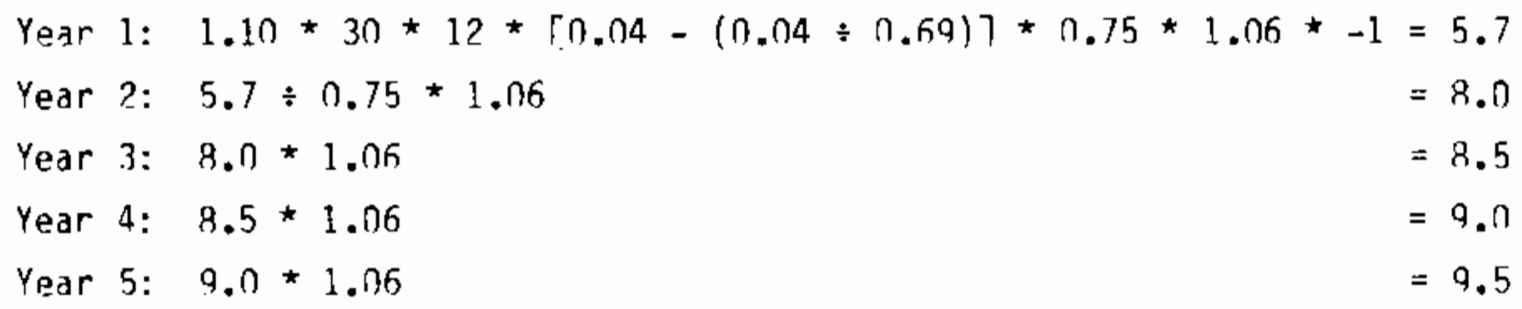


ANNUAL D\&M COST

Product of annual 0\&M cost in $\$ / \mathrm{kWh}$ * proposed battery capacity * compounded 0 \&M cost escalation factor.

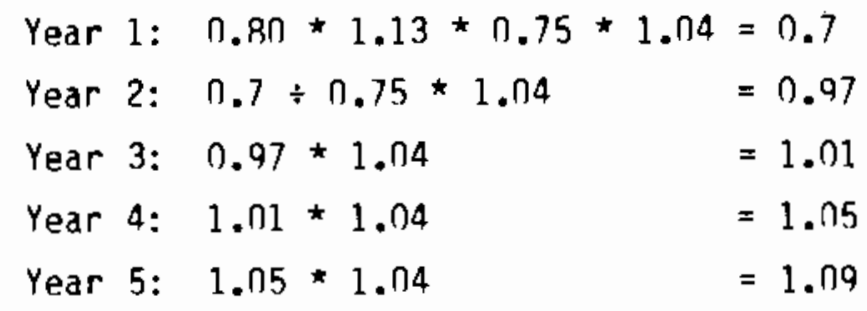

AUXILIARY POWER COST

Product of auxiliary power requirement in $\mathrm{kWh} / \mathrm{cycle}$ * the number of cycles per year * average off-peak energy cost * compounded energy escalation factor.

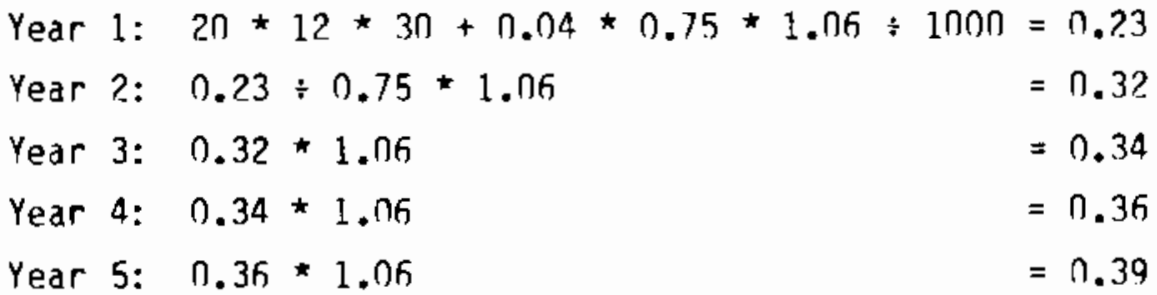

TAX OEPRECIATION

Depreciated property hase $=(1$ - investment tax credit rate $/ 2)$ * (battery cost + converter cost $+(1 / 2$ * halance-of-plant cost $))$.

Depreciation expense for

Year 1 = hase * 0.15

Year 2 = base $* 0.22$

Year 3 = base * 0.2 .1

Year 4 = base * $0 . ? .1$

Year 5 = hase $* 0 . ? 1$

Year 1: $(1-0.10 / 2) *(200 \star 1.13+92.92$

$\star 1.13+1 / 2 * 70.80 * 1.13) * 0.15=52.9$

Year 2: $352.45 * 0.22=77.5$ 
Year 3: $352.45 * 0.21$

Year 4: $352.45 * 0.21$

Year 5: $352.45 * 0.21$
$=74.0$

$=74.0$

$=74.0$

TOTAL EXPENSES

Sum of energy charge increase, annual ofM cost, auxiliary power cost, and tax depreciation.

Year 1: $5.7+0.7+0.23+52.9=59.5$

Year 2: $8.0+0.97+0.32+77.5=86.8$

Year 3: $8.5+1.01+0.34+74.0=83.9$

Year 4: $9.0+1.05+0.36+74.0=84.4$

Year 5: $9.5+1.09+0.39+74.0=85.0$

TAXARLE INCOME

Calculated by taking total savings and subtracting total expenses.

Year 1: $70.2-59.5=10.7$

Year ?: $99 . ?-86.8=17.4$

Year 3: $105.2-8.3 .9=2.1 .3$

Year 4: $111.5-84.4=? 7.1$

Year 5: $118.2-85.0=33.2$

INCOME TAXES

Product of taxable income * effective income tax rate.

Year 1: $10.7 * 0.48=5.14$

Year ?: $12.4 * 0.48=5.95$

Year 3: $21.3 * 0.48=10.22$

Year $4: 27.1 * 0.48=13.0$

Year 5: $33.2 * 0.48=15.93$ 


\section{INVESTMENT TAX CREOITS}

Investment tax credit rate * (hattery cost * converter cost $+1 / 2$ * balance-of-plant costs).

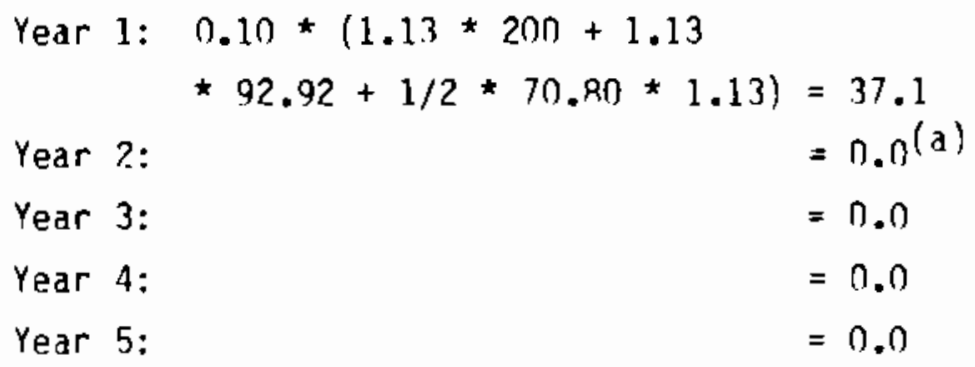

(a) No battery system costs for years? to 5 .

NET INCOME

Taxable income - income taxes + investment tax credits.

$$
\begin{aligned}
& \text { Year 1: } 10.7-5.14+37.1=42.66 \\
& \text { Year 2: } 12.4-5.95+0.0=6.45 \\
& \text { Year 3: } 21.3-10.22+0.0=11.08 \\
& \text { Year 4: } 27.1-13.0+0.0=14.1 \\
& \text { Year 5: } 33.2-15.93+0.0=17.27
\end{aligned}
$$

\section{TAX DEPRECIATION}

Same as previously calculated.
Year 1: 57.9
Year 2: 77.5
Year 3: 74.0
Year 4: 74.0
Year 5: 74.0 
Installed battery cost * system capacity. First year costs are not escalated.

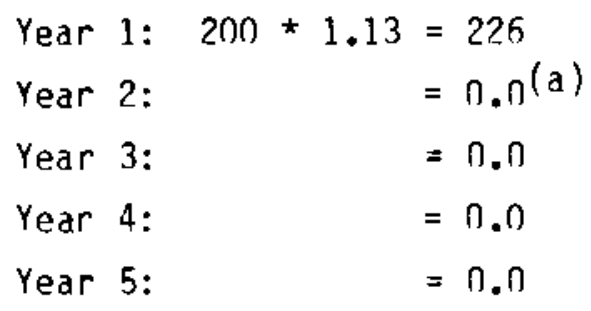

(a) No battery purchased in years 2 to 5 .

CONVERTER COST

Installed converter cost * system capacity. First year's cost is not escalated and the 1 ife of the converter is assumed to he greater than 20 years.

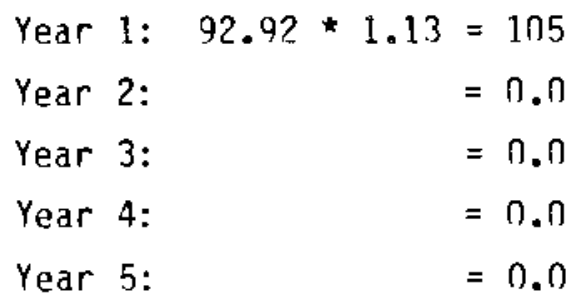

BALANCE-OF-PLANT COST

Installed balance of plant cost * system capacity. First year's cost is not escalated and the life of balance of plant equipment is assumed to be greater than 20 years.

$\begin{aligned} \text { Year 1: } & 70.80 * 1.13 & =80.0 \\ \text { Year 2: } & & =0.0 \\ \text { Year 3: } & & =0.0 \\ \text { Year 4: } & & =0.0 \\ \text { Year 5: } & & =0.0\end{aligned}$


Present worth $=-315+84 \star(0.9615)+85 *(0.9246)+88 *(0.8890)$

$+91 *(0.8548)=0.375$, or approximately zero

PAYBACX PERIOD

Number of years until cumulative after-tax net cash flow is positive.

Year 5: Cumulative after-tax cash flow $=33$

$\therefore$ Payback period $=5.00$ years

20 YEAR PRESENT WORTH

Present worth of the net cash flows for a 20 year period, given the discount rate for the present worth analysis.

a at discount rate of 7.00 percent:

Year 1 present worth $=-315 *(0.9345)$

Year 2 present worth $=84 *(0.8734)$

Year 3 present worth $=85 \star(0.8163)$

Year 4 present worth $=88 *(0.7529)$

Year 5 present worth $=91 *(0.7130)$

Year 6 present worth $=-150 *(0.6664)$

Year 7 present worth $=90 *(0.6228)$

Year 8 present worth $=93 \star(0.5820)$

Year 9 present worth $=97 *(0.5439)$

Year 10 present worth $=101 *(0.5084)$

Year 11 present worth $=-175 *(0.4751)$

Year 12 present worth $=118 *(0.4440)$

Year 13 present worth $=121 *(0.4150)$

Year 14 present worth $=127 \star(0.3878)$

Year 15 present worth $=132 \star(0.3625)$

Year 15 present worth $=-204 *(0.3397)$

Year 17 present worth $=154 *(0.3166)$

Year 18 present worth $=158 *(0.2959)$

Year 19 present worth $=166 *(0.2765)$ 
Year 20 present worth $=173 \star(0.2584)$

Total present worth $=328.28$ or approximately 329 thousand

A. 11 
.

.

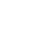

. 
APPENDIX B

TECHNICAL DOCUMENTATION FOR XSIZE SIZING MODEL 


\section{APPENDIX B}

TECHNICAL DOCUMENTATION FOR XSIZE SIZING MODEL

The documentation in this appendix is not needed for normal use of the XSIZE sizing routine but rather for those who wish to modify the spreadsheet. It includes a spreadsheet map, a description of the cell protection used, hardcopy of selected formulas, and details of the macro programs used.

A spreadsheet map for XSIZE is shown as Figure R.1. In this map, the different areas of the spreadsheet are labeled by their purpose. In addition, the cell locations of each area are included.

\section{CELL PROTECTION}

Cell protection is the defautt in XSIZE, with cells unprotected only as needed. Cells into which users enter data are all unprotected. In the calculation workspace area, the "selected table" cells are unprotected so that they can be copied and shown to users elsewhere in the spreadsheet. Finally, a few cells have been unprotected so that they are highlighted on the screen; these contain important instructions for the user.

If the XSIZE spreadsheet is altered, it is likely that the cell protection scheme also will need to be modified.

\section{SPREAISHEET FORMULAS}

Much of the XSIZE worksheet contains instructions and explanations for users, with a few cells used for data entry. XSIZE contains only a few for:ilus which are evaluated to ohtain results. These are shown below.

Formulas are found in four parts of the worksheet. The limiting size range displayed to the user is calculated from the selected range cells in the calculation workspace. These formulas, in turn, are based on the "selected table," which is selected and copied by the ALT F macro. 


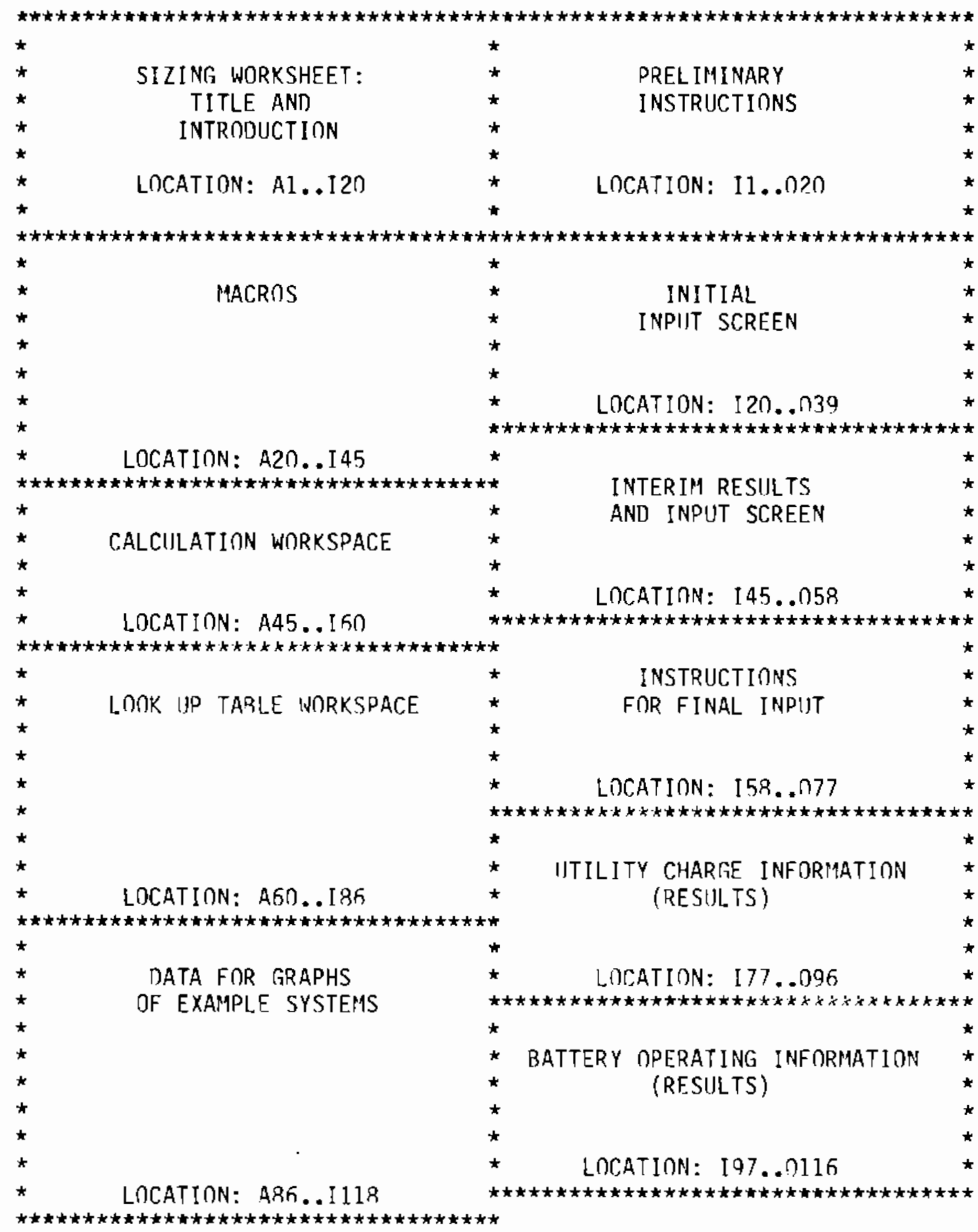

FIGURE B.1. XSIZE Spreadsheet Map 
Formulas are also used in the utility charge and battery operating information screens. These formulas are written to the proper cells by the ALT 0 macro and then evaluated. This is done so that the user can enter other values later. The utility charge formulas copy the charge data entered earlier by the user, while battery operating and formulas are based upon the discharge duration and power level also entered by the user.

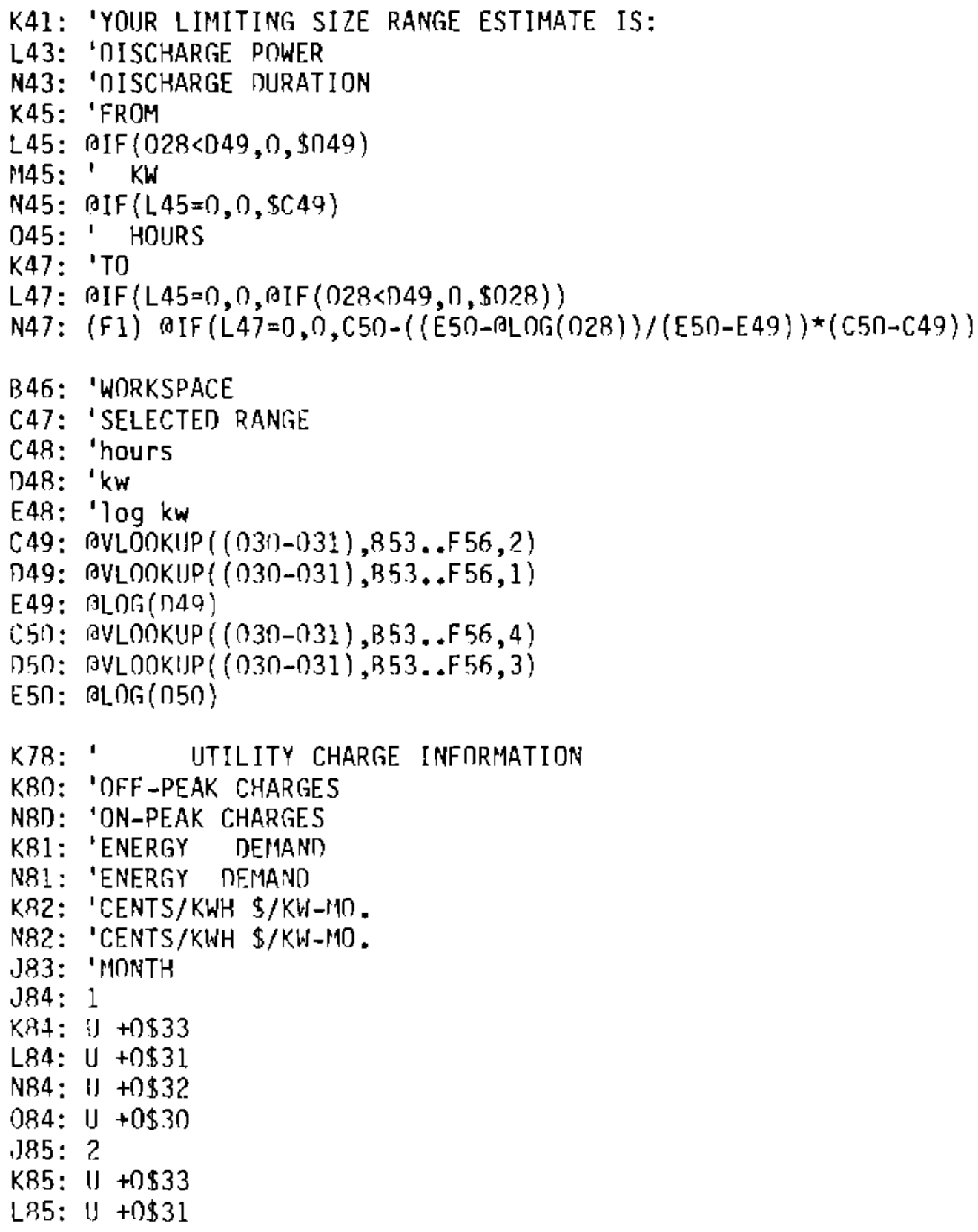


N85: $U+0 \$ 32$

085: $U+0 \$ 30$

K97: ' BATTERY OPERATING INFORMATION

K99: ' PEAK SHAVET

M99: 'DISCHARGE CYCLE DATA

K100: "MW

L100: "CYCLES

M100: "HOURS

N100: "MWH

J101: "MONTH

J1ก2: 1

K102: U +0\$54/1000

L102: $\cup$ '

M102: U +0\$53

N102: U +K102*+1102/?

1103: ?

K103: $11+0 \$ 54 / 1000$

L103: U '

M103: $U+0 \$ 53$

N103: U +K103*M103/2

MACROS

Size estimates are arrived at in XSIZE by the execution of a series of macro programs. These macros are listed and described in Table R.1, where they are shown in the order in which the user executes. 
TABLE B.1. XSIZE macros

\begin{tabular}{|c|c|c|}
\hline $\begin{array}{l}\text { Range } \\
\text { Name }\end{array}$ & Macro & Description \\
\hline$\backslash A$ & $\begin{array}{ll}\text { B22: } & \text { 'ALT A } \\
\text { D22: } & \text { MOVES TO INTRODUCTDRY SCREEN } \\
\text { C22: ' } & \text { HOME }\}\{\text { GOTO } J 1 \sim\{\text { LEFT }\}\end{array}$ & $\begin{array}{l}\text { Displays the initial } \\
\text { instructions screen to } \\
\text { inform the user how to } \\
\text { begin data entry. }\end{array}$ \\
\hline$\backslash B$ & $\begin{array}{l}\text { B29: 'ALT B } \\
\text { D29: ' VIEW GRAPH } \\
\text { C29: '/gnUCOMMUTER q }\end{array}$ & $\begin{array}{l}\text { Displays the example graph } \\
\text { COMMUITER. }\end{array}$ \\
\hline$\backslash C$ & $\begin{array}{l}\text { B31: 'ALT C } \\
\text { D31: ' VIEW GRAPH } \\
\text { C31: '/gNUMACHINE q }\end{array}$ & $\begin{array}{l}\text { Displays the example graph } \\
\text { MACHINE. }\end{array}$ \\
\hline$\backslash 0$ & $\begin{array}{ll}\text { B43: } & \text { 'ALT } 0 \\
\text { D43: } & \text { ENTER CHARGES, PEAK FOR CALCULATIONS } \\
\text { C43: } & \text { \{HOME }\}\{\text { GOTO }\} I 21 \sim\{\text { UP }\} / r i I 20 . .039 \sim\end{array}$ & $\begin{array}{l}\text { Displays the screen where } \\
\text { users enter peak and } \\
\text { charge information, then } \\
\text { pauses for user input. }\end{array}$ \\
\hline$\backslash E$ & 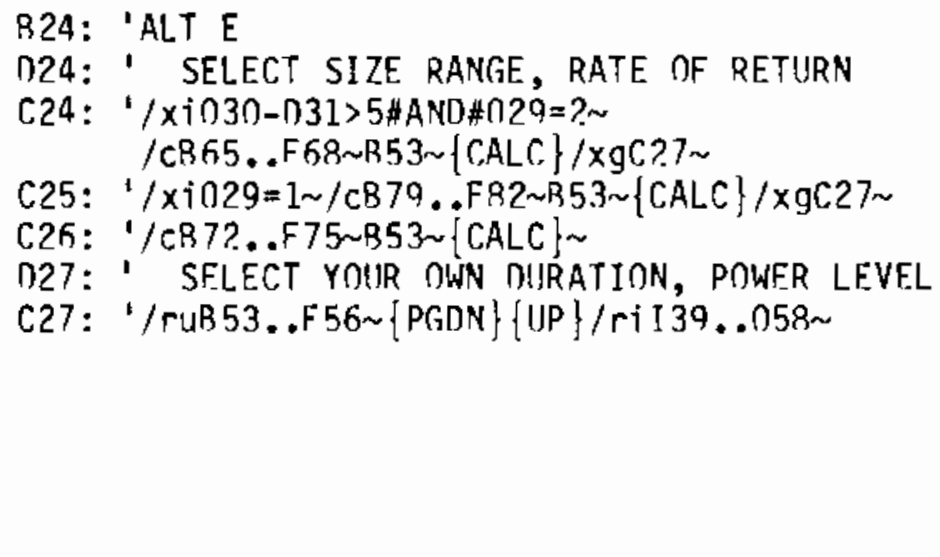 & $\begin{array}{l}\text { Depending upon the entered } \\
\text { values for rate type and } \\
\text { demand charges, this macro } \\
\text { selects one of three pos- } \\
\text { sible size ranges and cop- } \\
\text { ies it to the "selected } \\
\text { table" area of the work- } \\
\text { sheet. The }\{\text { CALC\} } \\
\text { instruction copies the } \\
\text { size range to the interim } \\
\text { results screen, where the } \\
\text { user may view and alter } \\
\text { it. }\end{array}$ \\
\hline$\backslash F$ & $\begin{array}{l}\text { B33: }: \text { ALT F } \\
\text { D33: } \quad \text { GO TO INSTRUCTION SCREEN FOR PASS } \\
\text { TARLES } \\
\text { C33: }\end{array}$ & $\begin{array}{l}\text { Displays the final } \\
\text { instruction screen, } \\
\text { (where users are directed } \\
\text { to use ALT 0 to create } \\
\text { pass file information). }\end{array}$ \\
\hline
\end{tabular}


TABLE 8.1. Contd

\begin{tabular}{|c|c|}
\hline $\begin{array}{l}\text { Range } \\
\text { Name }\end{array}$ & Macro \\
\hline 10 & 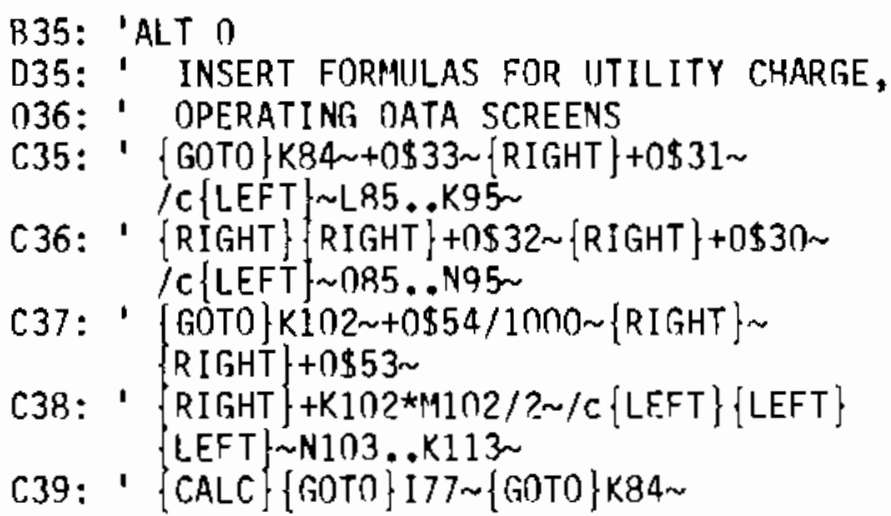 \\
\hline$\backslash p$ & $\begin{array}{ll}\text { B41: } & \text { ALT } P \\
\text { D41: } & \text { SAVE FILE FOR SYSPLAN } \\
\text { C41: } & \text { / fXVSIZE K84..0113 r }\end{array}$ \\
\hline
\end{tabular}

\begin{tabular}{l} 
Description \\
\hline Creates the screens con- \\
taining utility charge and \\
battery operating infor- \\
mation. To do this, \\
appropriate formulas are \\
inserted in the proper \\
cells, then copied to \\
other cells. The (CALC) \\
instruction causes cur- \\
rent values to be evalu- \\
ated for the two screens, \\
which are then displayed \\
to the user. \\
Extracts data from the \\
utility charge and \\
operating information \\
screens, then saves it to \\
the file SIZE. WKS, which \\
can he retrieved hy the \\
SySPLAN model.
\end{tabular}




\section{APPENDIX C}

TECHNICAL DOCUMENTATION FOR SYSPLAN COST MODEL 
APPENDIX C

TECHNICAL DOCUMENTATION FOR SYSPLAN COST MONEL

The documentation included in this appendix should not be needed for normal use of the SYSPLAN spreadsheet. It is included mainly as an aid to Lotus 123 programmers who wish to make changes to the spreadsheet. The appendix includes a description of the cell protection scheme used, a map of the spreadsheet, hardcopy of selected formulas, printouts and explanations of macro programs, and a description of some of the Lotus 123 ranges used in SYSPLAN.

The spreadsheet map is shown in Figure C.1. It is similar to the map presented earlier in this document as Figure 2.1, but also includes the cell locations of the various input screens and output areas.

\section{CELL PROTECTIDN}

In the current version of the SYSPLAN spreadsheet, cell protection is the default; the entire spreadsheet is protected, and cells or ranges are unprotected as needed. If the SYSPLAN spreadsheet is changed, it is likely that changed cells will have to he protected or unprotected.

On the input screens (accessed by the ALT-A macro and custom menu INPTMEN(J), only those cells containing user-entered information are unprotected.

Several items on the sensitivity analysis screen are unprotected. Unprotected cells include those containing the name of the independent variable, and its minimum and maximum values. The tahle of independent and dependent variahle values is also unprotected.

The remainder of the SYSPLAN spreadsheet (the Main Menu, F.conomic Analysis Summary, Key Economic Performance Measures, workspace and macros) is protected. 


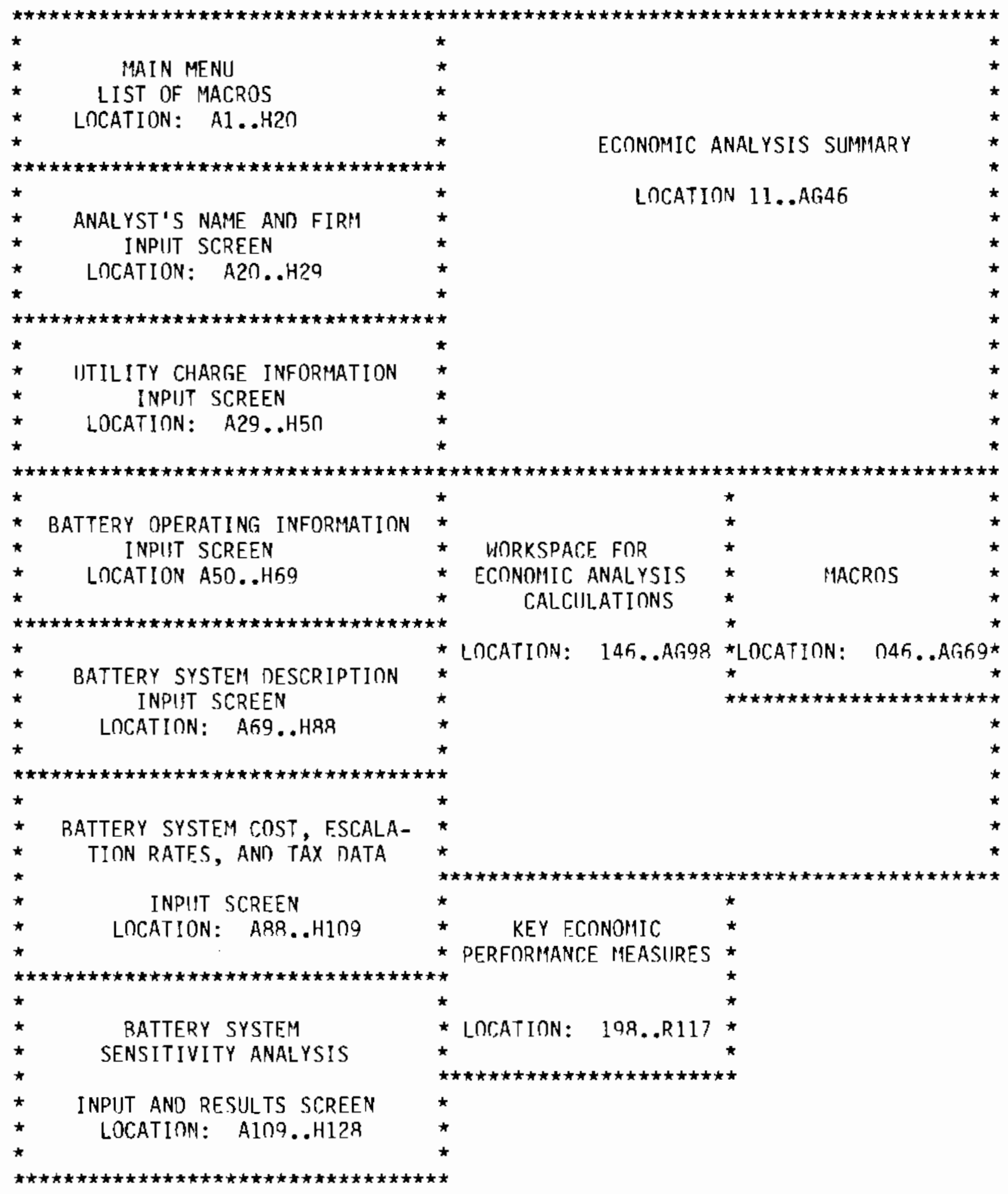

FIGURE C.1. SYSPLAN Spreadsheet Map 
SPREADSHEET FORMULAS

Selected formulas from the SYSPLAN spreadsheet are shown on the following pages; they are accompanied by the cell labels that identify them.

The only formulas shown from the input screens are those calculated items that are not entered by the user. These are the hattery system requirements figures, and the effective income tax rate.

The lahel for each item in the Economic Analys is Summary is shown, along with the formula(s) for its calculation for the first one or two years. The calculations for many of the economic analysis numbers differ for the first and subsequent years. When they differ, the formulas for both the first and second years of the analysis are shown. When the calculations for all years are the same, only the first year is shown.

Lahels and formulas are shown for all items included in the Key Economic Performance Measures area of the spreadsheet. These items are copied from other parts of the spreadsheet so that the user can view them all on one screen.

The workspace area of the spreadsheet contains items calculated for each month of the year and items calculated for each year of the analysis. Formulas for the first two months or for the first two years are included. The depreciation calculations occupy a 20 by 20 matrix of cells within the workspace. For this series of calculations, formulas from a 2 by 6 segment from the upper left corner of the larger matrix are shown. Other formulas included from the workspace are hattery life in years, payback period calculations and scaling calculations for the FLOW (cumulative cash flow) and NETCF (net cash flow) graphs.

C70: ' RATTERY SYSTEM DESCRIPTION

B72: 'SYSTEM REOUIREMENTS

B73: 'BASET ON RATTERY DIITY CYCLE:

B75: 'MINIMUM DISCHARGE MITRATION (HRS) =

F75: OMIN(E56..E67)

B76: "MAXIMIM PEAK SHAVEN (MW) =

F76: AMAX (C56..C67)

B77: 'REOUIRED BATTERY CAPACITY (MWH) =

F77: (F2) OMAX (F56..F67)/F86*1 N0

R78: 'REOUIREO RATTERY POWER (NW) =

$F 7 R:(F 2)+F 76 / F 96 \star 100$ 


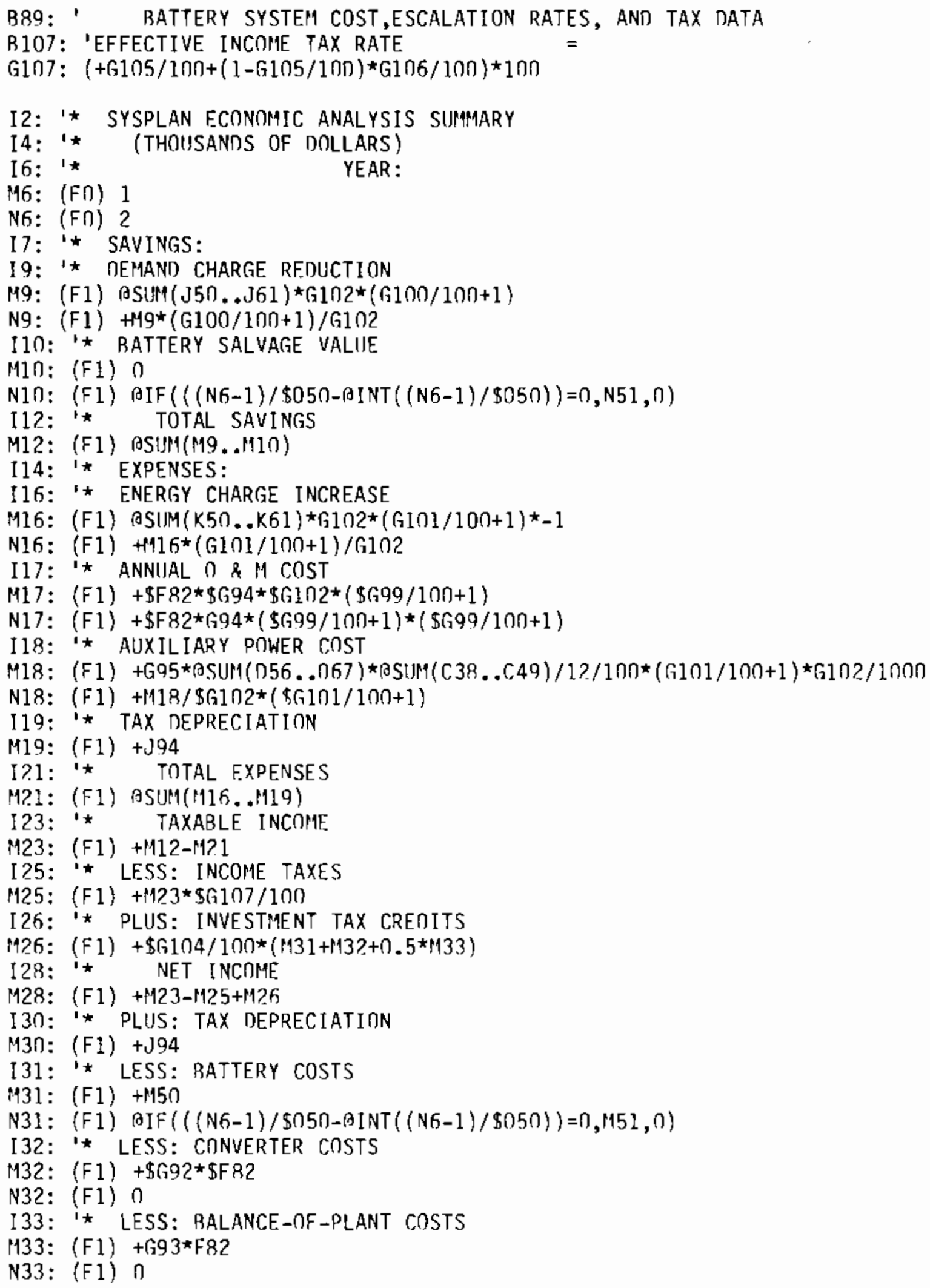




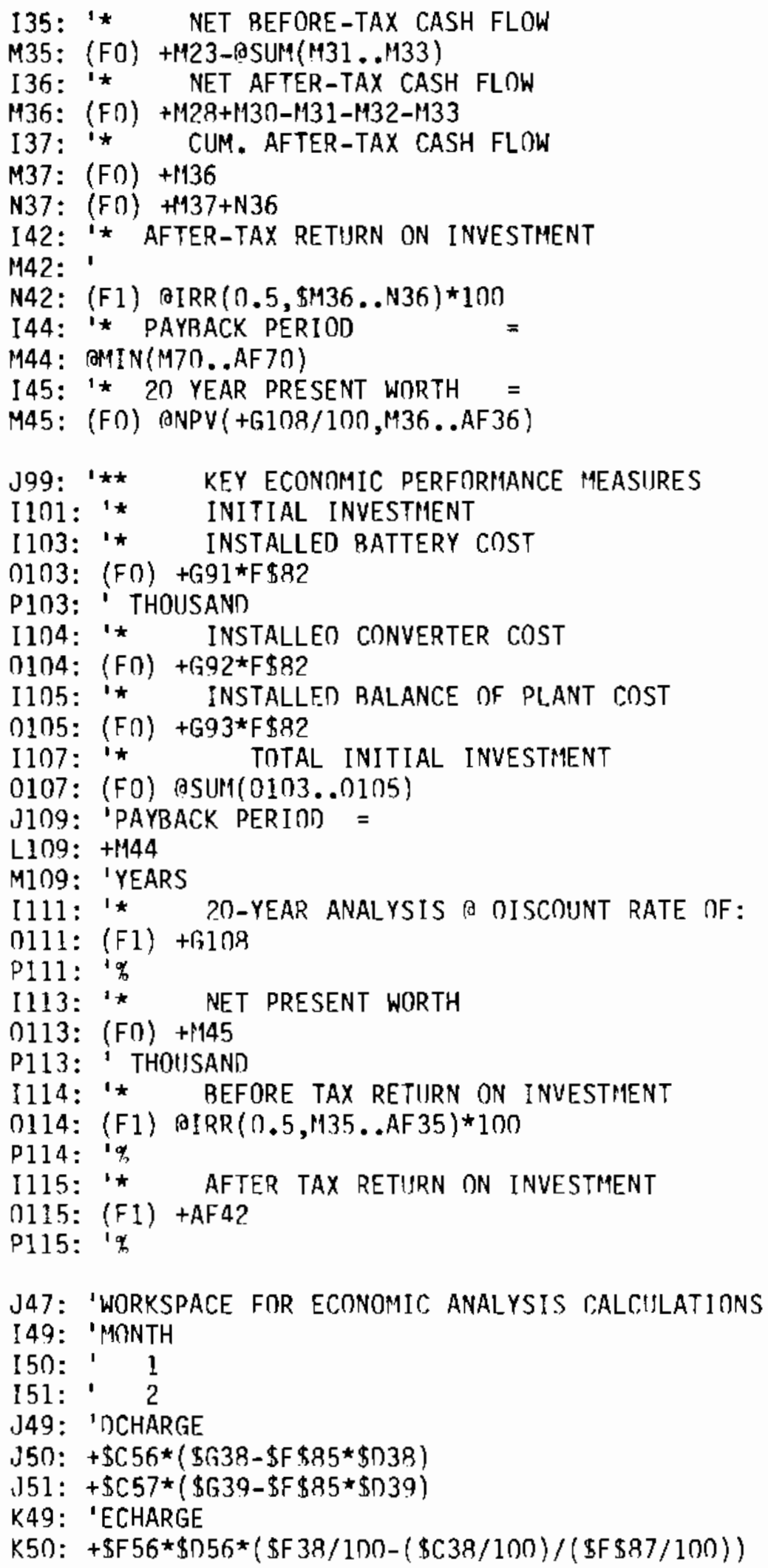




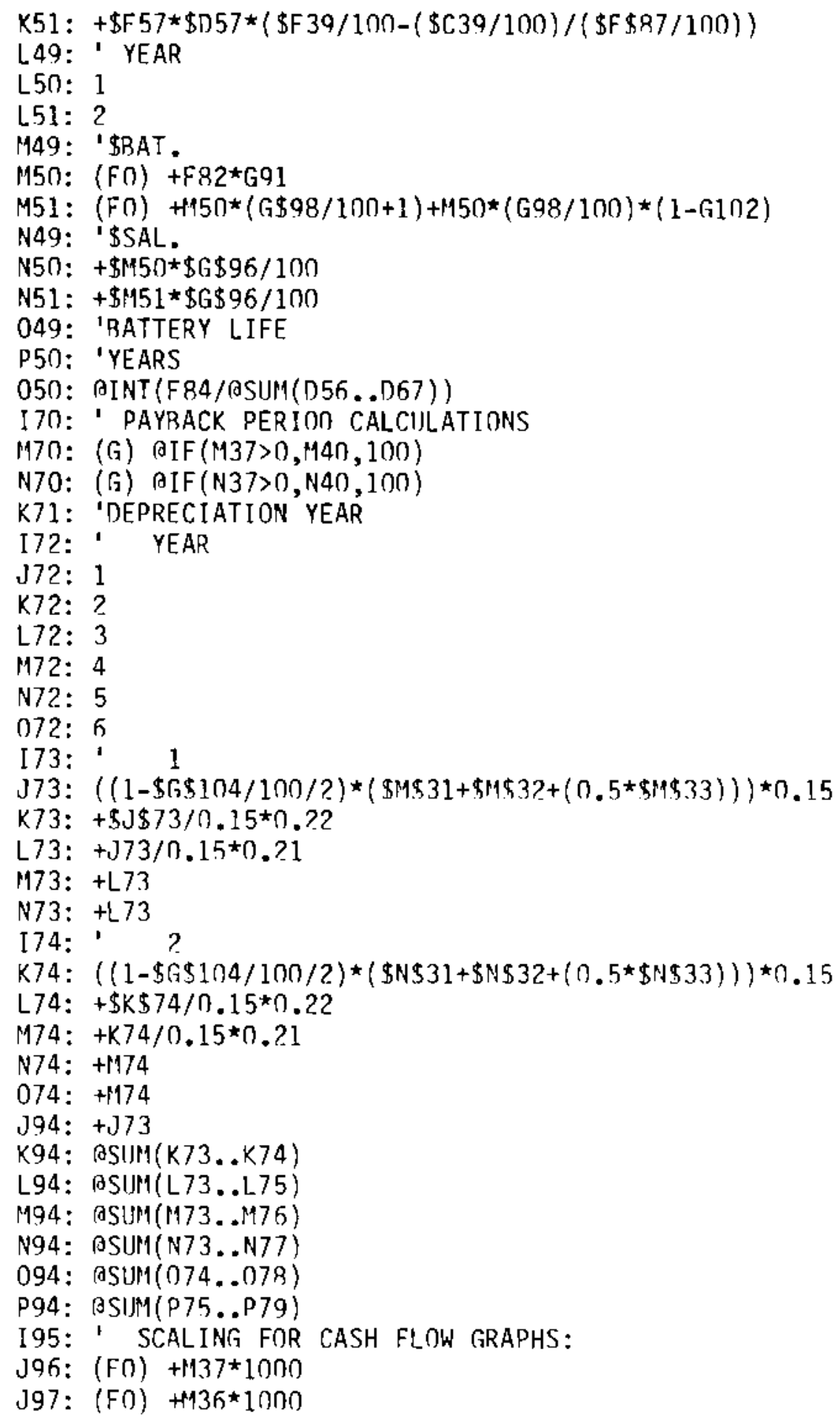




\section{MACROS AND RANGES}

The SYSPLAN spreadsheet includes several macro programs, including two that call custom menus. The macros that do not call custom menu allow for output and graphs to he viewed, and for the printing of reports. One custom menu (INPTMENU) allows for data input by the user, the other (SENSMENU) for specifying and calculating sensitivity analysis tables. A third custom menu, INDEMENI, is called directly from the SENSMENU menu, and allows independent variables to be specified for sensitivity analyses.

Table C.1 gives a description of each macro listed in SYSPLAN's main menu. Table C.2 lists the options available from the INPTMENU custom menu (data input). The menu options for sensitivity analyses are described in TabTes C.3 (SENSMENU) and C.4 (INMEMENU). Fach includes the range names, where applicable, and copies of the macro codes and descriptions of each.

The sensitivity analysis features also make use of several named ranges. These are listed and described in Table C.5. 
TABLE C.1. Description of SYSPLAN Macros

\begin{tabular}{|c|c|}
\hline $\begin{array}{l}\text { Range } \\
\text { Name }\end{array}$ & Macro \\
\hline$\backslash A$ & 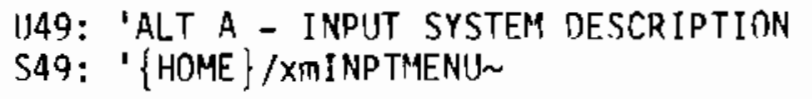 \\
\hline$\backslash B$ & $\begin{array}{l}\text { U51: 'ALT B - VIEW SUMMARY } \\
\text { S51: '\{HOME }\}\{\text { GOTO }\} \text { I } \sim\end{array}$ \\
\hline$\backslash C$ & $\begin{array}{l}\text { 1S53: 'ALT C - VIEW NET CASH FLOW GRAPH } \\
\text { S53: ' } / \text { gNUNETCF } \sim \mathrm{q}\end{array}$ \\
\hline$\backslash D$ & $\begin{array}{l}\text { U55: 'ALT D-VIEW CUM.CASH FLOW GRAPH } \\
\text { S55: '/gnUFLOW q }\end{array}$ \\
\hline$\backslash E$ & $\begin{array}{l}\text { U57: 'ALT E - PRINT SYSTEM DESCRIPTION } \\
\text { S57: '/ppohrA20..H28 q } \\
\text { S58: 'rA29..H69 gp } \\
\text { S59: 'rA69..H109 gpebq }\end{array}$ \\
\hline$\backslash F$ & 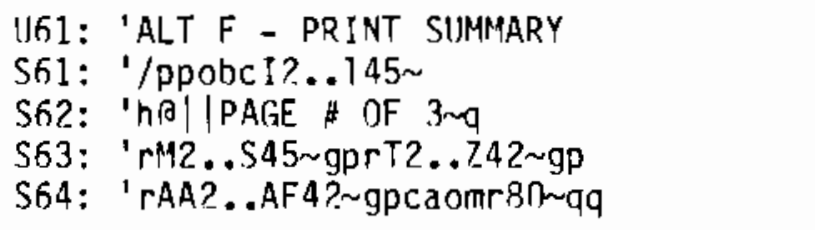 \\
\hline$\backslash G$ & $\begin{array}{l}\text { U66: 'ALT G - SENSITIVITY ANALYSES } \\
\text { S66: '\{HOME\} \{GDTO\}A109 } \\
\text { S67: '/XmSENSMENU }\end{array}$ \\
\hline$\backslash \mathrm{H}$ & $\begin{array}{l}\text { W54: 'ALT H - VIEW PERFORMANCE MEASURES } \\
\text { W55: '\{HOME }\} \text { GOTO\} I98 }\end{array}$ \\
\hline
\end{tabular}

Description
Calls the INPTMENu custom
menu for data input.
Moves to the top left hand
corner of the Economic
Analys is Summary.
Calls up the NETCF graph to
view Net Cash Flow.
Calls up the FLOW graph to
view Cumulative Cash Flow.
Sets horders for the System
Description report, prints
the appropriate ranges,
clears horders and guits.
Sets borders and header for
the Economic Analysis Sum-
mary, prints the appropriate
ranges, clears all options
and quits.
Calls the SENSMENi custom
menu for sensitivity
analyses.
Moves to the Key Economic
Performance Measures screen.


TABLE C.2. Description of Custom Menu INPTMENU

\begin{tabular}{|c|c|}
\hline $\begin{array}{l}\text { Range } \\
\text { Name }\end{array}$ & Macro \\
\hline \multirow[t]{3}{*}{ INPTMENIJ } & (Located in cells Y4R..AF49) \\
\hline & 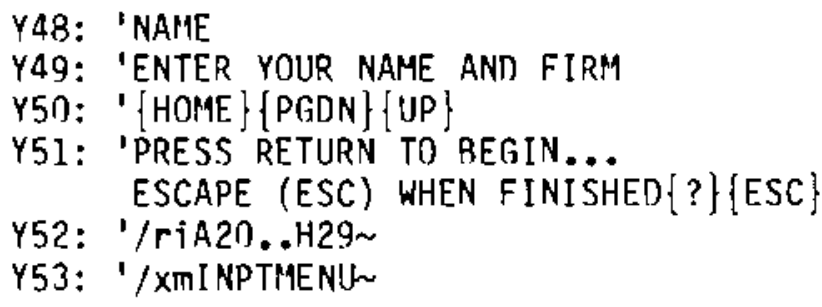 \\
\hline & 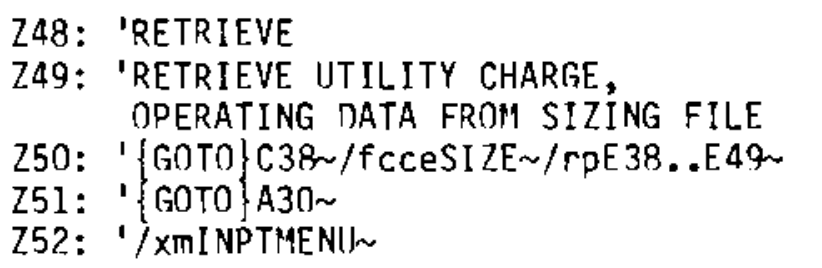 \\
\hline
\end{tabular}

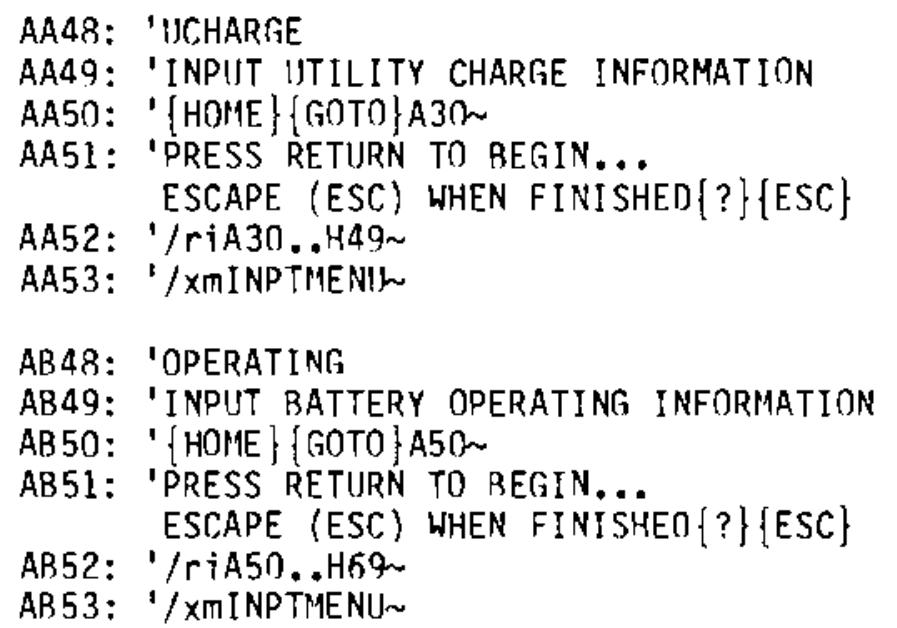

Positions the pointer, retrieves the SIZE pass file from the sizing worksheet into the appropriate sections of SYSPLAN (utility charge and operating screens), and returns to [NPTMENI.

Positions the pointer, displays a prompt, allows for input or editing of itility charge information, then returns to INPTMENI.

Positions the pointer, displays a prompt, allows for input or editing of hattery operating information, then returns to INPTHENIJ. 
TABLE C.2. Contd

\begin{tabular}{|c|c|c|}
\hline $\begin{array}{l}\text { Range } \\
\text { Name }\end{array}$ & Macro & Description \\
\hline & 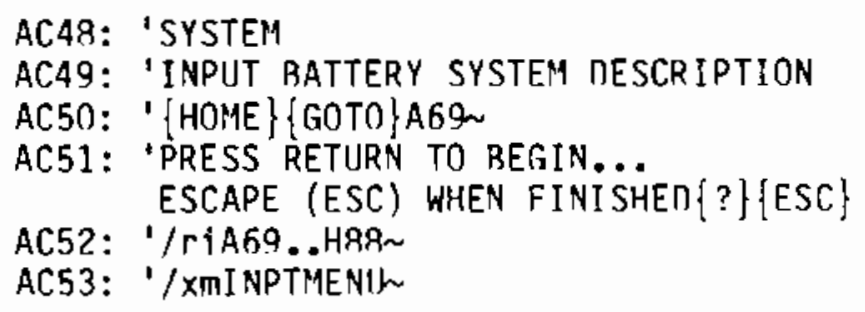 & $\begin{array}{l}\text { Positions the pointer, } \\
\text { displays a prompt, dliows } \\
\text { for input of a battery } \\
\text { system description, then } \\
\text { returns to INPTMENIS. }\end{array}$ \\
\hline & 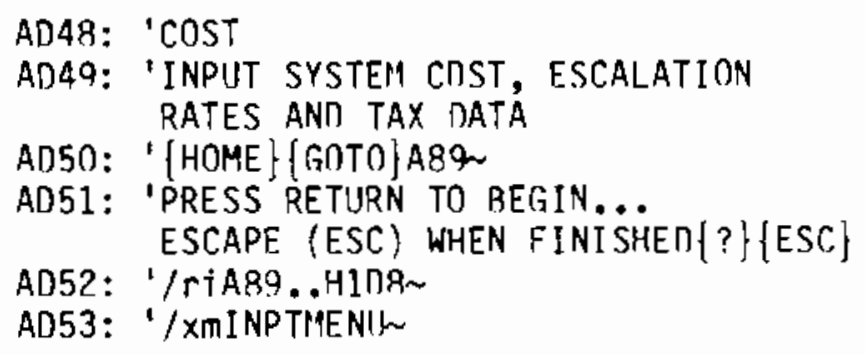 & $\begin{array}{l}\text { Positions the pointer, } \\
\text { displays a prompt, allows } \\
\text { for input of system cost, } \\
\text { escalation rates and tax } \\
\text { information, then returns } \\
\text { to INPTMENII. }\end{array}$ \\
\hline & $\begin{array}{ll}\text { AE48: } & \text { 'OUIT } \\
\text { AE49: 'RETURN TO MAIN MENU } \\
\text { AE50: }\{\text { HOME }\}\end{array}$ & $\begin{array}{l}\text { Exits from INPTMENU and } \\
\text { returns to the Main Menu. }\end{array}$ \\
\hline
\end{tabular}


TABLE C.3. Description of Custom Menu SENSIENU

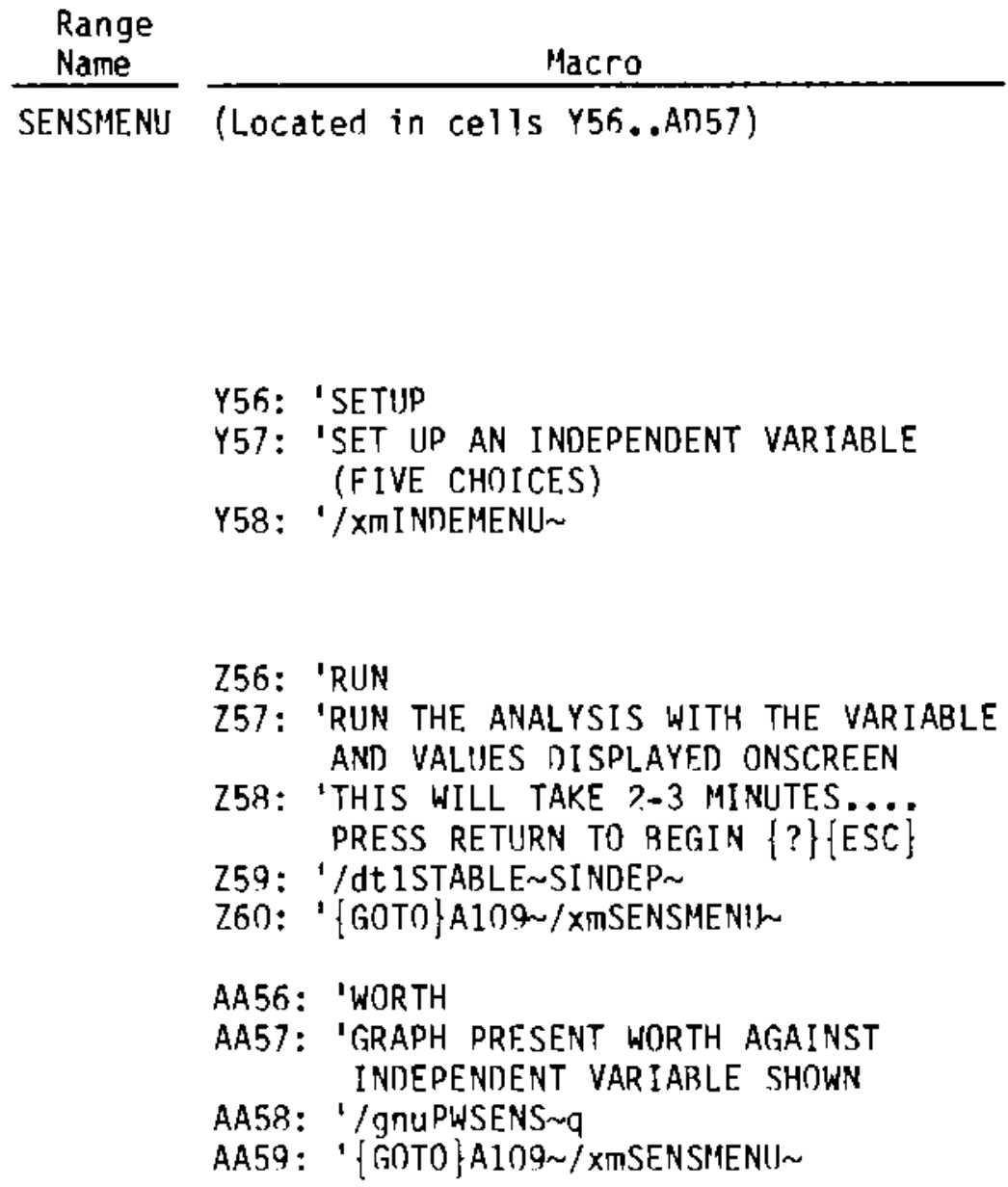

AR 56: 'GPAYBACK

AB57: 'GRAPH PAYBACK PERIOD AGAINST INDEPENDENT VARIABLE SHOWN

AR58: $1 /$ gnUPPSENS q

AB59: '\{GOTO\}A109 /XmSENSMENU

AC56: 'PRINT

AC57: 'PRINT THE ANALYSIS RESULTS

AC58: '/PprA2ก..H28 G

AC59: ' $r A 109$. H116 grA118. .H128 gpq

AC60: ' $\{$ GOTO $\} A 109 \sim / X M S E N S M E N U \sim$

AD56: 'DUIT

AD57: 'RETIRN TO THE MAIN MENU

An58: ' HOME $\}$

Description

Custom menu SENSMENU encompasses the options listed below. It is originaliy called by the ALT-G macro, and is used for performing sensitivity analyses.

Calis subsidiary menu INDEMENU, which allows users to select one of five possible independent variables for sensitivity analyses.

Displays a message, calculates a sensitivity analys is table in the range STABLE using the input value SINDEP, then returns to SENSMENU.

Calls up the PWSENS graph, which plots the present worth of the battery system against the values of the current independent variable.

Calls up the PPSENS graph, which plots the payback period of the battery system against the values of the current independent variable.

Sets borders for the sensitivity analysis report, prints the appropriate range, clears the horders and returns to SENSMENIJ.

Exits from SENSMENIJ and returns to the Main Menu. 
TABLE C.4. Description of Custom Menu INDEMENU

\begin{tabular}{|c|c|c|}
\hline $\begin{array}{l}\text { Range } \\
\text { Name }\end{array}$ & Macro & Description \\
\hline \multirow[t]{3}{*}{ I NDEMENU } & (Located in celis Y63..AD64) & $\begin{array}{l}\text { Custom menu INDEMEN! } \\
\text { allows the user to } \\
\text { select one of five } \\
\text { possible independent } \\
\text { variables for } \\
\text { sensitivity analyses. } \\
\text { It is called only from } \\
\text { the SENSMENU menu. }\end{array}$ \\
\hline & 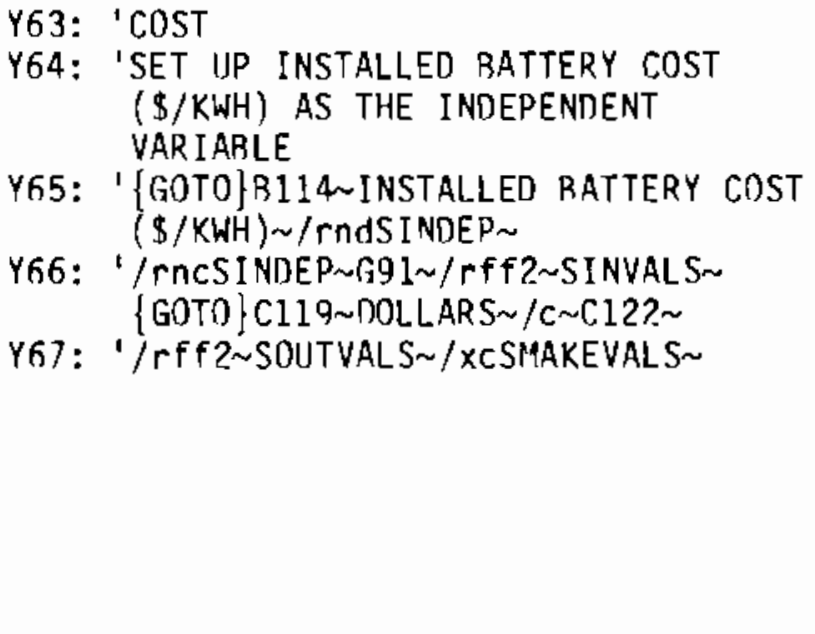 & $\begin{array}{l}\text { Writes 'Installed Bat- } \\
\text { tery Cost (\$/KWH)' as } \\
\text { the independent vari- } \\
\text { able name, deletes and } \\
\text { recreates range SINDEP } \\
\text { indicating the vari- } \\
\text { able's original loca- } \\
\text { tion in the spread- } \\
\text { sheet, formats the cells } \\
\text { containing independent } \\
\text { variable values, writes } \\
\text { labels indicating that } \\
\text { they are to he entered } \\
\text { in dollars, then calls } \\
\text { subroutine SMAKEVALS. }\end{array}$ \\
\hline & 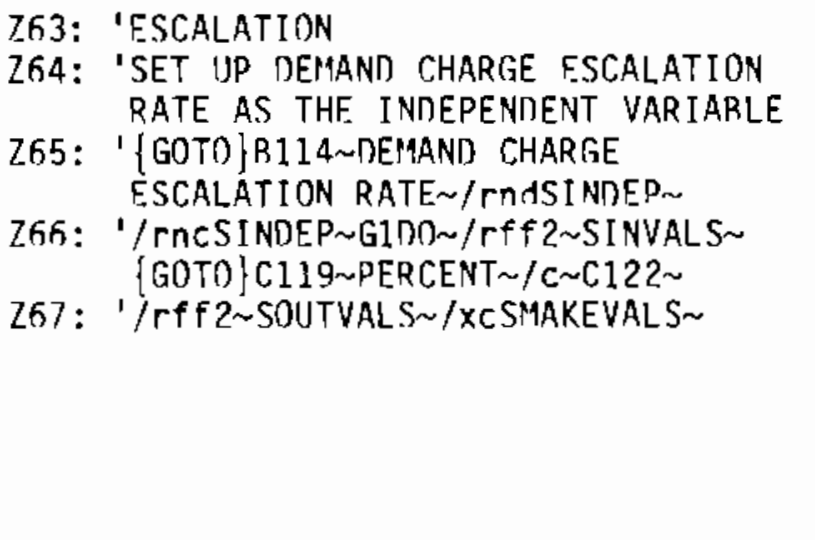 & $\begin{array}{l}\text { Writes 'nemand Charge } \\
\text { Escalation Rate' as the } \\
\text { independent variable } \\
\text { name, deletes and recre- } \\
\text { ates the range SINDFP, } \\
\text { formats the cells con- } \\
\text { taining independent } \\
\text { variable values, writes } \\
\text { labels indicating that } \\
\text { they are to he entered } \\
\text { as percentages, then } \\
\text { calls subroutine } \\
\text { SMAKEVALS. }\end{array}$ \\
\hline
\end{tabular}


TABLE C.4. Contd

\begin{tabular}{|c|c|}
\hline $\begin{array}{l}\text { Range } \\
\text { Name }\end{array}$ & Macro \\
\hline & 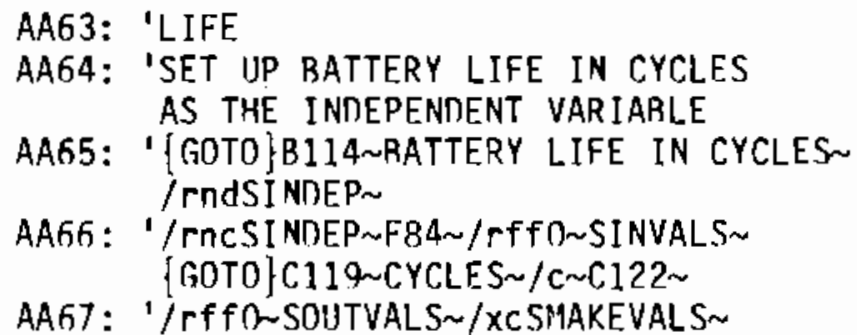 \\
\hline
\end{tabular}

AC63: 'RNDTRIP

AC64: 'SET UP ROIND TRIP CONVERTER EFFICI ENCY AS THE INDEPENNENT VARIABLE

AC65: ' $\{$ GDTO $\}$ B114 ROUNN TRIP CONVERTER EFFICIENCY / rndSINDEP $\sim$

AC66: $1 /$ rnCSINDEP F87 / rff? $\sim$ SINVALS $\sim$

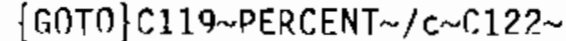

AC67: $1 / \mathrm{rff} ? \sim$ SOUTVAL.S $/$ XCSMAKEVALS $\sim$
An63: 'OIIT

AD64: 'RETURN TO PREVIOUS MENU AD65: ' [GOTO $A 109 \sim / X m S E N S M E N(\} \sim$
Description

Writes 'Battery Life in Cycles' as the independent variable name, deletes and recreates the range SINNEP, formats the cells containing independent variable values, writes labels indicating that they are to be entered in cycles, then calls suhroutine SMAKEVALS.

Writes 'Federal Tax Rate' as the independent variable name, deletes and recreates the range SINDEP, formats the cells containing independent variable values, writes labels indicating that they are to he entered as percentages, then calls subroutine SMAKEVALS.

Writes 'Round Trip Converter Efficiency' as the independent variable name, deletes and recreates the range SINNEP, formats the cells containing independent variable values, writes labels indicating that they are to he entered in percentages, then calls subroutine SMAKEVALS.

Returns the user to the SENSMENII custom menu, thus allowing sensitivity analysis results to he calculated. 
TABLE C.4. Contd

Range

Name

Macro

Description

SMAKEVALS W62: 'SURROUTINE SMAKEVALS CALLEN FROM INDEMENU OPTIONS

This subroutine is called hy each of the

W63: 'PRESS RETURN TO ENTER MIN, MAX VALLIES, ESCAPE (ESC) WHEN DONE \{?\}\{ESC

W64: '/riA1 15 . B128 \{G0T0\}E118 +B119 (CALC)

$\{$ DOWN $\}+B 119+(B 122-B 119) \star 0.25$

W65: ' CALC $\{$ DOWN $\}+B 119+(B 122-B 119) \star n .5$ (CALC), DOWN\}

W66: '+B119+(B122-B119)*0.75\{CALC $\}\{$ DOWN $\}+$ B122 \{CALC\}

W67: 'ALL DONF! ! .PRESS RETURN, CHOOSE

'OUIT' OPTION THEN 'RUN' OPTION $\{$ ? \} ESC

W68: '\{GOTO $\}$ A109 / XmINDEMENIJ

INDEMENII options used to specify an independent variable. It begins hy displaying a message and allowing input of minimum and maximum values for the chosen independent variable. It then copies them into the sensitivity analysis table, computes three intermediate values, displays a message and returns to INDEMENIJ. 
TABLE C.5. Description of Named Ranges

\begin{tabular}{|c|c|c|}
\hline $\begin{array}{l}\text { Range } \\
\text { Name }\end{array}$ & Location & Description \\
\hline SINDEP & Varies & $\begin{array}{l}\text { This range is deleted and created each time that an } \\
\text { independent variable is set up for sensitivity } \\
\text { analys is from SENSMENU. If battery cost is spe- } \\
\text { cified, the range location will be cell G9l; the } \\
\text { range location will be cell F100 for demand charge } \\
\text { escalation rate and cell F84 for battery life. } \\
\text { Cell F87 is used for round trip converter effi- } \\
\text { ciency; cell G106 if federal tax rate is chosen as } \\
\text { the independent variable. }\end{array}$ \\
\hline SINVALS & $B 119 . . B 122$ & $\begin{array}{l}\text { This range includes the minimum and maximum values } \\
\text { for the chosen independent variable that are } \\
\text { entered by the user. }\end{array}$ \\
\hline SOUTVALS & F118..E122 & $\begin{array}{l}\text { This range encompasses the five values of the } \\
\text { independent variable which appear in the left } \\
\text { column of the sensitivity analysis table. }\end{array}$ \\
\hline STABLE & F117 ..G122 & $\begin{array}{l}\text { This range is the scope of the sensitivity analysis } \\
\text { table computed hy SENSMENU option RUN. }\end{array}$ \\
\hline STITLE & B114 & $\begin{array}{l}\text { This cell contains the name of the independent } \\
\text { variable currently heing used for sensitivity } \\
\text { analyses. Used in the PPSENS and PWSENS graphs. }\end{array}$ \\
\hline SUNITS & C119 & $\begin{array}{l}\text { This cell contains the name of the unit being used } \\
\text { to describe values of the independent variable } \\
\text { currently in use for sensitivity analyses. Used in } \\
\text { the PPSENS and PWSENS graphs. }\end{array}$ \\
\hline
\end{tabular}




\section{.}


No. of

Copies

OFFSITE

$10 \mathrm{Mr} . \mathrm{J}$. Quinn

U.S. Department of Energy

Forrestal Building, RM 6A049

1000 Independence Ave., SW

Washington, DC 20585

5 Dr. A. R. Landgrebe

U.S. Department of Energy

CE-141, MS 5 E-036

Forrestal Building

1000 Independence Ave., SW

Washington, DC 20585

30 DoE Technical Information

Center

John B. Barclay

Manager, Product Development

St. Joe Minerals Corp.

Monaca, PA 15061

Ken Caraway

Supervising Design Engineer

Duke Power Company

P.0. Box 33189

Charlotte, NC 28242

Bart Chezar

Senior Engineer

New York Power Authority

10 Columbus Circle

New York, NY 10019

John L. Del Monaco, P.E.

Public Service Electric and Gas Co.

80 Park Plaza

P.0. $80 \times 570$

Newark, NJ 07101
No. of

Copies

Steve Eckroad

Bechtel

P.0. Box 2965

Mail Stop 50/4/C19

San Francisco, CA 94119

Fred Ellis

Southern Company Services

P.0. Box 2625

Birmingham, AL 35202

Donald A. Fagnan, P.E.

Research and Planning Div.

Philadelphia Electric Co.

2301 Market St. (S10-1)

Philadelphia, PA 19101

David 0. Feder, Ph.D.

25 Ridgedale Ave.

Madison, NJ 07940

Vern Feiste

Electrical Engr. Dept.

Southern Illinois Univ.

Carbondale, IL 62901

Robert H. Fri

Energy Transition Corp.

1101 Connecticut Ave., NW

Washington, DC 20036

Mr. Gibstine

Product Marketing Manager

Delco Remy

2401 Columbus Ave

Anderson, IN 46018

Dan Hart

FPL

P.0. Box 029100

Miami, FL 33102

Sam Hashemi

Potomal Electric Power Co.

1900 Penn. Ave. NW

Washington, DC 20068 
No. of

Copies

L. Jackson

Lockheed

Organizational \#90-20

Building 201

3251 Hanover Street

Palo Alto, CA 94304

George T. Jacobi

Johnson Controls, Inc.

5757 N. Green Bay Ave.

Milwaukee, WI 53201

W. 0. Jentry

Johnson Controls, Inc.

5757 N. Green Bay Ave.

Milwaukee, WI 53201

Robert L. Mauro

RPM

1101 St. Paul, Suite 302

Baltimore, M0 21202

John Mills

Firing Circuits

Muller Avenue

Norwalk, CT 06852

Kevin D. Murphy

Storage Batteries Div. 2525

Sandia National Labs.

Albuquerque, NM 87185

Roger Shroeder

Burns and McDonnell

P.0. Box 173

Kansas City, M0 64141

William E. Schulte

Omaha Public Power District

1623 Harney St.

Omaha, NB 68102

Reuben Steinberg

System Planning Department

P.0. $80 \times 570$

Newark, NJ 07101
No. of

Copies

Fred Strnisa

New York State ERDA

Agency Building No. 2

Empire State Plaza

Albany, NY 12223

William Tiedemann

Johnson Controls, Inc.

P.0. Box 591

Milwaukee, WI 53201

Brian J. Winters, P.E.

Director, Systems Engineering

2129 North Coast Highway

P.0. Box 1126

Newport, OR 97365-1795

ONSITE

DOE-Richl and Operations

D. R. Segna

20 Pacific Northwest Laboratory

W. B. Ashton

D. R. Brown

D. C. Debrodt

R. M. Fleischman

C. J. Hostick (6)

J. W. Hurwitch

R. A. Hutchinson

C. H. Imhoff

C. Winter

Publishing Coordination MH (2)

Technical Information (5) 